NBER WORKING PAPER SERIES

\title{
SHORT-RUN PAIN, LONG-RUN GAIN: THE EFFECTS OF FINANCIAL LIBERALIZATION
}

\author{
Graciela L. Kaminsky \\ Sergio L. Schmukler \\ Working Paper 9787 \\ http://www.nber.org/papers/w9787 \\ NATIONAL BUREAU OF ECONOMIC RESEARCH \\ 1050 Massachusetts Avenue \\ Cambridge, MA 02138 \\ June 2003
}

We have received insightful comments from Tom Glaessner, Gian Maria Milesi-Ferretti, Raghu Rajan, and Linda Tesar, as well as participants at presentations held at the American Economic Association 2002 Meeting, the Deutsche Bundesbank, the Federal Reserve Bank of New York, the Federal Reserve Board, the International Monetary Fund, the Society for Economic Dynamics 2002 Meeting (New York University), the LACEA 2002 Meeting (Madrid), Stanford University, and the World Bank. We are grateful to Tatiana Didier, Federico Guerrero, Cicilia Harun, José Pineda, Arun Sharma, Akiko Terada, Francisco Vazquez, Chris van Klaveren, and Kevin Wang, who helped us with excellent research assistance at different stages of the project. This paper has been previously circulated under the title "On Booms and Crashes: Financial Liberalization and Stock Market Cycles." The Research Committee and the Latin American Regional Studies Program of the World Bank kindly provided financial support. The views expressed in this paper are those of the authors and should not be interpreted as reflecting those of the World Bank. The views expressed herein are those of the authors and not necessarily those of the National Bureau of Economic Research.

C2003 by Graciela L. Kaminsky and Sergio L. Schmukler. All rights reserved. Short sections of text not to exceed two paragraphs, may be quoted without explicit permission provided that full credit including (C) notice, is given to the source. 
Short-Run Pain, Long-Run Gain: The Effects of Financial Liberalization Graciela L. Kaminsky and Sergio L. Schmukler

NBER Working Paper No. 9787

June 2003

JEL No. F30, F32, F33, F34, G12, G15

\begin{abstract}
We examine the short- and long-run effects of financial liberalization on capital markets. To do so, we construct a new comprehensive chronology of financial liberalization in 28 mature and emerging economies since 1973. We also construct an algorithm to identify booms and busts in stock market prices. Our results indicate that financial liberalization is followed by more pronounced boom-bust cycles in the short run. However, financial liberalization leads to more stable markets in the long run. Finally, we analyze the sequencing of liberalization and institutional reforms to understand the contrasting short- and long-run effects of liberalization.
\end{abstract}

Graciela L. Kaminsky

Department of Economics

George Washington University

Washington, DC 20052

and NBER

graciela@gwu.edu

Sergio Schmukler

World Bank

Washington, DC 20433

sschmukler@worldbank.org 


\section{Introduction}

The crises of the 1990s have claimed several victims. Banking systems in many countries collapsed, roaring growing economies suddenly faced sharp recessions, and the booming international capital flows of the mid 1990s dwindled to a trickle. This is not all. Another important casualty of these crises has been the support for the liberalization of financial systems. In the aftermath of the Asian crisis, many have argued that globalization has gone too far, leading to erratic capital markets and causing costly crises. This has prompted some to suggest a return to the old order of financial controls. For example, Stiglitz (1999) clamors for developing countries to put some limits on capital inflows to moderate "excessive" boom-bust patterns in financial markets. ${ }^{1}$ Even controls on capital outflows, not long ago dismissed as ineffective, have been recommended again. Krugman (1998), for example, argues that capital controls might help in managing, at least temporarily, an otherwise disorderly retreat of investors. Rodrik (1998) and (2000) argues that financial liberalization can lead to financial crashes and that capital controls might be beneficial given the boom-bust nature of capital flows. The debate has reached the general public, with Soros (2002) and Stiglitz (2002) broadly criticizing the functioning of the international financial system. With many economists supporting intervention in financial markets, long gone seem to be the days of an indiscriminate advocacy of financial integration. ${ }^{2}$

Interestingly, in what seems to be a parallel world, many still praise the advantages of liberalization. It is claimed that financial liberalization helps to improve the functioning of financial systems, increasing the availability of funds and allowing cross-country risk diversification. For example, Obstfeld (1998) argues that international capital markets can channel world savings to their most productive uses, irrespective of location. Stulz (1999) and Mishkin (2001) claim that financial liberalization promotes transparency and accountability, reducing adverse selection and moral hazard while alleviating liquidity problems in financial markets. They argue, moreover, that international capital markets help to discipline policymakers, who might be tempted to exploit an otherwise captive domestic capital market.

\footnotetext{
${ }^{1}$ These overreactions in capital markets are often explained by information asymmetries. With imperfect and costly information, investors may act as a herd and overreact to shocks, withdrawing from countries at the smallest signs of problems, even when fundamentals do not warrant it. See, for example, Calvo and Mendoza (2000).

${ }^{2}$ See, for example, Eichengreen and Wyplosz (1993) and Wyplosz (2001).
} 
Others even claim that financial liberalization and the financial development it triggers tend to greatly facilitate economic growth. ${ }^{3}$ As with the group that favors more repression, the group supporting deregulation has also been growing in numbers. ${ }^{4}$

The empirical research, so far, has not helped to resolve the conflicting views. The findings in the crisis literature suggest that excessive booms and busts in financial markets are at the core of currency crises and that these large cycles are triggered by financial deregulation. ${ }^{5}$ On the contrary, the findings in the finance literature tend to support the claim that deregulation is beneficial, with liberalization reducing the cost of capital. ${ }^{6}$ Perhaps, the inability to settle this debate is due to the fact that the various lines of empirical research focus either on the short-run or on the long-run effects of deregulation, without studying the possible time-varying effects of financial liberalization. Moreover, the existing empirical literature has not provided a comprehensive analysis of the liberalization process. It has concentrated alternatively on the liberalization of the domestic financial sector, the capital account, or the stock market, even when liberalization reforms have entailed the progressive opening of the three sectors.

The goal of this paper is, first, to provide a better understanding of the liberalization process and, second, to explain both the link between liberalization and crises as well as the relation between deregulation and more stable financial markets. To do so, we first assemble a new, more comprehensive database on financial liberalization for 28 countries for the period January 1973-June 1999. By itself, this is an important contribution because this database improves over the existing ones in several respects. First, the new dataset looks at the experiences of a wide set of countries, both developed and developing. Second, it captures with a similar framework various aspects of liberalization, namely the deregulation of the capital account, the domestic financial sector, and the stock market. Third, the chronology covers an extended period in which several regulatory changes occurred, including deregulations and impositions of new controls. Fourth, the new data provide information on the degrees of liberalization.

\footnotetext{
${ }^{3}$ The evidence on the benefits of financial deregulation seems to be quite strong with, for example, output growth rates estimated to have increased about one percentage point following liberalization (as shown in Bekaert, Harvey, and Lundblad 2001).

${ }^{4}$ See, for example, King and Levine (1993), Jayaratne and Strahan (1996), Rajan and Zingales (1998), and Levine (2001).

${ }^{5}$ See, for example, Corsetti, Roubini, and Pesenti (1998), McKinnon and Pill (1997), Kaminsky and Reinhart (1999), and Schneider and Tornell (2001).

${ }^{6}$ See, for example, Henry (2000).
} 
We also construct an anatomy of stock market cycles by applying algorithms designed to identify business cycles. With this technique, we study the duration and magnitude of upturns and downturns. Since financial cycles would be spurious if markets were efficient, we test the null hypothesis of a random walk. ${ }^{7}$ We then study whether booms and busts change with financial liberalization. Though financial liberalization is expected to affect different parts of the financial system, we find it useful to concentrate on stock market fluctuations. First, stock market prices are one of the few financial variables for which one can obtain meaningful long time series across countries. Thus, the time span of these data allows us to analyze the effects of financial liberalization. Second, the finance literature has extensively study the behavior of world stock market prices, providing a benchmark for our results. We finally analyze the possibility that financial deregulation triggers forces that favor changes in institutions, which can ultimately promote financial stability and growth.

The rest of the paper is organized as follows. Section II describes the new data on financial liberalization and examines the patterns of deregulation. Section III characterizes booms and busts in the different regions. Section IV examines whether domestic financial liberalization and capital controls can explain the changing nature of financial cycles. Section V relates financial liberalization to institutional reform. Section VI concludes.

\section{The Evolution of Global Financial Liberalization}

One of the most prolific areas of empirical research in international economics and finance has been that of the analysis of the effects of controls and financial liberalization on financial markets, investment, and growth. Surprisingly, in spite of the great interest of several disciplines on the effects of deregulation of financial markets, the information on the evolution of financial regulations is still very fragmented. Below is a brief review of the existing measures.

\footnotetext{
${ }^{7}$ Some empirical evidence in the last two decades has undermined the belief in efficient markets. Now many economists believe that imperfections in asset markets trigger bubbles and protracted and predictable bull and bear markets. See for example, De Long, Shleifer, Summers, and Waldmann (1990), Allen and Gorton (1993), and Allen, Morris, and Postlewaite (1993).
} 
Information on capital account controls is mostly based on indicators published by the International Monetary Fund (IMF) in Exchange Arrangements and Exchange Restrictions. ${ }^{8}$ For the period 1975-1995, this publication reports a single indicator classifying only two capital account regimes: a "no controls" regime, which includes episodes with full liberalization of the capital account, and a "controls" regime, which includes both episodes with minor restrictions to the free flow of capital as well as episodes with outright prohibition of all capital account transactions. This indicator does not distinguish between controls on capital inflows and controls on capital outflows. Only in 1996, the IMF began to publish a more comprehensive report on capital account controls, which still does not capture the intensity of controls. ${ }^{9}$

Information on regulations of the domestic financial sector is even more fragmented. There is no institution compiling systematic cross-country information over time and researchers have relied on varied sources. One of them is Williamson and Mahar (1998), which dates liberalization according to five distinct dimensions of financial liberalization: existence of credit controls, controls on interest rates, entry barriers to the banking industry, government regulation of the banking sector, and importance of government-owned banks in the financial system. Most researchers construct their own liberalization chronology. For example, Demirguc-Kunt and Detragiache (1999) date liberalization for 53 countries since 1980. In that study, liberalization of the domestic financial sector is interpreted as liberalization of domestic interest rates.

Information on the liberalization of domestic stock markets is also still quite partial. The International Financial Corporation (IFC) provides this information just for emerging markets. Again, this index (as the IMF index for the capital account) only captures two regimes: a "liberalization" regime and a "restricted" regime. The liberalization dates are determined based on whether foreigners are allowed to purchase shares of listed companies in the domestic stock exchange and whether there is free repatriation of capital and remittance of dividends and capital gains. Others, such as Bekaert and Harvey (2000), construct their own chronologies of stock market liberalization to date liberalization episodes for emerging markets, using information

\footnotetext{
${ }^{8}$ See Quinn and Inclan (1997) for an alternative measure.

${ }^{9}$ The new indicators evaluate restrictions on 11 types of capital account transactions: (1) capital market securities, (2) money market instruments, (3) collective investment securities, (4) derivatives and other instruments, (5) commercial credits, (6) financial credits, (7) guarantees, sureties, and financial backup facilities, (8) direct investment, (9) liquidation of direct investment, (10) real estate transactions, and (11) personal capital movements.
} 
compiled by the IFC and the establishment of new investment vehicles like country funds and depositary receipts. ${ }^{10}$

The existing chronologies share some limitations. One limitation is that they do not distinguish between different intensities of liberalization/repression. Since deregulation tends to change slowly, valuable information is lost when the indicators only try to assess whether or not the liberalization has occurred. ${ }^{11}$ Another limitation is that most chronologies analyze financial liberalization episodes as if they were permanent. Still, many countries have undergone several liberalization reversals, particularly following currency crises. ${ }^{12}$ Naturally, these limitations call for a more comprehensive analysis of the various aspects of financial controls.

\section{A. New Measures of Financial Liberalization}

The new measures of financial liberalization introduced in this paper try to overcome part of the shortcomings of previous chronologies discussed above. Thus, our database captures to some degree the intensity of financial liberalization episodes as well as episodes of liberalization reversals. Our chronology also tries to address some of the limitations of the empirical research on the effects of financial liberalization. First, most of the empirical research focuses on emerging markets, perhaps because most concerns are associated with liberalization episodes in developing countries, with even the most averse critics of capital account liberalization still supporting the financial deregulation of mature markets. A comprehensive picture of the effects of financial liberalization requires the analysis of deregulation episodes in both developed and developing countries, which the new database covers. Second, most of the previous studies focus on the elimination of controls on just one particular financial sector, be it the capital

\footnotetext{
${ }^{10}$ There is a very large related literature that studies the extent of financial and economic integration from observable economic variables, not from government regulations. See, for example, Frankel (2000), Obstfeld and Rogoff (2001), Edison and Warnock (2002), and Obstfeld and Taylor (2002).

${ }^{11}$ For example, Chile introduces restrictions on capital inflows at the beginning of the 1990s. Controls are reinforced in the mid-1990s in the midst of the capital inflow episode. In 1998, under the threat of a contagious speculative attack against the Chilean peso, controls are eliminated. Similarly, domestic financial deregulation may take several years to be complete. For example, the deregulation of the domestic banking sector in Colombia is initiated in August 1974. Only in the 1980s, credit controls are finally eliminated.

${ }^{12}$ For example, Argentina implements a broad liberalization of financial markets in 1977, which is later reversed in 1982. Again, in the late 1980s, a new wave of financial liberalization affects the domestic financial sector, the capital account, and the stock market. This time around the liberalization attempt is longer lasting. Still, again in 2001, in the midst of Argentina's crisis, the government reintroduces controls on interest rates and restrictions on capital account transactions.
} 
account, the domestic financial sector, and the stock market. This focus on the opening of just one financial market may result in a biased picture, since controls in one sector can also affect the behavior of other parts of the financial system, which may or may not be directly under any type of restrictions. ${ }^{13}$ The new chronology deals with the regulations in three sectors.

The new database includes 28 countries for the period 1973-1999. ${ }^{14}$ We classify the sample into four (mostly regional) country groupings: the G-7 countries, which are comprised of Canada, France, Germany, Italy, Japan, United Kingdom, and the United States; the Asian region, which includes Hong Kong, Indonesia, Malaysia, the Philippines, (South) Korea, Taiwan, and Thailand; the European group, which excludes those countries that are part of the G-7, and includes Denmark, Finland, Ireland, Norway, Portugal, Spain, and Sweden; and the Latin American sample, which consists of the largest economies in the region, Argentina, Brazil, Chile, Colombia, Mexico, Peru, and Venezuela. We work with these countries due to the availability of rich data covering both their processes of financial liberalization and the long run behavior of their stock markets. ${ }^{15}$

To capture the liberalization of the capital account, we evaluate the regulations on offshore borrowing by domestic financial institutions, offshore borrowing by non-financial corporations, multiple exchange rate markets, and controls on capital outflows. The first two indicators reflect restrictions on capital inflows. Restrictions on capital inflows can take various forms, with the most extreme restriction being an outright prohibition to borrow overseas. Milder controls include restrictions of minimum maturity on capital inflows and non-interest reserve requirements on foreign borrowing.

To measure the liberalization of the domestic financial system, we analyze the regulations on deposit interest rates, lending interest rates, allocation of credit, and foreign-

\footnotetext{
13 This problem may be particularly important because the complete deregulation of financial systems is not accomplished in just one round, and the time span between the deregulation of one market and the elimination of controls across the board takes, in most cases, several years. For example, the data show that, in the 1970s, domestic financial repression is widespread not only in emerging markets, but also in several mature financial markets. Governments start lifting the various restrictions gradually. In many cases, the liberalization reform starts in the banking sector with the deregulation of domestic interest rates. The elimination of interest rate controls not only affects the market for bank loans and deposits, but also attracts international capital flows (when these flows are not strictly prohibited). Also, the stock market flourishes as the extent of credit rationing diminishes.

${ }^{14}$ In fact, since Hong Kong and Taiwan are part of China, the database has fewer countries. Still, for simplicity we refer to those economies as countries.

${ }^{15}$ Other possible countries were not included in the dataset to make the study feasible, in light of the large amount of work needed to collect all the data. Nevertheless, we believe that no particular selection bias was introduced in the process of choosing the countries.
} 
currency deposits. As additional information, we also collect data on reserve requirements. To set the liberalization dates, we focus mainly on the first two variables, the price indicators. However, we complement that information with the regulations on the last three variables, those on quantities, to have a better picture of the degree of repression of the domestic financial sector. Finally, to track the liberalization of stock markets, we study the evolution of regulations on the acquisition of shares in the domestic stock market by foreigners, repatriation of capital, and repatriation of interest and dividends.

For each sector, the chronology identifies three regimes: "fully liberalized," "partially liberalized," and "repressed." The criteria used to determine whether the capital account, the domestic financial sector, and the stock market are fully or partially liberalized, or repressed, are described in detail in Appendix Table 1. We established these criteria after collecting all the regulations and carefully studying the range of restrictions adopted throughout countries and years. We believe that these criteria characterize well the degrees of financial liberalization. The chronology of restrictions compiled for each country and sector are described in Annex Table 1. The complete list of references used to construct the chronology is reported in Annex Table $2 .^{16}$

Table 1 reports the dates of partial and full financial liberalization for all the countries in the sample. The first three columns of dates display the liberalization of the capital account, the domestic financial sector, and the stock market. The last two columns report dates of partial and full liberalization taking into account the three sectors analyzed. A country is considered to be fully liberalized when at least two sectors are fully liberalized and the third one is partially liberalized. A country is classified as partially liberalized when at least two sectors are partially liberalized.

\section{B. Pace and Dynamics of Liberalization}

Figures 1-3 and Table 2 summarize the information in Table 1 by displaying the timeseries and cross-sectional variation of liberalization. Figure 1 plots the index of financial

\footnotetext{
${ }^{16}$ The sources of information include the IMF publications Exchange Rate Arrangements and Restrictions and Recent Economic Developments (country reports), the IFC publication Emerging Markets Database, and the Organization for Economic Cooperation and Development (OECD) publication Economic Surveys. We also use
} 
liberalization in emerging and mature markets. This index jointly evaluates the liberalization of the capital account, the domestic financial sector, and the stock market. It can take values between one and three, with one indicating fully liberalized and three indicating fully repressed financial systems. As expected, mature financial markets are on average less regulated. The index for mature markets averages 1.7 over the sample, while for emerging markets, it averages 2.3. Interestingly, across all regions there is a gradual lifting of restrictions, with the index of liberalization declining from an initial value of 2.5 for mature markets and 2.9 for emerging economies to one and 1.2, respectively, toward the end of the sample. Still, there is also a regional pattern in the dynamics of financial liberalization, with emerging markets suffering liberalization reversals in the early 1980s, following the debt crisis. In contrast, the pace of liberalization in mature markets, while also gradual, is uninterrupted.

Figures 2 and 3 examine separately the sequencing of liberalization of the capital account, the domestic financial sector, and the stock market. Figure 2 shows the index of liberalization for each sector for both emerging and mature markets. Stock markets in developed countries are liberalized earlier, with the index for this sector oscillating around 1.5 in the early 1970s. In contrast, both the domestic financial sector and the capital account tend to be severely repressed until the early 1980s. In the early 1970s, the indexes for both sectors are on average above 2.5. Financial markets across the board are heavily repressed in developing countries in the early 1970s. But in the mid and late 1970s, many emerging economies liberalize the domestic sector and the capital account. The liberalization reform is short-lived. Controls are re-imposed in the aftermath of the 1982 debt crisis. Overall, restrictions in stock markets remain in place until the late 1980s when a liberalization wave occurs in Asia and Latin America.

While Figure 2 provides information on the average level of restrictions in the various financial markets in the two regions, it may still mask individual country experiences. For example, a medium value of the index in one region may reflect that all the countries in that region are partially liberalized, or that some countries are fully liberalized while the rest of the countries are completely repressed. Figure 3 presents another perspective of the sequencing of liberalization across countries. This figure reports the proportion of countries with (at least) partial liberalization of the capital account, the domestic financial sector, and the stock market,

various reports by the Economist's Intelligence Unit, the World Bank, annual reports of central banks, as well as research papers with chronologies on financial market restrictions. 
again examined separately for emerging markets and mature markets. By the early 1970s, about 80 percent of stock markets in mature markets are already liberalized. In mature markets, the liberalization of the domestic financial sector also predates the opening of the capital account, with about all countries liberalizing, at least partially, the domestic financial sector by the mid 1980s. It is only in the late 1980s and the beginning of the 1990s, in part driven by the movement toward the formation of the European Monetary Union, that capital account liberalization reaches all mature markets.

Liberalization follows a different path in emerging markets. Only a small proportion of countries implement reforms before the early 1970s. This proportion increases in the late 1970s and then again in the mid and late 1980s. By early 1990s, all the sectors of the financial system are finally liberalized. There are two episodes of financial liberalization. The first one is in the late 1970s. In this episode, all the action centers in the domestic sector and the capital account, with the stock market continuing to be out of the reach for foreign investors. This liberalization episode ends following the debt crisis in 1982. The second wave of liberalization starts in the late 1980s. This time around, basically both the domestic sector and the stock market are jointly deregulated, predating capital account liberalization that only starts in the early 1990s.

Table 2 examines even further the sequencing of liberalization by analyzing the strategies and duration of liberalizations in Asia, Europe, G-7 countries, and Latin America. The top two panels show the proportion of episodes in which the capital account, the domestic financial sector, or the stock market is liberalized first. The top panel focuses on partial liberalization episodes, the panel below examines full liberalization episodes. The bottom two panels display the duration of liberalization episodes; they report the number of months from the time the first market is deregulated until liberalization is implemented in all markets. The top two panels reveal that the paths toward financial reform differ across regions. Basically all the G-7 countries deregulate the stock market first. European countries implement a somewhat mixed strategy toward deregulation, with 25 percent of the countries liberalizing the domestic financial sector first and basically all the rest deregulating the stock market first. On the other hand, Latin American countries overwhelmingly adopt liberalization of the domestic financial sector first, while Asian countries follow a mixed strategy, with some countries opting for deregulating the domestic sector first and some others focusing on the stock market first. Capital account liberalization in all Asian countries is mostly introduced at a latter stage. 
The bottom panels reveal that liberalization reforms take a long time to be completed. On average, 66 months elapse from the time the first market is liberalized until all markets are deregulated. Interestingly, the time to completion of the liberalization reform is far longer in Asia than in Latin America. Finally, liberalization episodes that are first implemented in the stock market are the ones that become completed the fastest. The variety of experiences in financial reforms indicates that it is important to examine not just the responses to liberalization in one particular financial market, but that it is important to examine the effects of the sequencing of the deregulation reform.

\section{Financial cycles}

As discussed above, to understand better the conflicting stylized evidence on the effects of financial liberalization, it is useful to study the short- and long-run response of financial markets to deregulation. This section sets the groundwork to reconcile the evidence by constructing an anatomy of booms and busts (crashes) in stock markets.

\section{A. Methodology for Identifying Financial Cycles}

There is a long tradition in macroeconomics in analyzing economic fluctuations in terms of business-cycle phases. Economists have examined the behavior of output in expansions and recessions, with particular attention to asymmetries in the two phases and to the possible changing nature of those fluctuations. For the United States, there is also an "official" classification of the cycle in expansions and contractions. No similar interest has flourished in characterizing boom-bust cycles in financial markets. Most studies in financial markets are focused on examining the relation between dividends, interest rates, and stock prices to evaluate whether markets are efficient. Other papers analyze the time-varying volatility in financial markets using ARCH-GARCH models. A third line of research looks at the domestic and global factors that influence prices. ${ }^{17}$ In contrast, there seem to be no studies on the behavior of stock prices over financial cycles. This lack of evidence on the amplitude and duration of booms and

\footnotetext{
${ }^{17}$ For a review see, for example, Karolyi and Stulz (2002).
} 
busts seems particularly notable in light of the evidence that links booms and busts in credit and asset prices with financial crises.

Perhaps, the lack of interest in booms and busts in stock prices steams from the idea that in efficient markets prices should follow random walk processes. In this case, cycles are meaningless. However, the interest in booms and busts in international financial markets has been growing, following the performance of stock markets in recent years. ${ }^{18}$ Also, as Cecchetti, Lam, and Mark (1990) show, even in efficient markets stock prices can follow mean-reverting processes, with cycles in the stock market replicating cycles in output. Moreover, cycles could be magnified by the increasing presence of institutional investors, which tend to follow momentum-based fads (buying stocks that are past winners and selling past losers), and by the presence of asymmetric information that leads to herding. ${ }^{19}$

This paper concentrates on the fluctuations of stock prices without trying to quantify the possible imperfections in financial markets. The latter would not be an easy task due to the lack of agreement about the empirical counterpart to any definition of equilibrium stock prices. However, while we do not isolate the effects of fundamentals and fads on financial cycles, the characterization of stock market cycles will allow us to start understanding the behavior of financial markets. In particular, we will be able to have a reading on whether financial liberalization has magnified the boom-bust cycles in financial markets.

The question now is how to identify historical cycles in stock prices. There is no general agreement on the techniques to isolate fluctuations of variables at business cycles frequencies. The first approach was that pioneered by researchers at the National Bureau of Economic Research (NBER). ${ }^{20}$ The business cycle turning points were identified retrospectively and on an ongoing basis by the NBER. Although initially these turning points were determined judgmentally, the process can be well approximated by a computer algorithm developed by Bry and Boschan (1971). The NBER continues to use this methodology to identify what has become to be known as the official business cycles dating in the United States. ${ }^{21}$

\footnotetext{
${ }^{18}$ See, for example, Tornell and Westermann (2002) and Ventura (2002).

${ }^{19}$ See, for example, Grinblatt, Titman, and Wermers (1995).

${ }^{20}$ These researchers include Mitchell (1927), Mitchell and Burns (1938), and Burns and Mitchell (1946).

${ }^{21}$ Other researchers of the business cycle have used linear filters to distinguish between the trend and cyclical components of time series. However, there has not been any agreement on whether variables are trend stationary or difference stationary or what is the best filter to isolate the fluctuations at different frequencies. As examined in Stock and Watson (1998), these considerations have led econometricians to find methods that better isolate the
} 
In this paper, we follow the approach used by the NBER to construct an algorithm that identifies turning points. We examine stock market fluctuations at intermediate frequencies, since financial crises tend to follow boom-bust cycles in financial markets of an intermediate duration, between two and three years. According to Bry and Boschan (1971), the first step in the determination of cycles is the identification of cyclical turning points. This technique and the algorithms that we apply look for clearly defined swings in stock market prices in each country. We work with the same order of duration as business cycles, that is swings that are longer than two years. This is the only identifying restriction. We are not imposing any other restrictions such as minimum amplitude of cycles. Essentially, the algorithm isolates local minima and maxima in a time series, subject to the constraint that the duration of upturns and downturns cannot be less than 12 months. ${ }^{22}$

The cycles we identify would be spurious if stock prices followed random walk processes. However, there are a number of papers that argue that the null hypothesis of random walk can be rejected in both developed and developing countries, though the debate is still open. $^{23}$ Here, we confirm that conclusion using our methodology, which provides evidence that the random walk does not capture the basic properties of our data on stock prices. To do so, we estimate random walks with drift using parameters calculated from the actual data. For each country, we simulate a specific model 1,000 times. Since some of the series on stock prices do not span the whole sample, the number of months for each country simulation is the same as the number of months in the actual data. We then filter the simulated data with the algorithm and compare the cycles generated by random walk processes and those generated by the actual data.

\section{B. Empirical regularities}

Figure 4 reports monthly log stock price indexes for the 28 countries in the sample. Stock prices are measured in 1993 U.S. dollars (Appendix Table 2 reports the indexes used as

cyclical component of economic time series with some researches proposing using the Hodrik-Prescott (1997) filter and others arguing in favor of the Baxter and King's (1995) band-pass filter.

${ }^{22}$ The algorithm dates contractions and expansions using each country's stock price series, rather than the detrended series. Therefore, busts correspond to sequences of absolute declines in stock prices rather than periods of slow growth relative to the trend.

${ }^{23}$ See, for example, Fama and French (1988), Lo and MacKinlay (1988), Poterba and Summers (1988), Frennberg and Hansson (1993), and Urrutia (1995). For a debate on how the results vary according to the sample period, see Lo and MacKinlay (1999). 
well as their sources.). ${ }^{24}$ Figure 4 also identifies the booms and crashes obtained using the algorithm described above. The algorithm identifies 146 cycles. The shaded areas denote expansions. The series show well-defined swings with an average duration of about 44 months.

Table 3 examines the characteristics of stock cycles in the 28 countries in the sample and compares them to the behavior of the random walk simulations. This table provides mean values and tests of whether the differences between the actual and simulated samples are statistically significant. Columns 2-3 and 5-6 report the mean amplitude and duration of cycles using the actual and simulated data. Columns 4 and 7 report the significance level of tests of the null hypothesis that mean cycles from the actual and simulated data are equal. The depth of the contraction (height of the expansion) is measured as the change between the peak (trough) and the following trough (peak), as a percent of the mid value of the peak and trough. This measure puts the amplitude of expansions and contractions on an equal foot. Finally, the duration of a contraction (expansion) is defined as the number of periods between a peak (trough) and the following trough (peak).

According to Table 3, booms across all regions oscillate around 74 percent. The typical contraction in stock markets is about 61 percent. The data reveal that contractions tend to be short-lived relative to expansions. The mean duration of contractions is around 18 months, while the mean duration of expansions is around 26 months and statistically different from the duration of contractions at all conventional significance levels. From the table, it is clear that there are significant differences between the amplitude of booms and crashes in the actual data relative to the one that is observed under the null hypothesis of a random walk. The amplitude of booms for the actual data is about 15 percent larger than the average amplitude for the simulated data. Similarly, the average duration of booms for the actual data is about 20 percent longer than the average duration for the simulated data. Analogous comparisons can be made for contraction episodes. Again, contractions obtained from the actual data are significantly more protracted than those obtained from random walk processes.

To provide another picture of the differences between the actual and simulated data, Figure 5 reports the frequency distribution of the amplitude and duration of booms and crashes.

\footnotetext{
${ }^{24}$ As it is common in the international finance and finance literature, we look at stock returns from the point of view of investors with portfolios comprising assets in various countries. This is why, we study returns in one international currency. Alternatively, we could have focused on prices in domestic currency deflated by the
} 
The horizontal axis in each figure shows the size or duration of booms and crashes, the vertical axis shows the frequencies in percent. If stock prices followed a random walk process, the frequency distribution of the amplitude and duration of each phase of the cycle for the actual and the simulated data would be equal. From this figure, it is clear that there are significant differences in the amplitude and duration of booms and crashes relative to what one would expect if stock prices followed random walks. Booms and crashes are more pronounced and protracted than those generated under the null hypothesis of a random walk. KolmogorovSmirnov tests are used to evaluate the null hypothesis of equal frequency distributions of the size and duration of booms and crashes in the actual and random walk data. As shown by the p-value at the bottom of each panel, we reject the null hypothesis that stock prices follow random walk processes.

Figure 6 examines the characteristics of the typical cycle in the four regions. The top panel reports the mean amplitude and duration of booms and crashes in Asia, Europe, the G-7 countries, and Latin America. The bottom panel plots the typical cycle in each region. The horizontal axis in the figure records the number of months before and after the peak of the cycle. The horizontal axis contains 26 months for expansions and 18 months for contractions. These are the durations of the two phases for the typical cycle in our sample. The vertical axis reports the value of the stock index. To obtain the typical cycle, the value of the stock index in each cycle is normalized to 100 at the peak. Each line in this panel represents the average value of the stock index during the 44 months around the peaks of the four regions.

Figure 6 shows that cycles are more pronounced in Latin America. On average, the amplitude of cycles in this region is about twice as large as the amplitude of cycles in the G-7 countries. As expected, the most developed countries, the G-7, have milder stock market cycles, with the Asian and the other European stock market cycles being of intermediate magnitudes. The Asian cycles are larger than the European ones. In contrast to the disparities concerning the amplitude of cycles, the duration of booms and busts is similar across regions, though the ones from developed countries tend to be longer, making the larger amplitudes for emerging markets even more striking. This evidence of more pronounced booms and busts in less developed

domestic price index. Our results do not change substantially when using prices in domestic currency from those discussed in the text. 
economies is consistent with the argument presented in Ventura (2002), according to which bubbles tend to appear in countries with relative low productivity.

\section{Stock market cycles and financial liberalization}

To examine the claim that financial liberalization triggers more protracted and deeper booms and busts in asset markets, we examine the characteristics of financial cycles during episodes of financial repression and liberalization. Our first approach is in the event study tradition, analyzing the behavior of stock markets in the aftermath of liberalization relative to their functioning in repression times, those years before deregulation occurs. To examine the conflicting views that liberalization triggers financial excesses but also contributes to less volatile financial markets, we compare the characteristics of financial cycles in the short run and long run following liberalization. We then report regression results that control for other factors and study the sequencing of the openings. Those results examine whether liberalization creates larger cycles when the first market opens or whether each consecutive opening triggers substantial increases in booms and crashes. The regressions also test whether financial turbulences are just the product of liberalization episodes that start with opening first the capital account, the domestic sector, or the stock market.

\section{A. Event Studies}

Figure 7 examines the characteristics of financial cycles around the time of the overall partial liberalization of financial markets, that is, when at least two sectors are partially liberalized. We classify financial cycles in three categories, those that occur during repression times, those that occur in the short run after liberalization, and those that occur in the long run following liberalization. The short run is defined as the four years after liberalization. The long run includes the fifth year after liberalization and the years thereafter, conditional on the deregulation not being reversed. ${ }^{25}$ The top panel in Figure 7 shows the average amplitude of booms and crashes for all countries in our sample during repression times (the striped bars), the

\footnotetext{
${ }^{25}$ Since the choice of the short-run window is ad-hoc, we also examined the robustness of the results to different definitions of window size. The results for three- and six-year windows are quite similar.
} 
short-run effects of liberalization (the white bars), and the long-run effects of liberalization (the gray bars). It also reports the characteristics of cycles separately for emerging and mature markets since the evidence from these two groups of countries might differ. The bottom panel examines whether the differences of amplitudes across regimes are statistically significant.

The evidence for the 28 countries in the sample indicates that the amplitude of booms substantially increases in the immediate aftermath of liberalization (about 20 percent higher than during repression times). But equity markets stabilize in the long run if liberalization persists, with the amplitude of booms about 25 percent smaller than in repression times. Similarly, the amplitude of crashes increases in the immediate aftermath of liberalization (about 15 percent higher than during repression times), but declines to about 60 percent of its size during repression times if liberalization persists in the long run. As shown in the bottom panel, these differences are statistically significant at conventional levels.

The evidence for the 28 countries, however, obscures important differences across emerging and mature markets. When examined separately, we note that the short-run effects of liberalization in emerging markets are more striking, with booms and crashes in the immediate aftermath of liberalization increasing by about 35 percent over their size during repression. Still, if liberalization persists, financial cycles become less pronounced, with booms about 30 percent smaller than during repression times, and crashes about 90 percent of their size during repression times. On the other hand, the evidence from mature markets indicates that if liberalization triggers more volatile stock markets in the short run, booms and busts do not increase as much as in the case of emerging markets. Moreover, on average, crashes do not increase relative to their value during repression times. Still, liberalization seems to generate more stable financial markets in the long run, with crashes averaging only about 60 percent of their size in repression times.

\section{B. Accounting for domestic and external shocks}

While the evidence in Figure 7 suggests that financial liberalization influences the size of expansions and contractions in financial markets, stock price fluctuations also reflect changes in other market fundamentals. For example, stock prices respond to expansions and recessions in 
the domestic economy. They also react to world economic conditions. ${ }^{26}$ The omission of these variables may bias our results, especially since the timing of liberalization may not be fortuitous. In fact, we have described in Section I that Latin American countries reintroduce controls on domestic interest rates and credit and re-impose controls on capital flows following the hikes in interest rates in industrial countries in the early 1980s. Also, many emerging markets liberalize their financial markets when international capital flows resume in the late 1980s. Insofar as countries react to "bad times" by adopting capital controls and to "good times" by relaxing them, there is the danger that we may ascribe the increase in the size of booms to liberalization and the amplification of crashes to capital controls, when in fact it is the world market condition the one fueling changes in stock prices.

To account for these factors, the event study analysis is complemented with regressions that control for domestic and world economic conditions. In particular, we examine the role of growth in domestic and world economic activity and changes in world real interest rates. We estimate the following equation by least squares with heteroskedastic-consistent standard errors,

$$
\text { amplitude }_{i}=\boldsymbol{\alpha}^{\prime} \mathbf{X}_{i}+\rho_{1} d_{i}^{r}+\beta_{1} d_{i}^{s r}+\lambda_{1} d_{i}^{l r}+\varepsilon_{i},
$$

where amplitude $_{i}$ is the amplitude of expansion (contraction) $i . \quad \mathbf{X}_{i}$ is a matrix of control variables that includes the change in world real interest rate, the world output growth, and the domestic output growth during each expansion (contraction). $d_{i}^{r}$ is a dummy variable equal to one if the cycle occurs during "repression" times, and zero otherwise. $d_{i}^{s r}$ is a "short-run" dummy variable equal to one if the cycle occurs in the immediate aftermath of financial liberalization (four-year window), and zero otherwise. $d_{i}^{l r}$ is a "long-run" dummy variable equal to one if the cycle occurs after four years have elapsed from the time of financial liberalization, and zero otherwise. The world real interest rate is proxied with the U.S. federal funds real interest rate, world output is the average of the industrial production indexes of the G3 countries, and domestic output is captured by the index of industrial production in the domestic economy. All data come from the IMF's International Financial Statistics.

The results from this estimation are shown in Table 4. As in Figure 7, this table examines the effects of overall partial financial liberalization (when at least two sectors have

\footnotetext{
${ }^{26}$ For example, Calvo, Leiderman, and Reinhart (1993) argue that decreases in U.S. interest rates trigger large capital flows to emerging markets, which in turn fuel increases in asset prices.
} 
been partially liberalized). As expected, fluctuations in the world interest rate affect stock market cycles as does output growth, with a one percentage point increase in the world real interest rate leading to a five percentage point contraction in the amplitude of stock market expansions. Similarly, booms and crashes in stock markets are also explained by upturns and recessions in the domestic economy. Even after accounting for these other determinants of fluctuations in stock prices, financial liberalization still matters. Financial liberalization triggers larger cycles in the short run and stabilizes financial markets in the long run. Interestingly, once we control for the state of the economy (domestic and foreign) and for interest rate fluctuations, the short-run effects of financial liberalization become even more pronounced. For example, in the immediate aftermath of liberalization, booms increase by about 40 percent in emerging markets and by 55 percent in mature markets relative to repression times. Similarly, crashes in emerging markets increase by 30 percent in the immediate aftermath of liberalization vis-à-vis repression times.

Note that the results in Figure 7 and Table 4 suggest two tales about the aftermath of liberalization reforms. While larger booms follow liberalization in both emerging and mature markets, it is only in emerging markets that crashes are more severe following liberalization. The average short-run experience in emerging markets seems to support the evidence from the crisis literature that concludes that liberalization leads to excessive financial booms and crashes. Liberalization episodes do not seem to bring (on average) this short-run pain to mature markets; larger booms are not followed by larger crashes, suggesting that larger booms may just reflect the reduction in the cost of capital once deregulation takes place, as the finance literature

argues. $^{27}$ Still, financial liberalization brings more stable financial markets in both emerging and mature market economies in the long run. In Section V, we examine possible explanations for the varied short-run effects of liberalization as well as for the long-run gains across countries.

\section{Sequencing of Liberalization}

So far we have studied the liberalization across all markets. Now we turn to examine whether the short-run increase in boom-bust amplitudes occurs every time a new sector is

\footnotetext{
${ }^{27}$ As always averages may hide exceptions, Denmark, Finland, Norway, and Sweden suffer financial collapses and banking crises in the early 1990 s following liberalization.
} 
deregulated and whether the sequencing of the openings matters. Table 5 examines whether the short-run increase in booms and busts occurs every time a new sector is deregulated. We limit our search to the deregulation of the first two sectors. We define repression times as those episodes in which all sectors are closed. The short-run liberalization periods are the four years after the opening of the first sector and the four years after the opening of the second sector. The long-run liberalization episode includes the fifth year after the opening of the second sector and the following years if the liberalization reform is not reversed.

We estimate the following regression,

$$
\text { amplitude }_{i}=\boldsymbol{\alpha}^{\prime} \mathbf{X}_{i}+\rho_{1} d_{i}^{r}+\beta_{1} d_{i}^{s r, 1,2}+\beta_{2} d_{i}^{s r, 2}+\lambda_{1} d_{i}^{l r, 2}+\varepsilon_{i} .
$$

The new variable $d_{i}^{s r, 1,2}$ is a dummy variable equal to one if the cycle occurs in the immediate aftermath of financial liberalization (four-year window after the first sector is deregulated and four-year window after the second sector is deregulated), and zero otherwise. $d_{i}^{s r, 2}$ is a dummy variable equal to one if the cycle occurs in the four years after the deregulation of the second sector, and zero otherwise. $d_{i}^{l r, 2}$ is a dummy variable equal to one if the cycle occurs after four years have elapsed from the time of the liberalization of the second sector, and zero otherwise. Thus, the average amplitude of booms (crashes) in the aftermath of the first opening is captured by $\beta_{1}$, while that of the second market opening is captured by $\beta_{1}+\beta_{2}$.

While the evidence on short- and long-run effects of financial liberalization is not reversed, the focus on the first and second openings reveals some important differences. Interestingly, the increase in the amplitude of booms is similar following the first and second opening, but crashes in the immediate aftermath of the first opening are smaller than those observed during repression times. The amplitude of crashes in emerging markets only increases following the opening of the second sector. Again, this evidence is consistent with the results from the crisis literature, which finds that booms of credit persist for several years following the deregulation of financial markets with these booms in turn fueling protracted bull markets.

Table 6 examines the effects on financial markets of various types of sequencing of the deregulation process. We estimate the following regression,

$$
\text { amplitude }_{i}=\boldsymbol{\alpha}^{\prime} \mathbf{X}_{i}+\rho_{1} d_{i}^{r}+\beta_{1} d_{i}^{s r, 1,2}+\beta_{2} d_{i}^{s r, 2}+\beta_{3} d_{i}^{C A}+\beta_{4} d_{i}^{S M}+\lambda_{1} d_{i}^{l r, 2}+\varepsilon_{i} .
$$

The variables $d_{i}^{C A}$ and $d_{i}^{S M}$ help to capture the possible differential effect on booms and crashes of opening respectively the capital account and the stock market first. These dummy variables 
are equal to one if the cycle occurs during the four years after that particular sector is liberalized, and zero otherwise. The average amplitude of booms (crashes) in the aftermath of the first opening, when the liberalization reform is initiated with the deregulation of the domestic financial sector, is captured by $\beta_{1}$. If the liberalization reform starts with the opening of the capital account (stock market), the amplitude of booms or crashes in the four years after the first opening is captured by $\beta_{1}+\beta_{3}\left(\beta_{1}+\beta_{4}\right)$.

Our results indicate that the ordering of liberalization does not matter in general. Opening the capital account or the stock market first does not have a different effect than opening the domestic financial sector first. But one exception exists; crashes seem to be larger in emerging markets if the capital account opens up first. This might provide some mild support to the usual claim that the capital account should be opened last.

In sum, our results suggest that we gain from examining the effects of deregulation of different sectors. In particular, we find that crashes become more pronounced not at the onset of the liberalization reform but after some years have elapsed. Interestingly, the sequencing of financial liberalization does not seem to matter when evaluating the effects on financial cycles. Finally, as also shown in the previous section, the experiences of mature and emerging markets look different in the aftermath of financial liberalization. We analyze these differences next.

\section{Financial liberalization and institutional reform}

Our findings necessarily provoke several questions. What is the essential ingredient for more stable financial markets in the long run? Is it just financial liberalization? Or, does liberalization trigger some other changes that in turn deliver more stable financial markets in the long run? Can we explain the differences in the aftermath of financial liberalization in mature and emerging markets? And, is it possible to avoid the short-run pain following liberalization?

These questions have generated an intense debate on the sequencing of liberalization and institutional reform. ${ }^{28} 29$ Many have argued that it is very risky to open up financial systems.

\footnotetext{
${ }^{28}$ There is a related literature that studies the link between capital controls and institutions. See, for example, Alesina, Grilli, and Milesi-Ferretti (1993).

${ }^{29}$ Note that the sequencing mentioned here discusses the optimal order between financial liberalization and other financial sector reforms. While the sequencing mentioned in the previous section deals with the order of liberalization of the stock market, the domestic financial sector, and the capital account.
} 
During financial repression, banks tend to have poor balance sheets. ${ }^{30}$ Protected from outside competition, badly regulated, and badly supervised banks do not have the pressure to run efficiently. Liberalization in this scenario unveils a new problem, as protected domestic banks suddenly get access to new sources of funding, triggering protracted financial booms. Moreover, financial liberalization brings competition and lowers bank profits, eroding banks' franchise values and lowering their incentive for making good loans. Naturally, this worsens problems of moral hazard. ${ }^{31}$ Based on these views, a standard recommendation on sequencing is to first clean up domestic financial institutions and change government institutions, then deregulate the industry and open up the capital account.

This discussion about sequencing may be irrelevant if the timing is such that reforms never predate liberalization, with institutional changes happening mostly as a result of financial deregulation. To shed new light on this sequencing debate, we collect data on the quality of institutions as well as data on the laws governing the proper functioning of financial systems. Then, we compare the timing of financial liberalization and institutional reforms. The data on the quality of institutions is captured by the index of law and order. ${ }^{32}$ To better assess the functioning of the financial system, we use information on the existence and enforcement of insider trading laws, constructed by Bhattacharya and Daouk (2002). Appendix Table 3 reports the time of improvement in the law and order index, the time when the insider trading law is passed, and the time when insider trading starts to be prosecuted. We characterize as an improvement in the quality of government institutions when the index of law and order increases by one unit and this change is maintained for at least two years.

The top panel in Table 7 examines the sequencing of liberalization and reform in our sample of 28 countries. It shows the probabilities that financial liberalization occurs conditional on reforms having already been implemented. In particular, we look at whether reforms to institutions occur prior to the partial or full liberalization of the financial sector. If governments clean up financial institutions and improve the quality of institutions prior to deregulating the financial sector, one would expect this probability to be close to one.

\footnotetext{
${ }^{30}$ This is shown, for example, in Rojas-Suarez and Weisbrod (1994).

${ }^{31}$ See Akerlof and Romer (1993) and Hellman, Murdok, and Stiglitz (2000).

${ }^{32}$ This index is published in the International Country Risk Guide (ICRG). The law sub-index assesses the strength and impartiality of the legal system, while the order sub-index assesses the popular observance of the law. Each index can take values from one to three, with lower scores for less tradition for law and order.
} 
The evidence for emerging and mature markets displayed in Table 7 suggests that reforms to institutions occur mostly after liberalization is implemented. For example, in the case of emerging markets, in only 18 percent of the cases, law and order improves prior to the partial liberalization of financial markets. Also, while in 62 percent of the cases, the laws prosecuting insider trading exist prior to partial financial liberalization, insider trading starts to be prosecuted in only 11 percent of the cases before the partial deregulation of the financial sector. Interestingly, law and order improves substantially following partial liberalization. By the time the financial sector becomes fully liberalized, the quality of institutions, as measured by the law and order index, has improved in 64 percent of the cases. Also, insider trading prosecution is enforced in 44 percent of the cases before the full liberalization of the financial sector.

This evidence casts doubts on the notion that governments tend to implement institutional reforms before they start deregulating the financial sector. On the contrary, the evidence suggests that partial liberalization fuels institutional reforms. The evidence for mature markets is less compelling. Still, insider trading prosecution is only enforced in 17 percent of the cases prior to the partial liberalization of the financial sector, but in this case, in 44 percent of the cases, institutions improve prior to the full liberalization of the financial sector. Again, both indicators show that reforms continue following partial liberalization.

There are several reasons that can explain why financial liberalization might prompt institutional reforms. First, as discussed in Rajan and Zingales (2001), well-established firms may oppose reforms that promote financial development because it breeds competition. These firms can even be hurt by financial development as financial development implies better disclosure rules and enforcement (reducing the importance of these firms' collateral and reputation) and permits newcomers to enter and compete away profits. We can add that incumbents may oppose the removal of capital controls as capital can flow away to more attractive destinations, limiting their sources of funds. However, opposition may be weaker in the presence of worldwide abundance of trade and cross-border flows. In these times, free access to international capital markets will allow the largest and best-known domestic firms to tap foreign markets for funds, with the support for financial liberalization becoming stronger. But financial liberalization sows the seeds of destruction of the old protected and inefficient financial sector, as foreign and domestic investors (now with access to international capital markets) require better enforcement rules. 
Second, as mentioned before, the liberalization and the gradual integration of emerging markets with international financial markets by itself may help to fortify the domestic financial sector. Foreign investors have overall better skills and information and can thus monitor management in ways local investors cannot. Liberalization, moreover, allows firms to access mature capital markets. Firms listing on foreign stock markets are also in the jurisdiction of a superior legal system and have higher disclosure standards.

Third, the integration with world markets and institutions tends to speed up the reform process to achieve a resilient financial system. Capital markets can help supervise domestic financial institutions, imposing stricter market discipline, increasing transparency and the diffusion of information, and even pushing governments into guaranteeing that its financial system is well supervised and regulated. ${ }^{33}$

To have a sense of the effects of changes in institutions on financial booms and busts, we estimate the following regression,

$$
\text { amplitude }_{i}=\boldsymbol{\alpha}^{\prime} \mathbf{X}_{i}+\rho_{1} d_{i}^{r}+\beta_{1} d_{i}^{s r}+\lambda_{1} d_{i}^{l r}+\tau_{1} d_{i}^{L \& O}+\tau_{2} d_{i}^{I T A}+\tau_{2} d_{i}^{I T E}+\varepsilon_{i} .
$$

This regression is the same as regression (1) but also evaluates the possible effects of changes in government institutions. $\quad d_{i}^{L \& O}$ is a dummy variable equal to one if the boom (crash) occurs when the law and order index has improved or it is at its highest level, and zero otherwise. $d_{i}^{I T A}$ is a dummy variable equal to one if the boom (crash) occurs following the approval of the law prosecuting insider trading, and zero otherwise. $d_{i}^{I T E}$ is a dummy variable equal to one if the boom (crash) occurs when insider trading prosecution is enforced and zero otherwise.

The results are also reported in Table 7. Note that improvements in the law and order index trigger more stable financial markets, with the amplitude of booms and crashes declining about 18 and 9 percentage points, respectively. This evidence provides one possible explanation of why mature markets, with better government institutions, do not experience the larger crashes observed in emerging markets in the aftermath of liberalization. ${ }^{34}$

\footnotetext{
${ }^{33}$ See Gourinchas and Jeanne (2002) for a model on the link between financial liberalization and social infrastructure.

${ }^{34}$ For more discussion on this issue, see Martin and Rey (2002).
} 


\section{Conclusions}

This paper presented a new approach to understand the effects of financial liberalization by introducing a novel database on liberalization and by focusing on booms and busts in stock market prices. Our main results can be summarized as follows.

First, our chronology of financial liberalization indicates that domestic and international financial liberalization is a process in which different types of restrictions are removed over time. Moreover, while liberalization has been an uninterrupted process in most mature markets, it has been characterized by reversals in emerging markets, in which capital controls and restrictions are at times reintroduced. We also found that the pattern of liberalization varies across regions, with developed countries liberalizing first their stock markets and developing economies opening first their domestic financial sector.

Second, with regard to the possible changing nature of financial cycles, our analysis showed that stock market booms and busts have not intensified in the long run after financial liberalization. In fact, despite the claim that financial integration leads to volatile capital markets around the world, stock market cycles become less pronounced after liberalization. Still, in the short run, we found that financial liberalization does tend to trigger larger cycles. Interestingly, the short-run effects of liberalization vary across mature and emerging markets. The evidence from emerging markets, with larger booms and crashes in the immediate aftermath of liberalization, provides some support to the arguments of excessive financial cycles following liberalization. In contrast, the evidence from mature markets, with larger bull markets but less pronounced bear markets in the aftermath of deregulation, supports the view that liberalization is beneficial even in the short run.

Third, to explain the contrasting short- and long-run effects of financial liberalization, we explored the dynamics of liberalization and institutional reform. We collected information on the quality of institutions as well as data on the laws governing the functioning of the financial system. The evidence suggests that institutional reforms do not predate liberalization. Most of the times, government reforms are implemented within a few years after the partial opening of financial markets. As the quality of institutions improves, financial cycles become less pronounced. Perhaps due to lack of correct incentives, countries do not tend to improve their financial systems before liberalization, disregarding the typical policy prescriptions. 
To conclude, this paper opened several avenues for future research. First, the new dataset will allow researchers to understand better the link between financial liberalization and financial development, investment, and growth. Second, the richness of the data will allow researchers to better comprehend the channels through which financial deregulation impacts economies. Third, more research on whether financial liberalization can be a first step to institutional reforms would be welcome. Last but not least, the relation between financial liberalization and reforms leaves unanswered the question of whether countries can deregulate financial systems without becoming vulnerable to crises. 


\section{References}

Akerlof, G. and P. Romer. 1993. "Looting: The Economics Underworld of Bankruptcy for Profit.” Brookings Papers on Economic Activity, September, pp. 1-60.

Alesina, A., V. Grilli, and G. Milesi-Ferretti. 1993. "The Political Economy of Capital Controls," in L. Leiderman and A. Razin, eds., Capital Mobility: New Perspectives, Cambridge University Press.

Allen, F. and G. Gorton. 1993. "Churning Bubbles.” Review of Economic Studies Vol. 60(4), pp. 813-836.

Allen, F., S. Morris, and A. Postlewaite. 1993. "Finite Bubbles with Short Sale Constraints and Asymmetric Information.” Journal of Economic Theory Vol. 61(2), pp. 206-229.

Baxter, M. and R. King. 1995. "Measuring Business Cycles: Approximate Band-Pass Filters for Economic Time Series." Review of Economics and Statistics Vol. 81(4), pp. 575-93.

Bekaert, G., and C. Harvey. 2000. "Foreign Speculators and Emerging Equity Markets." Journal of Finance Vol. 55(2), pp. 565-613.

Bekaert, G., C. Harvey, and C. Lundblad. 2001. "Does Financial Liberalization Spur Growth?” NBER Working Paper No. 8245.

Bhattacharya, U. and H. Daouk. 2002. "The World Price of Insider Trading." Journal of Finance Vol. 57(1), pp. 75-108.

Bry, G. and C. Boschan. 1971. Cyclical Analysis of Time Series: Selected Procedures and Computer Programs. New York: Columbia University Press for the NBER.

Burns, A. and W. Mitchell. 1946. Measuring Business Cycles. NBER Studies in Business Cycles No.2, New York: National Bureau of Economic Research.

Calvo, G., L. Leiderman, and C. Reinhart. 1993. "Capital Inflows and Real Exchange Rate Appreciation in Latin America: The Role of External Factors." IMF Staff Papers No. 40, pp. 108-51.

Calvo, G. and E. Mendoza. 2000. "Rational Contagion and the Globalization of Securities Markets." Journal of International Economics Vol. 51(1), pp. 79-113.

Cecchetti, S., P. Lam, and N. Mark. 1990. "Mean Reversion in Equilibrium Asset Prices." American Economic Review Vol. 80(3), pp. 398-418.

Corsetti, G., N. Roubini, and P. Pesenti. 1999. "What Caused the Asian Currency and Financial Crisis?" Japan and the World Economy Vol. 11(3), pp. 305-73.

De Long, J. B., A. Shleifer, L. H. Summers, and R. J. Waldmann. 1990. "Noise Trader Risk in Financial Market.” Journal of Political Economy Vol. 98(4), pp. 703-738.

Demirguc-Kunt, A. and E. Detragiache. 1999. "Financial Liberalization and Financial Fragility." In Annual World Bank Conference on Development Economics, World Bank, DC, pp. 303-31.

Edison, H. and F. Warnock. 2002. "A Simple Measure of the Intensity of Capital Controls." Forthcoming, Journal of Empirical Finance.

Eichengreen, B. and C. Wyplosz. 1993. "The Unstable EMS.” Brookings Papers on Economic Activity No. 1, pp. 51-144.

Fama, E. and K. French. 1988. "Permanent and Temporary Components of Stock Prices." Journal of Political Economy Vol. 96, pp. 246-273.

Frankel, J.. 2000. “Globalization of the Economy.” NBER Working Paper No. 7858.

Frennberg, P. and B. Hansson. 1993. "Testing the Random Walk Hypothesis on Swedish Stock Prices: 1919-1990.” Journal of Banking and Finance Vol. 17, pp. 175-191. 
Gourinchas, P. and O. Jeanne. 2002. "On the Benefits of Capital Account Liberalization for Emerging Economies." Mimeo, Princeton University.

Grinblatt, M., S. Titman, and R. Wermers. 1995. "Momentum Investment Strategies, Portfolio Performance, and Herding: A Study of Mutual Fund Behavior." American Economic Review Vol. 85(5), pp. 1088-1105.

Hellman, T., K. Murdock, and J. Stiglitz. 2000. "Liberalization, Moral Hazard in Banking, and Prudential Regulation: Are Capital Requirements Enough?” American Economic Review Vol. 90(1), pp. 147-165.

Henry, P. 2000. "Stock Market Liberalization, Economic Reform, and Emerging Market Equity Prices." Journal of Finance Vol. 55(2), pp. 529-563.

Hodrick, R. and E. Prescott. 1997. "Post-War U.S. Business Cycles: An Empirical Investigation." Journal of Money, Credit, and Banking Vol. 29(1), pp. 1-16.

Jayaratne, J. and P. Strahan. 1996. "The Finance-Growth Nexus: Evidence from Bank Branch Deregulation.” Quarterly Journal of Economics Vol. 111(3), pp. 639-670.

Kaminsky, G. and C. Reinhart. 1999. "The Twin Crises: The Causes of Banking and Balance-ofPayments Problems." American Economic Review Vol. 89(3), pp. 473-500.

Karolyi, A. and R. Stulz. 2002. "Issues in International Asset Pricing." Forthcoming, Handbook of the Economics of Finance, G. Constantinides, M. Harris, and R. Stulz, eds., NorthHolland .

King, R. and R. Levine. 1993. "Finance and Growth: Schumpeter Might Be Right." Quarterly Journal of Economics Vol. 108(3), pp. 717-737.

Krugman, P. 1998. "Saving Asia: It's Time to Get Radical.” Fortune, September 7, pp. 74-80.

Levine, R. 2001. "International Financial Liberalization and Economic Growth." Review of International Economics Vol. 9(4), pp. 684-98.

Lo, A. and C. MacKinlay. 1988. "Stock Market Prices Do Not Follow Random Walks: Evidence From a Simple Specification Test." Review of Financial Studies Vol. 1, pp. 41-66.

Lo, A. and C. MacKinlay. 1999. A Non-Random Walk Down Wall Street. Princeton, N.J.: Princeton University Press.

McKinnon, R. and H. Pill. 1997. "Credible Economic Liberalizations and Overborrowing." American Economic Review Vol. 87(2), pp. 189-93.

Martin, P. and H. Rey. 2002. "Financial Globalization and Emerging Markets: With or Without Crash.” Mimeo, Princeton University.

Mishkin, F. 2001. "Financial Policies and the Prevention of Financial Crises in Emerging Market Countries." NBER Working Paper No. 8087.

Mitchell, W. 1927. Business Cycles: The Problem and its Setting. New York: National Bureau of Economic Research.

Mitchell, W. and A. Burns. 1938. Statistical Indicators of Cyclical Revivals. NBER Bulletin Vol. 69, New York, reprinted as Chapter 6 of G. H. Moore, ed., Business Cycle Indicators, 1961, Princeton University Press, Princeton, NJ.

Obstfeld, M. 1998. "The Global Capital Market: Benefactor or Menace?” Journal of Economic Perspectives Vol. 12(4), pp. 9-30.

Obstfeld, M. and K. Rogoff. 2001. "Perspectives on OECD Economic Integration: Implications for U.S. Current Account Adjustment." In Global Economic Integration: Opportunities and Challenges. Federal Reserve Bank of Kansas City. 
Obstfeld, M. and A. Taylor. 2002. "Global Capital Markets." Bordo, M., Taylor A., and Williamson, J., eds., Globalization in Historical Perspective. Forthcoming, University of Chicago Press.

Poterba, J. M. and L. H. Summers. 1988. "Mean-Reversion in Stock Prices: Evidence and Implications." Journal of Financial Economics Vol. 22, pp. 7-59.

Quinn, D. and C. Inclan. 1997. "The Origins of Financial Openness: A Study of Current and Capital Account Liberalization." American Journal of Political Science Vol. 41(3), pp. 771-813.

Rajan, R. G. and L. Zingales. 1998. "Financial Dependence and Growth." American Economic Review Vol. 88(3), pp. 559-86.

Rajan, R. G. and L. Zingales. 2001. "The Great Reversals: The Politics of Financial Development in the $20^{\text {th }}$ Century." Forthcoming, Journal of Financial Economics.

Rodrik, D. 1998. "Who Needs Capital Account Convertibility?" In S. Fischer and others, eds., Should the IMF Pursue Capital-Account Convertibility?, Essays in International Finance No. 207, Department of Economics, Princeton University, May.

Rodrik, D. 2000. "Governing the Global Economy: Does One Architectural Style Fit All?" Brookings Trade Forum 1999, Brookings Institution.

Rojas-Suarez, L. and S. Weisbrod. 1994. "Financial Market Fragilities in Latin America: from Banking Crisis Resolution to Current Policy Challenges." IMF Working Paper 94/117.

Schneider, M. and A. Tornell. 2001. "Boom-Bust Cycles and the Balance Sheet Effect." Mimeo, UCLA.

Soros, G. 2002. On Globalization. Public Affairs.

Stiglitz, J. 1999. "Bleak Growth for the Developing World." International Herald Tribune, April 10-11, pp. 6.

Stiglitz, J. 2002. Globalization and Its Discontents. W.W. Norton \& Company.

Stock, J. and M. Watson. 1998. "Business Cycle Fluctuations in U.S. Macroeconomic Time Series." NBER Working Paper No. 6528.

Stulz, R. 1999. "Globalization of Capital Markets and the Cost of Capital." Journal of Applied Corporate Finance Vol. 12(3), pp. 8-25.

Tornell, A. and F. Westermann. 2002. "Boom-Bust Cycles in Middle Income Countries: Facts and Explanations.” NBER Working Paper No. 9219.

Urrutia, J. 1995. "Tests of Random Walk and Market Efficiency for Latin American Emerging Equity Markets." Journal of Financial Research, Vol. 18 (3), pp. 299-309.

Williamson, J. and M. Mahar. 1998. "A Survey of Financial Liberalization." Essays in International Finance No. 211. Department of Economics, Princeton University.

Ventura, J. 2002. "Bubbles and Capital Flows." Mimeo, MIT.

Wyplosz, C., "How Risky is Financial Liberalization in Developing Countries?" Mimeo. September 2001 
Table 1

Liberalization Dates

\begin{tabular}{|c|c|c|c|c|c|}
\hline Country & Capital Account & Domestic Financial Sector & Stock Market & Partial Liberalization & $\begin{array}{l}\text { Full Liberalization } \\
\end{array}$ \\
\hline \multicolumn{6}{|l|}{$\overline{\text { Asia }}$} \\
\hline Hong Kong & Jan $73-$ & Aug 94p/May 00 - & Pre 73 - & Jan 73 - & Aug 94 - \\
\hline Indonesia & Jan 78p/Jan 88 - Feb 91 & Jan 78p/Jan 83 - & Dec 88p/Aug 89- & Jan 83 - & Dec 88 - Feb 91 \\
\hline Korea & Jan 93p/Jan $96-$ & Jan 88p/Jan 95 - & Jan 91p/May 98 - & Jan 93 - & Jan 96 - \\
\hline Malaysia & $\begin{array}{r}\text { Jun } 79 \text { p - Dec } 93 \\
\text { Sep } 94 \text { - Aug } 98\end{array}$ & $\begin{array}{c}\text { Oct } 78 p-\text { Sep } 85 \\
\text { Feb } 91 \text { - }\end{array}$ & July 73/Jan 75p/84 - Dec 97 & Jun 79 - Aug 98 & $\begin{array}{l}\text { Feb } 91 \text { - Dec } 93 \\
\text { Sep } 94 \text { - Dec } 97\end{array}$ \\
\hline Philippines & $\begin{array}{c}\text { Jan } 76 p-\text { Dec } 82 \\
\text { Jan } 94 p-\end{array}$ & Jul 81p/Dec 82 - & Mar 86p/Jan 94 - & Mar 86 - & Jan 94 - \\
\hline Taiwan & Jan 87p/Jan 97 - & Sep 84p/Jul 89 - & Jan 87p/Apr 98 - & Jan 87 - & Jan 97 - \\
\hline Thailand & $\begin{array}{c}\text { Jan } 79 p-\text { Dec } 81 \\
\text { Jan 92/Aug } 95 p-\text { Apr } 97 \\
\text { Jan } 98-\end{array}$ & Jun 89 p/Jun 92 - & Jan $88 \mathrm{p} /$ Jan 90 - & Jan 90 - & $\begin{array}{c}\text { Jan } 92-\text { Apr } 97 \\
\text { Jan } 98-\end{array}$ \\
\hline \multicolumn{6}{|l|}{ Europe } \\
\hline Denmark & Oct 88 - & 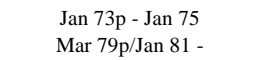 & Pre 73 - & $\begin{array}{c}\text { Jan } 73-\text { Dec } 75 \\
\text { Mar } 79-\end{array}$ & Oct 88 - \\
\hline Finland & Jan 87 p/Jun 89 - & Jan $86 \mathrm{p} /$ Jan 90 - & Pre 73 p/Jan 90 - & Jan $87-$ & Jan 90 - \\
\hline $\begin{array}{l}\text { Ireland } \\
\text { Norway }\end{array}$ & Jan $79 \mathrm{p} / \mathrm{Jan} 92-$ & May $85 \mathrm{p} / \mathrm{Feb} 86-$ & Pre 73p/Jan 92 - & May 85 - & Jan $92-$ \\
\hline Norway & $\begin{array}{l}\text { Jan } 80 \mathrm{p}-\text { Dec } 81 \\
\text { Jan } 85 \mathrm{p} / \mathrm{Jan} 88-\end{array}$ & $\begin{array}{l}\text { Jan } 79 \text { - Dec } 79 \\
\text { Sep } 85 \text { p/Jan } 88 \text { - }\end{array}$ & Jan 84 p/Jan $89-$ & Sep 85 - & \\
\hline Portugal & Sep 89p /Aug 92 - & Jan 84p/Mar 90 - & $\begin{array}{l}\text { Pre } 73 \text { - Dec } 75 \\
\text { Jan } 86-\end{array}$ & Jan 86 - & Mar 90 - \\
\hline Spain & Jan 75p/Jan 80/Jun 88p/Dec 92 - & Jan $74 \mathrm{p} / \mathrm{Jan} 81$ - & Pre 73 - & Jan 74 - & Jan 80 - \\
\hline Sweden & Jan $84 \mathrm{p} / \operatorname{Jan} 89-$ & Jan $78 \mathrm{p} / \mathrm{Jan} 85-$ & Pre $73 p /$ Jan 80 - & Jan 80 - & Jan $85-$ \\
\hline \multicolumn{6}{|l|}{ G-7 } \\
\hline Canada & Pre 73p/Mar 75 - & Pre 73 - & Pre 73 - & Jan 73 - & Jan 73 - \\
\hline France & Jun $85 \mathrm{p} / \mathrm{Jan} 90$ - & Jan 85 - & Pre 73 - & Jan $85-$ & Jun 85 - \\
\hline Germany & Pre 73p/Mar 81 - & Pre 73 - & Pre 73 - & Jan 73 - & Jan 73 - \\
\hline Italy & May 87p/Jan 92 - & $\begin{array}{c}\text { Jan } 74-\text { Dec } 74 \\
\text { Jan } 81-\end{array}$ & Pre 73 - & $\begin{array}{c}\text { Jan } 74-\text { Dec } 74 \\
\text { Jan } 81-\end{array}$ & May 87 - \\
\hline Japan & Jan 79p/Jul 80 - & Jan 79p/Dec 91 - & Jan 85 - & Jul 80 - & Jan 85 - \\
\hline United Kingdom & Oct $73 p /$ Oct 79 - & Jan $81-$ & Pre 73 - & Oct 73 - & Jan 81 - \\
\hline United States & Jul 73 - & Pre 73p/Jan 82 - & Pre 73 - & Jan 73 - & Jul 73 - \\
\hline \multicolumn{6}{|l|}{ Latin America } \\
\hline Argentina & $\begin{array}{c}\text { Apr 76p/Dec } 78 \text { - Mar } 82 \\
\text { Dec } 89 \text { - }\end{array}$ & $\begin{array}{c}\text { Jan } 77-\text { Jun } 82 \\
\text { Oct } 87-\end{array}$ & $\begin{array}{c}\text { Jan } 77 p-\text { Mar } 82 \\
\text { Jan } 89-\end{array}$ & $\begin{array}{c}\text { Jan } 77-\text { Mar } 82 \\
\text { Jan } 89-\end{array}$ & $\begin{array}{c}\text { Dec } 78 \text { - Mar } 82 \\
\text { Dec } 89-\end{array}$ \\
\hline Brazil & $\begin{array}{c}\text { Jan } 90 p-\text { Dec } 93 \\
\text { Mar 95p - }\end{array}$ & $\begin{array}{l}\text { Jan } 76-\text { Dec } 78 \\
\text { Jan } 88 \text { p/Jan } 89-\end{array}$ & Pre 73 p/Jun 91 - & $\begin{array}{c}\text { Jan } 76-\text { Jan } 79 \\
\text { Jan } 89-\end{array}$ & $\begin{array}{c}\text { Jun } 91-\text { Dec } 93 \\
\text { Mar } 95-\end{array}$ \\
\hline Chile & $\begin{array}{c}\text { Jun } 79 \text { p - Dec } 82 \\
\text { Apr } 90 / \text { Jun } 91 \text { p/Sep } 98-\end{array}$ & $\begin{array}{c}\text { Jan } 74 \text { p/May } 75 \text { - Nov } 82 \\
\text { Jan } 84 \text { p/Jan } 85 \text { - }\end{array}$ & Jan 87 p/Jan 92 - & $\begin{array}{c}\text { Jun } 79-\text { Nov } 82 \\
\text { Jan } 87-\end{array}$ & $\begin{array}{c}\text { Apr } 90 \text { - May } 91 \\
\text { Jan } 92-\end{array}$ \\
\hline Colombia & Jan $91 \mathrm{p} /$ Sep $98-$ & $\begin{array}{c}\text { Aug 74p/Sep } 1980 \text { - Dec } 85 \\
\text { Jul } 86 \text { - }\end{array}$ & Jan 91p - & Jan 91 - & Sep 98 - \\
\hline Mexico & $\begin{array}{c}\text { Pre } 73 \text { - Jul } 82 \\
\quad \text { Nov } 91 \text { - }\end{array}$ & 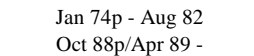 & Jan 89p/Jan 91 - & $\begin{array}{c}\text { Jan } 74-\text { Jul } 82 \\
\text { Apr } 89-\end{array}$ & Nov 91 - \\
\hline Peru & Pre 73p - Dec 86 & Pre $73 p-$ Dec 81 & Jan 92 - & Jan 91 - & Jan 92 - \\
\hline Venezuela & $\begin{array}{c}\text { Jan } 91- \\
\text { Pre } 73 \text { - Jan } 83 \\
\text { Mar } 89-\text { Dec } 93 \\
\text { Apr } 96-\end{array}$ & $\begin{array}{c}\text { Jan } 91- \\
\text { Aug } 81-\text { Jan } 84 \\
\text { Jan } 89-\text { Aug } 94 \\
\text { Apr } 96-\end{array}$ & $\begin{array}{c}\text { Jan } 77 \text { - Dec } 87 \\
\text { Jan } 90 \text { - Jun } 93 \\
\text { Jun } 95 \text { - }\end{array}$ & $\begin{array}{c}\text { Jan } 77 \text { - Jan } 84 \\
\text { Mar } 89 \text { - Dec } 93 \\
\text { Apr } 96-\end{array}$ & $\begin{array}{c}\text { Aug } 81-\text { Jan } 83 \\
\text { Jan } 90-\text { Jun } 93 \\
\text { Apr } 96-\end{array}$ \\
\hline
\end{tabular}

This table reports the dates of partial and full liberalization of financial markets. The first three columns provide information by sector: capital account, domestic financial sector, and the stock market. The last two columns provide information on an integral measure of financial liberalization. The dates are based on the criteria displayed in Appendix Table 1. A country is considered to be fully liberalized when at least two sectors are fully liberalized and the third one is partially liberalized. A country is considered to be partially liberalized if at least two sectors are partially liberalized. Otherwise, the country is considered to be financially repressed. If there is no information about the month of liberalization, we use January (December) if the corresponding report indicates that liberalization is implemented at the beginning (end) of the year. "-" followed by a blank means that it covers the period until June 1999. Pre 73 (Pre 73p) means that the sector is already fully (partially) liberalized at that time, with no significant measures taken at that date. 

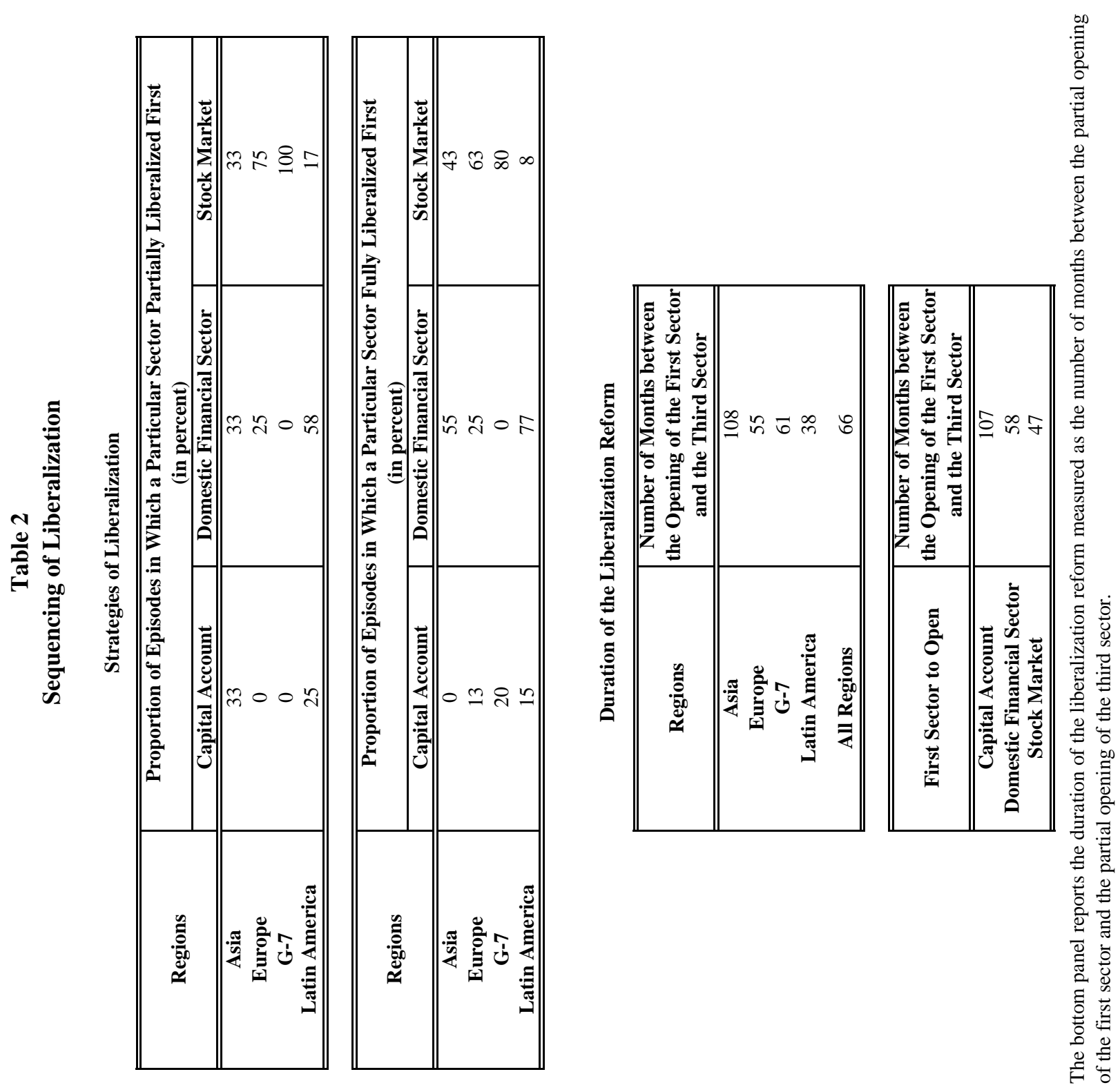
Table 3

Characteristics of Stock Market Cycles

\begin{tabular}{|l|c|c|c|c|c|c|}
\hline \hline \multirow{3}{*}{ Phase } & \multicolumn{3}{|c|}{ Amplitude } & \multicolumn{3}{c|}{ Duration } \\
\cline { 2 - 7 } & $\begin{array}{c}\text { Random Walk } \\
\text { (mean) }\end{array}$ & $\begin{array}{c}\text { Actual Data } \\
\text { (mean) }\end{array}$ & $\begin{array}{c}\text { Difference of Means } \\
\text { P-Value }\end{array}$ & $\begin{array}{c}\text { Random Walk } \\
\text { (mean) }\end{array}$ & $\begin{array}{c}\text { Actual Data } \\
\text { (mean) }\end{array}$ & $\begin{array}{c}\text { Difference of Means } \\
\text { P-Value }\end{array}$ \\
\hline \hline Booms & 65 & 74 & 0.01 & 22 & 26 & 0.00 \\
Crashes & $(0.10)$ & $(3.59)$ & & $(0.04)$ & $(1.24)$ & 15 \\
& 55 & 61 & 0.05 & 15 & 0.04 \\
$(0.86)$ & $(3.62)$ & & $(0.03)$ & $(1.26)$ & \\
\hline \hline
\end{tabular}

The table shows the average amplitude and duration of booms and crashes in stock prices for the actual data and for the simulated data, under null hypothesis that stock prices follow a random-walk process. The stock market indexes start in January 1975 and end in June 1999. The filter used identifies 146 stock market cycles. To estimate the average amplitude of booms and crashes under the null hypothesis of a random walk, we first estimate a random walk with drift model for each country. We simulate those models 1,000 times. Since the stock market series for several countries do not span the whole sample, the length of the simulated random walk series for each country is the same as the length of the actual series. Amplitude is expressed in percent, calculated as a deviation from the mid point between the peak and the trough. Duration is expressed in months. Standard errors are in parentheses. 

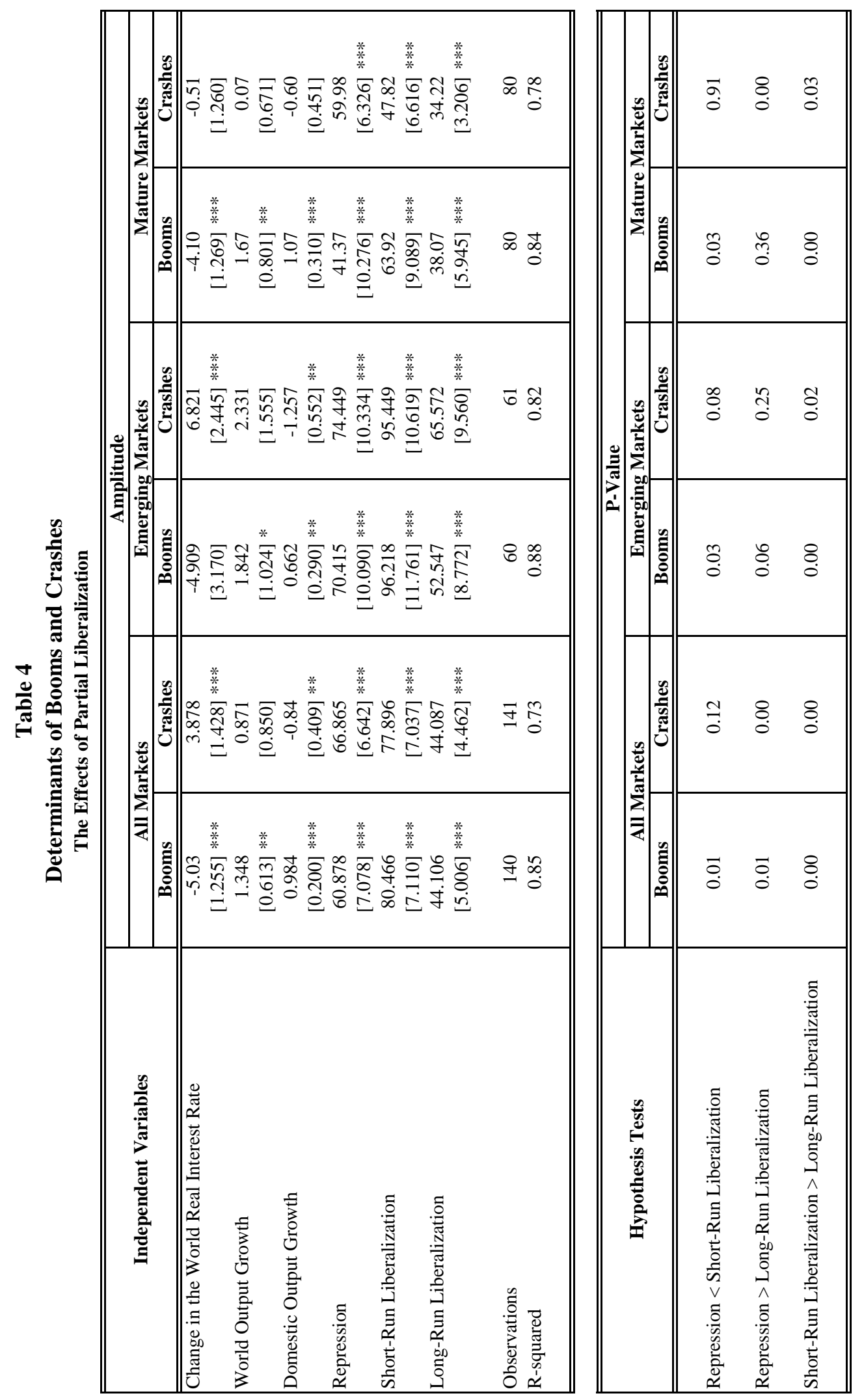

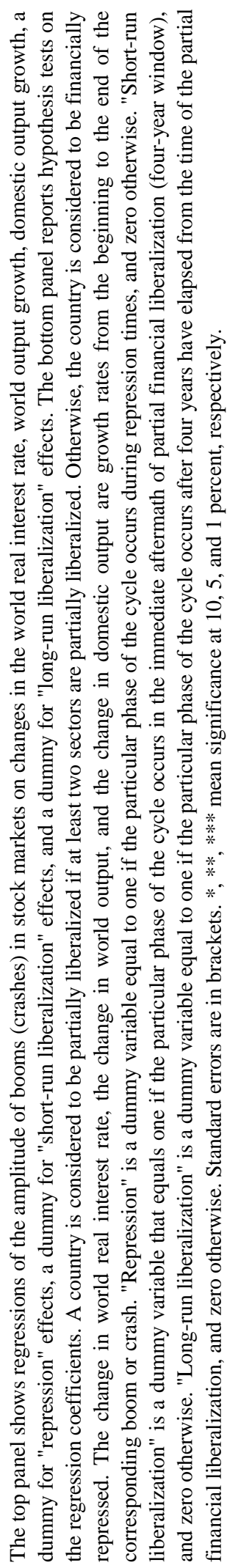


Table 5

Determinants of Booms and Crashes

The Effects of Sequencing

\begin{tabular}{|c|c|c|c|c|c|c|}
\hline \multirow{3}{*}{ Independent Variables } & \multicolumn{6}{|c|}{ Amplitude } \\
\hline & \multicolumn{2}{|c|}{ All Markets } & \multicolumn{2}{|c|}{ Emerging Markets } & \multicolumn{2}{|c|}{ Mature Markets } \\
\hline & Booms & Crashes & Booms & Crashes & Booms & Crashes \\
\hline Change in the World Real Interest Rate & $\begin{array}{l}-4.649 \\
{[1.252] * * *}\end{array}$ & $\begin{array}{c}4.3 \\
{[1.485] * * *}\end{array}$ & $\begin{array}{r}-4.851 \\
{[3.068]}\end{array}$ & $\begin{array}{c}9.506 \\
{[2.2501 * * *}\end{array}$ & $\begin{array}{c}-3.64 \\
{[1329] * * *}\end{array}$ & $\begin{array}{r}-0.57 \\
\end{array}$ \\
\hline World Output Growth & 1.426 & 0.85 & 1.676 & 2.522 & 1.77 & -0.02 \\
\hline & {$[0.613] * *$} & [0.895] & [1.008] & {$[1.467] *$} & {$[0.833] * *$} & [0.737] \\
\hline Domestic Output Growth & 1.102 & -0.847 & 0.905 & -1.455 & 1.08 & -0.60 \\
\hline & {$[0.199] * * *$} & {$[0.426] * *$} & {$[0.277] * * *$} & {$[0.525] * * *$} & {$[0.320] * * *$} & [0.495] \\
\hline Repression & 51.087 & 69.221 & 57.701 & 84.147 & 38.61 & 60.19 \\
\hline & {$[8.127] * * *$} & {$[8.208] * * *$} & {$[11.533] * * *$} & {$[11.446] * * *$} & {$[11.859] * * *$} & {$[8.105] * * *$} \\
\hline Short-Run Liberalization & 80.389 & 56.276 & 98.122 & 44.119 & 57.37 & 54.89 \\
\hline Sector One and Two & {$[10.059] * * *$} & {$[11.098] * * *$} & {$[15.870] * * *$} & {$[16.507] * *$} & {$[13.187] * * *$} & {$[9.726] * * *$} \\
\hline Short-Run Liberalization & -7.951 & 23.229 & -12.258 & 59.247 & -0.71 & -7.10 \\
\hline Sector Two & {$[11.641]$} & {$[13.196] *$} & {$[18.227]$} & {$[19.044] * * *$} & [15.180] & [11.976] \\
\hline Long-Run Liberalization & $\begin{array}{l}40.147 \\
{[5.196] * * *}\end{array}$ & $\begin{array}{c}44.96 \\
{[4.794] * * *}\end{array}$ & $\begin{array}{l}47.606 \\
{[8.595] * * *}\end{array}$ & $\begin{array}{l}63.974 \\
{[8.963] * * *}\end{array}$ & $\begin{array}{c}34.98 \\
{[6.472] * * *}\end{array}$ & $\begin{array}{c}33.58 \\
{[3.564]}\end{array}$ *** \\
\hline Observations & 132 & 133 & 58 & 59 & 74 & 74 \\
\hline R-squared & 0.85 & 0.73 & 0.89 & 0.85 & 0.84 & 0.78 \\
\hline
\end{tabular}

\begin{tabular}{|c|c|c|c|c|c|c|}
\hline \multirow{3}{*}{ Hypothesis Tests } & \multicolumn{6}{|c|}{ P-Value } \\
\hline & \multicolumn{2}{|c|}{ All Markets } & \multicolumn{2}{|c|}{ Emerging Markets } & \multicolumn{2}{|c|}{ Mature Markets } \\
\hline & Booms & Crashes & Booms & Crashes & Booms & Crashes \\
\hline \multicolumn{7}{|l|}{ Repression < Short-Run Liberalization } \\
\hline First Sector & 0.01 & 0.83 & 0.01 & 0.98 & 0.12 & 0.66 \\
\hline Second Sector & 0.01 & 0.17 & 0.02 & 0.10 & 0.09 & 0.88 \\
\hline Repression > Long-Run Liberalization & 0.08 & 0.00 & 0.21 & 0.07 & 0.37 & 0.00 \\
\hline \multicolumn{7}{|l|}{ Short-Run Liberalization > Long-Run Liberalization } \\
\hline First Sector & 0.00 & 0.17 & 0.00 & 0.86 & 0.05 & 0.02 \\
\hline Second Sector & 0.00 & 0.00 & 0.00 & 0.00 & 0.01 & 0.04 \\
\hline
\end{tabular}

This table analizes whether the sucessive liberalizations of the three sectors trigger more unstable financial markets (larger booms and crashes) in the short run. The top panel shows regressions of the amplitude of booms (crashes) in stock markets on the change in the world real interest rate, world output growth, domestic output growth, a dummy for "repression" effects, two dummies for "short-run liberalization" effects, and a dummy for "long-run liberalization" effects. The change in world real interest rate, the change in world output, and the change in domestic output are growth rates from the beginning to the end of the corresponding boom or crash. "Repression" is a dummy variable equal to one if the particular phase of the cycle occurs during repression times, and zero otherwise. "Short-run liberalization sector one and two" is a dummy variable that equals one if the particular phase of the cycle occurs in the immediate aftermath of financial liberalization of the first or second sectors (four-year window), and zero otherwise. "Short-run liberalization sector two" is a dummy variable that equals one if the particular phase of the cycle occurs in the immediate aftermath of financial liberalization of the second sector (four-year window), and zero otherwise. "Long-run liberalization" is a dummy variable that equals one if the particular phase of the cycle occurs after four years have elapsed from the time of financial liberalization of the second sector, and zero otherwise. The bottom panel reports hypothesis tests on the regression coefficients. "Short-run liberalization first (second) sector" corresponds to the test of the null hypothesis that the opening of the first (second) sector does not trigger larger booms and crashes relative to repression times or long-run liberalization, alternatively. If the stock market is liberalized before 1973, only the capital account and the domestic financial sector are being considered in the analysis. Standard errors are in brackets. *, **, *** mean significance at 10, 5, and 1 percent, respectively. 
Table 6

Determinants of Booms and Crashes

The Effects of Sequencing

\begin{tabular}{|c|c|c|c|c|c|c|}
\hline \multirow{3}{*}{ Independent Variables } & \multicolumn{6}{|c|}{ Amplitude } \\
\hline & \multicolumn{2}{|c|}{ All Markets } & \multicolumn{2}{|c|}{ Emerging Markets } & \multicolumn{2}{|c|}{ Mature Markets } \\
\hline & Booms & Crashes & Booms & Crashes & Booms & Crashes \\
\hline Change in the World Real Interest Rate & "-4.706 & 4.37 & -4.756 & 8.079 & -3.85 & -0.10 \\
\hline & {$[1.265] * * *$} & {$[1.518] * * *$} & [3.092] & {$[2.227] * * *$} & {$[1.356] * * *$} & [1.402] \\
\hline World Output Growth & 1.356 & 0.89 & 1.86 & 2.953 & 1.75 & 0.19 \\
\hline & {$[0.619] * *$} & [0.914] & {$[1.073] *$} & {$[1.687] *$} & {$[0.841] * *$} & [0.743] \\
\hline Domestic Output Growth & 1.097 & -0.847 & 0.888 & -1.635 & 1.08 & -0.64 \\
\hline & {$[0.199] * * *$} & {$[0.430] *$} & {$[0.282] * * *$} & {$[0.508] * * *$} & {$[0.323] * * *$} & [0.489] \\
\hline Repression & 51.738 & 69.078 & 56.71 & 82.268 & 39.11 & 58.72 \\
\hline & [8.159] *** & {$[8.287] * * *$} & {$[11.743] * * *$} & {$[11.306] * * *$} & [11.974] *** & {$[8.062] * * *$} \\
\hline Short-Run Liberalization & 81.618 & 56.46 & 97.193 & 45.445 & 56.55 & 58.78 \\
\hline Sector One and Two & {$[10.113] * * *$} & {$[11.244] * * *$} & {$[16.076] * * *$} & {$[15.955] * * *$} & {$[13.546] * * *$} & [9.892] *** \\
\hline First Sector to Open: Capital Account & -9.449 & -3.216 & -26.611 & 64.331 & 7.86 & -21.95 \\
\hline & [13.011] & [16.044] & [23.260] & {$[25.551] * *$} & [15.298] & [13.539] \\
\hline First Sector to Open: Stock Market & -26.004 & -6.09 & -7.518 & 40.558 & -17.65 & -26.94 \\
\hline & {$[20.553]$} & [24.398] & [38.317] & [45.599] & [23.957] & {$[18.863]$} \\
\hline Short-Run Liberalization & -3.94 & 24.453 & -6.473 & 43.828 & 1.20 & 0.52 \\
\hline Sector Two & {$[12.028]$} & {$[13.952] *$} & [19.058] & {$[19.286] * *$} & [15.865] & [12.528] \\
\hline Long-Run Liberalization & $\begin{array}{l}40.749 \\
{[5.218] * * *}\end{array}$ & $\begin{array}{l}44.893 \\
{[4.837] * * *}\end{array}$ & $\begin{array}{l}47.186 \\
{[8.679] * * *}\end{array}$ & $\begin{array}{l}64.876 \\
{[8.788] * * *}\end{array}$ & $\begin{array}{c}35.00 \\
{[6.558] * * *}\end{array}$ & $\begin{array}{c}33.42 \\
{[3.524] * * *}\end{array}$ \\
\hline Observations & 132 & 133 & 58 & 59 & 74 & 74 \\
\hline R-squared & 0.86 & 0.73 & 0.89 & 0.87 & 0.84 & 0.79 \\
\hline
\end{tabular}

\begin{tabular}{|c|c|c|c|c|c|c|}
\hline \multirow{3}{*}{ Hypothesis Tests } & \multicolumn{6}{|c|}{$\overline{P \text { P-Value }}$} \\
\hline & \multicolumn{2}{|c|}{ All Markets } & \multicolumn{2}{|c|}{ Emerging Markets } & \multicolumn{2}{|c|}{ Mature Markets } \\
\hline & Booms & Crashes & Booms & Crashes & Booms & Crashes \\
\hline \multicolumn{7}{|l|}{ Repression < Short-Run Liberalization } \\
\hline Domestic Financial Sector & 0.01 & 0.82 & 0.01 & 0.97 & 0.14 & 0.50 \\
\hline Capital Account & 0.11 & 0.78 & 0.32 & 0.20 & 0.11 & 0.91 \\
\hline Stock Market & 0.44 & 0.75 & 0.22 & 0.47 & 0.50 & 0.89 \\
\hline Repression > Long-Run Liberalization & 0.08 & 0.00 & 0.23 & 0.10 & 0.35 & 0.00 \\
\hline \multicolumn{7}{|c|}{ Short-Run Liberalization > Long-Run Liberalization } \\
\hline Domestic Financial Sector & 0.00 & 0.17 & 0.00 & 0.87 & 0.06 & 0.01 \\
\hline Capital Account & 0.03 & 0.33 & 0.22 & 0.08 & 0.06 & 0.41 \\
\hline Stock Market & 0.26 & 0.42 & 0.15 & 0.33 & 0.44 & 0.53 \\
\hline
\end{tabular}

This table shows whether the short-run effects of liberalization depend on which sector is deregulated first. The top panel shows regressions of the amplitude of booms (crashes) in stock markets on changes in the world real interest rate, world output growth, domestic output growth, a dummy for "repression" effects, two dummies for "shortrun liberalization" effects, a dummy for the capital account opening if this is the first sector to open, a dummy for the stock market opening if this is the first sector to open, and a dummy for "long-run liberalization" effects. The change in world real interest rate, the change in world output, and the change in domestic output are growth rates from the beginning to the end of the corresponding boom or crash. "Repression" is a dummy variable equal to one if the particular phase of a cycle occurs during repression times, and zero otherwise. "Short-run liberalization sector one and two" is a dummy variable that equals one if the particular phase of a cycle occurs in the immediate aftermath of financial liberalization of the first and second sectors (four-year window), and zero otherwise. "Short-run liberalization sector two" is a dummy variable that equals one if the particular phase of the cycle occurs in the immediate aftermath of financial liberalization of the second sector (four-year window), and zero otherwise. "Long-run liberalization" is a dummy variable that equals one if the particular phase of the cycle occurs after four years have elapsed from the time of financial liberalization of the second sector, and zero otherwise. "First sector to open: capital account (stock market)" is a dummy variable equal to one if the first sector to open is the capital account (stock market), and zero otherwise. The bottom panel reports hypothesis tests on the regression coefficients. "Short-run liberalization domestic financial sector (capital account/stock market)" corresponds to the test of the null hypothesis that opening first the domestic financial sector (capital account/stock market) does not trigger larger booms and crashes relative to repression times or long-run liberalization, alternatively. If the stock market is liberalized before 1973, only the capital account and the domestic financial sector are being considered in the analysis. Standard errors are in brackets. *, **, *** mean significance at 10,5 , and 1 percent, respectively. 
Table 7

Financial Liberalization and Institutional Reforms

Panel A

Sequencing

Mature Markets

\begin{tabular}{|c|c|c|c|}
\hline \hline \multirow{2}{*}{ Type of Financial Liberalization } & \multicolumn{2}{|c|}{ Probabilities of Liberalization Conditional on } \\
\cline { 2 - 4 } & $\begin{array}{c}\text { Insider Trading Laws } \\
\text { Existence }\end{array}$ & $\begin{array}{c}\text { Insider Trading Laws } \\
\text { Enforcement }\end{array}$ & Law and Order \\
\hline \hline Partial Liberalization & $36 * *$ & 17 & $44 * * *$ \\
Full Liberalization & $64 * * *$ & $25 *$ & $50 * *$ \\
Hypothesis Test (P-Value) \\
Partial Liberalization = Full Liberalization
\end{tabular}

Emerging Markets

\begin{tabular}{|c|c|c|c|}
\hline \multirow[b]{2}{*}{ Type of Financial Liberalization } & \multicolumn{3}{|c|}{ Probabilities of Liberalization Conditional on } \\
\hline & \begin{tabular}{|c|}
$\begin{array}{c}\text { Insider Trading Laws } \\
\text { Existence }\end{array}$ \\
\end{tabular} & $\begin{array}{c}\text { Insider Trading Laws } \\
\text { Enforcement } \\
\end{array}$ & Law and Order \\
\hline $\begin{array}{l}\text { Partial Liberalization } \\
\text { Full Liberalization }\end{array}$ & $\begin{array}{l}62 * * * \\
77 * * *\end{array}$ & $\begin{array}{l}11 \\
44 * *\end{array}$ & $\begin{array}{l}18 \\
64 * * *\end{array}$ \\
\hline $\begin{array}{l}\text { Hypothesis Test }(\mathrm{P}-\text { Value }) \\
\quad \text { Partial Liberalization = Full Liberalization }\end{array}$ & 0.17 & 0.08 & 0.02 \\
\hline
\end{tabular}

Panel B

Effects of Liberalization and Institutional Reforms on Financial Cycles

\begin{tabular}{|c|c|c|}
\hline \multirow{3}{*}{ Independent Variables } & \multirow{2}{*}{\multicolumn{2}{|c|}{$\begin{array}{c}\text { Amplitude } \\
\text { All Markets }\end{array}$}} \\
\hline & & \\
\hline & Booms & Crashes \\
\hline Change in the Real Interest Rate & $\begin{array}{c}-4.496 \\
{[1.245] * * *}\end{array}$ & $\begin{array}{c}4.05 \\
{[1.442] \text { *** }}\end{array}$ \\
\hline World Output Growth & $\begin{array}{c}1.498 \\
{[0.609] * *}\end{array}$ & $\begin{array}{r}1.033 \\
{[0.863]}\end{array}$ \\
\hline Domestic Output Growth & $\begin{array}{c}0.963 \\
{[0.199] * * *}\end{array}$ & $\begin{array}{c}-0.876 \\
{[0.415] * *}\end{array}$ \\
\hline "Repression Times" Dummy & $\begin{array}{l}63.696 \\
{[7.376] * * *}\end{array}$ & $\begin{array}{l}69.188 \\
{[7.176] * * *}\end{array}$ \\
\hline Short-Run Dummy & $\begin{array}{l}83.329 \\
{[8.245] \text { *** }}\end{array}$ & $\begin{array}{l}80.368 \\
{[8.558] * * *}\end{array}$ \\
\hline Long-Run Dummy & $\begin{array}{l}53.259 \\
{[7.781] * * *}\end{array}$ & $\begin{array}{l}50.923 \\
{[8.139] * * *}\end{array}$ \\
\hline Law and Order & $\begin{array}{l}-18.316 \\
{[6.178] * * *}\end{array}$ & $\begin{array}{r}-8.984 \\
{[7.005]}\end{array}$ \\
\hline Insider Trading Laws & & \\
\hline Existence & $\begin{array}{r}2.159 \\
{[7.005]}\end{array}$ & $\begin{array}{r}-0.627 \\
{[7.821]}\end{array}$ \\
\hline Enforcement & $\begin{array}{r}0.543 \\
{[7.560]}\end{array}$ & $\begin{array}{r}-1.732 \\
{[8.422]}\end{array}$ \\
\hline Observations & 140 & 141 \\
\hline R-squared & 0.86 & 0.73 \\
\hline
\end{tabular}

Panel A shows the probability of financial liberalization conditional on the existence and enforcement of insider trading laws and on the dummy for law and order. Panel B reports the regression reported in Table 4 with the inclusion of the institutional variables: law and order, existence of insider trading laws, and enforcement of insider trading laws. "Law and order" is a dummy variable that equals one in periods in which there is a "permanent" improvement in the International Country Risk Guide's index of law and order or the index is at its highest level. The improvement periods in this index are characterized by at least one point increase in the index from its two-year period average, and the maintainance of the index above this average for at least another two years. "Insider trading laws" are dummy variables that equal one after the existence or enforcement of those laws. The data come from Bhattacharya and Daouk (2000). See Appendix Table 3. Standard errors are in brackets. *,**,*** mean significance at 10,5 , and 1 percent, respectively. 
Figure 1

Index of Financial Liberalization

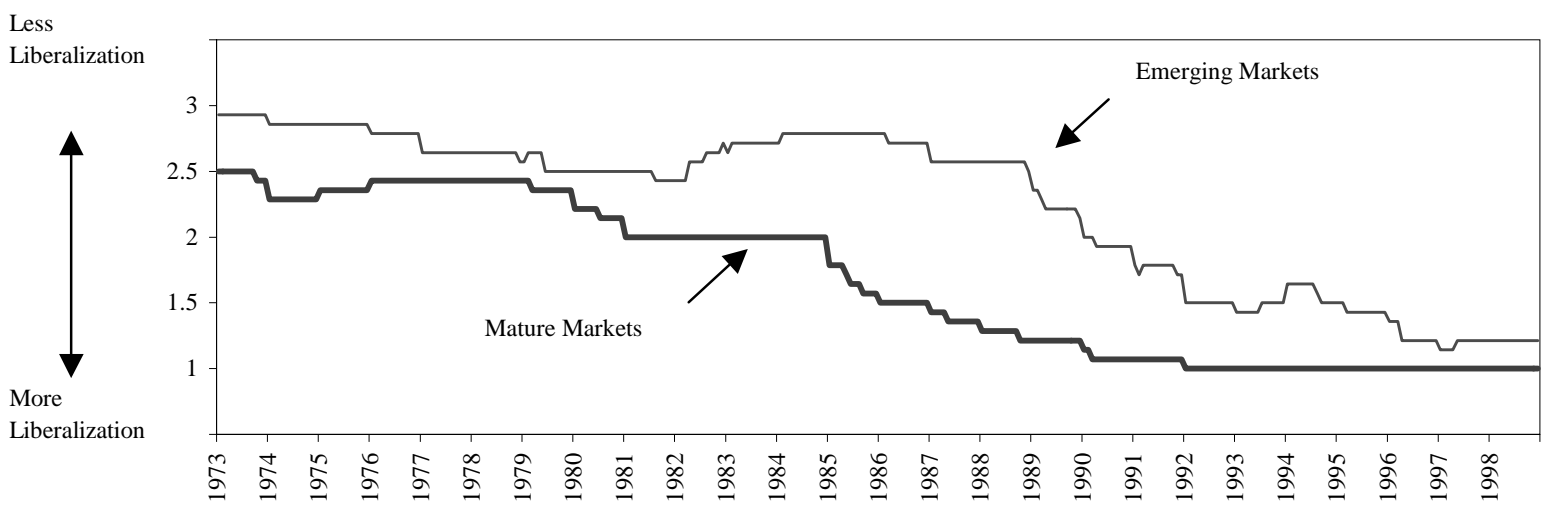

The index of financial liberalization jointly evaluates the liberalization of the capital account, the domestic financial sector, and the stock market. The index is a cross-country average. The value three means repression, two means partial liberalization, and one means full liberalization. Mature markets include: Canada, Denmark, Finland, France, Germany, Ireland, Italy, Japan, Norway, Portugal, Spain, Sweden, United Kingdom, and United States. Emerging markets include: Argentina, Brazil, Chile, Colombia, Hong Kong, Indonesia, Korea, Malaysia, Mexico, Peru, Philippines, Taiwan, Thailand, and Venezuela. 
Figure 2

Indexes of Financial Liberalization by Sector

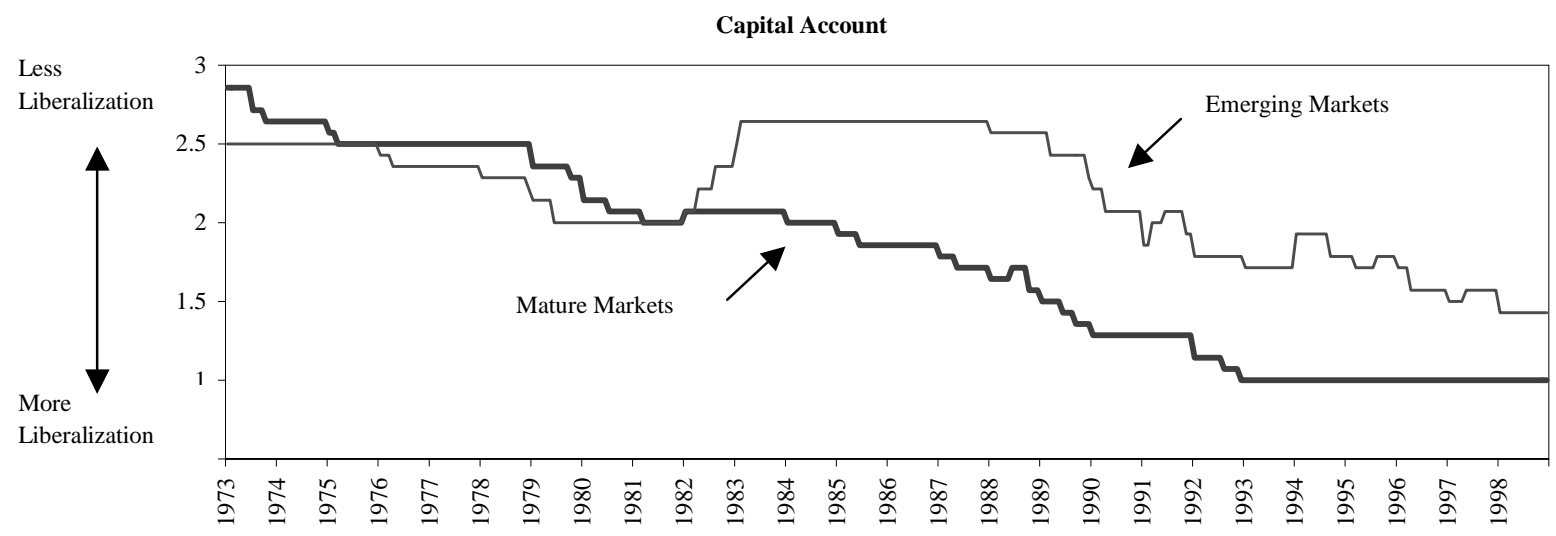

Domestic Financial Sector
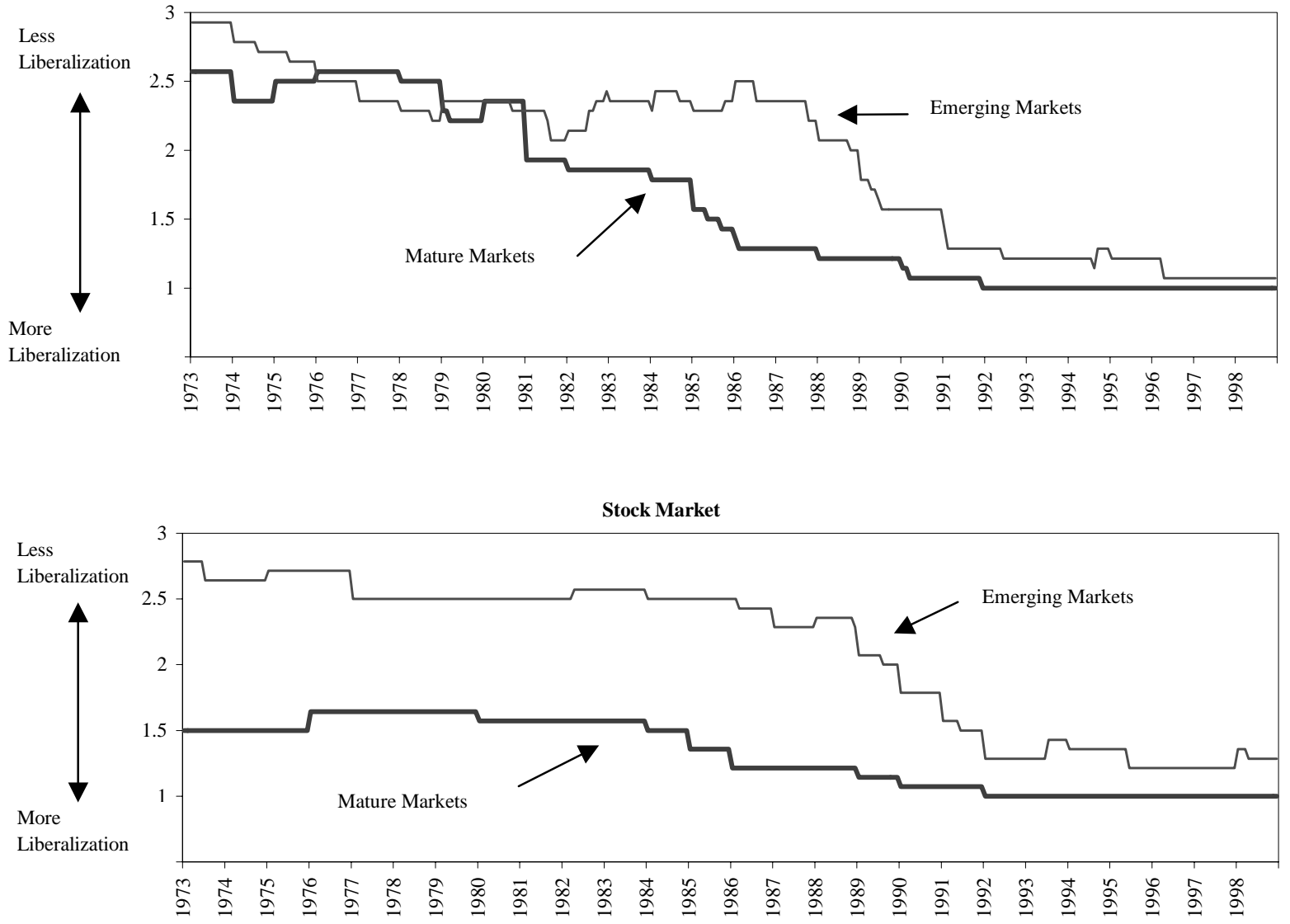

The three indexes evaluate separately the liberalization of the capital account, the domestic financial sector, and the stock market. The indexes are a cross-country average. The value three means repression, two means partial liberalization, and one means full liberalization. Mature markets include: Canada, Denmark, Finland, France, Germany, Ireland, Italy, Japan, Norway, Portugal, Spain, Sweden, United Kingdom, and United States. Emerging markets include: Argentina, Brazil, Chile, Colombia, Hong Kong, Indonesia, Korea, Malaysia, Mexico, Peru, Philippines, Taiwan, Thailand, and Venezuela. 
Figure 3

\section{The Sequencing of Financial Liberalization}
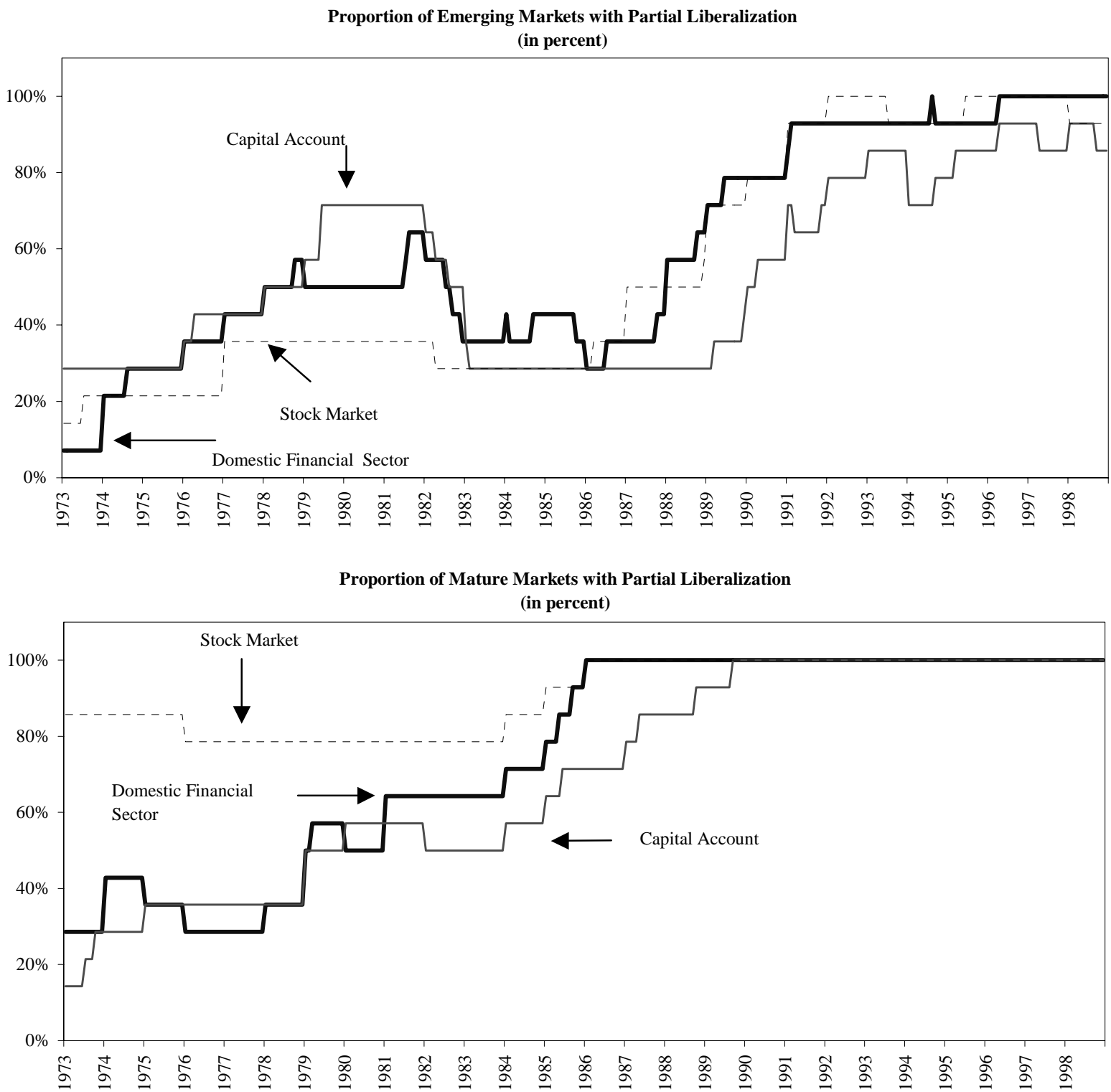

The panels show the proportion of countries with (at least partially) liberalized capital account, domestic financial sector, and stock market. Mature markets include: Canada, Denmark, Finland, France, Germany, Ireland, Italy, Japan, Norway, Portugal, Spain, Sweden, United Kingdom, and United States. Emerging markets include: Argentina, Brazil, Chile, Colombia, Hong Kong, Indonesia, Korea, Malaysia, Mexico, Peru, Philippines, Taiwan, Thailand, and Venezuela. 

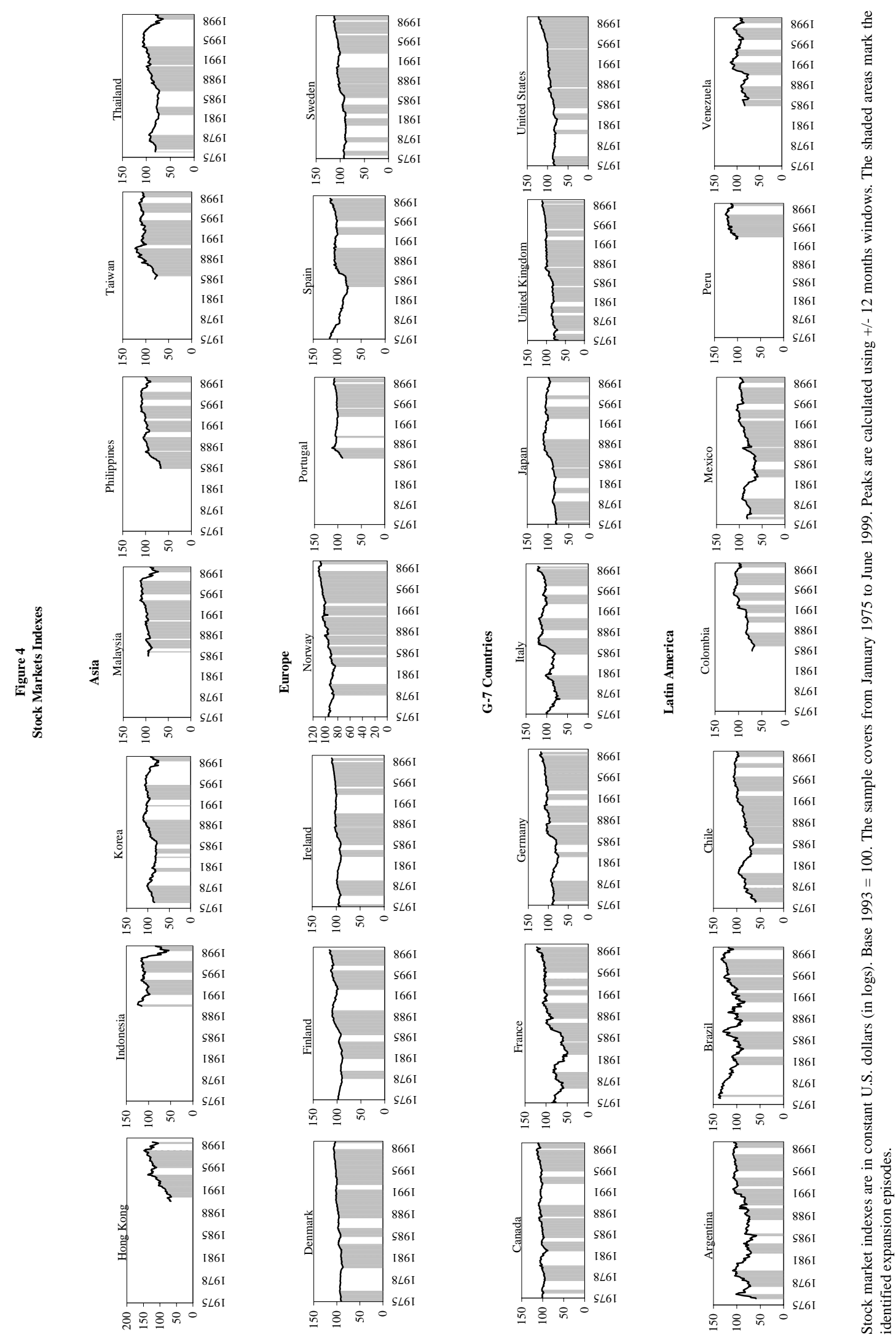
Figure 5

Frequency Distribution of the Amplitude and Duration of Stock Market Booms and Crashes

Amplitude of Booms

Actual

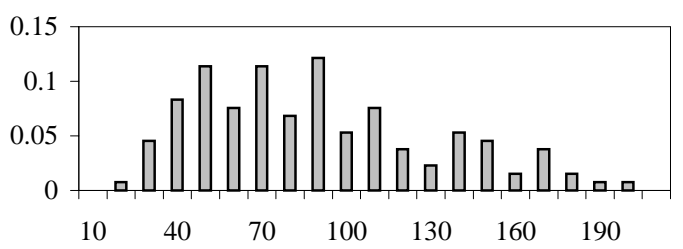

Random Walk

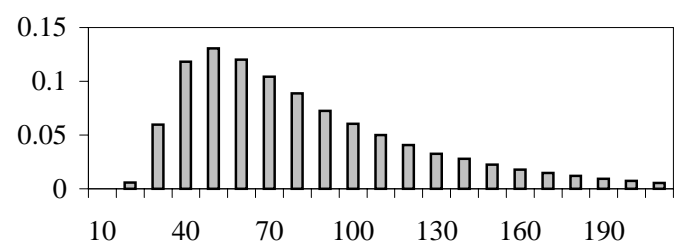

Two-sample Kolmogorov-Smirnov test for equality of distribution functions: P-value 0.01

Amplitude of Crashes

Actual

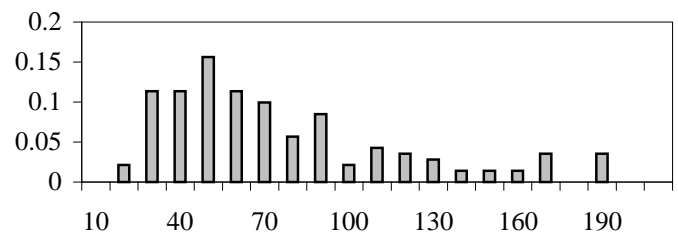

Random Walk

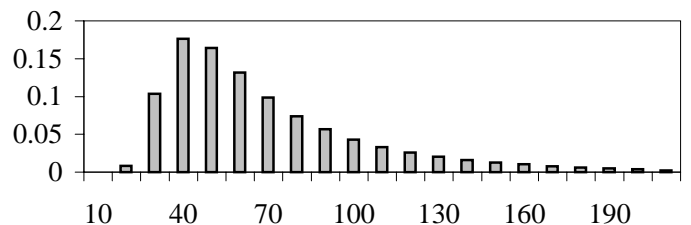

Two-sample Kolmogorov-Smirnov test for equality of distribution functions: P-value 0.10

Duration of Booms

Actual

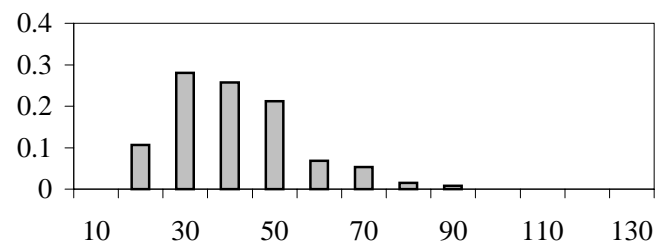

Random Walk

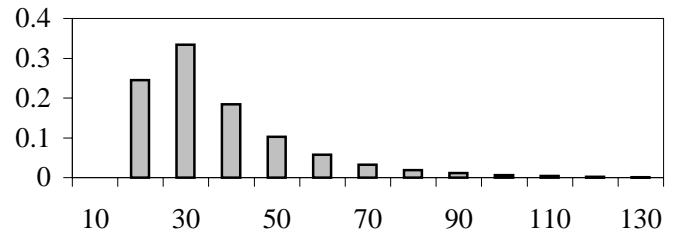

Two-sample Kolmogorov-Smirnov test for equality of distribution functions: P-value 0.00

Duration of Crashes

Actual

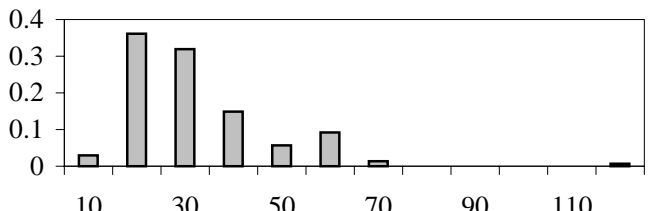

Random Walk

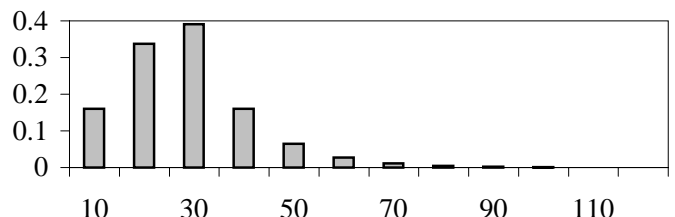

Two-sample Kolmogorov-Smirnov test for equality of distribution functions: P-value 0.18

The figures report the frequency distribution of the amplitude and duration of booms and crashes for the actual and simulated data, assuming random walk processes with drift. The horizontal axis in each figure shows the size or the duration of booms and crashes, the vertical axis shows the frequencies in percent. The Kolmogorov-Smirnov test is used to evaluate the null hypothesis of equality of the frequency distribution of the amplitude and duration of booms and crashes in the actual and generated data. 
Figure 6

\section{Characteristics of Regional Cycles}

Emerging Markets

\begin{tabular}{|l|c|c|c|c|}
\hline \hline \multirow{2}{*}{ Phase } & \multicolumn{2}{|c|}{ Asia } & \multicolumn{2}{c|}{ Latin America } \\
\cline { 2 - 5 } & Amplitude & Duration & Amplitude & Duration \\
\hline \hline Booms & 75 & 24 & 102 & 23 \\
Crashes & 60 & 18 & 86 & 16 \\
\hline \hline
\end{tabular}

Mature Markets

\begin{tabular}{|l|c|c|c|c|}
\hline \hline \multirow{2}{*}{ Phase } & \multicolumn{2}{|c|}{ Europe } & \multicolumn{2}{c|}{ G-7 } \\
\cline { 2 - 5 } & Amplitude & Duration & Amplitude & Duration \\
\hline \hline Booms & 72 & 29 & 53 & 28 \\
Crashes & 51 & 21 & 37 & 16 \\
\hline \hline
\end{tabular}

\section{The Regional Cycles}

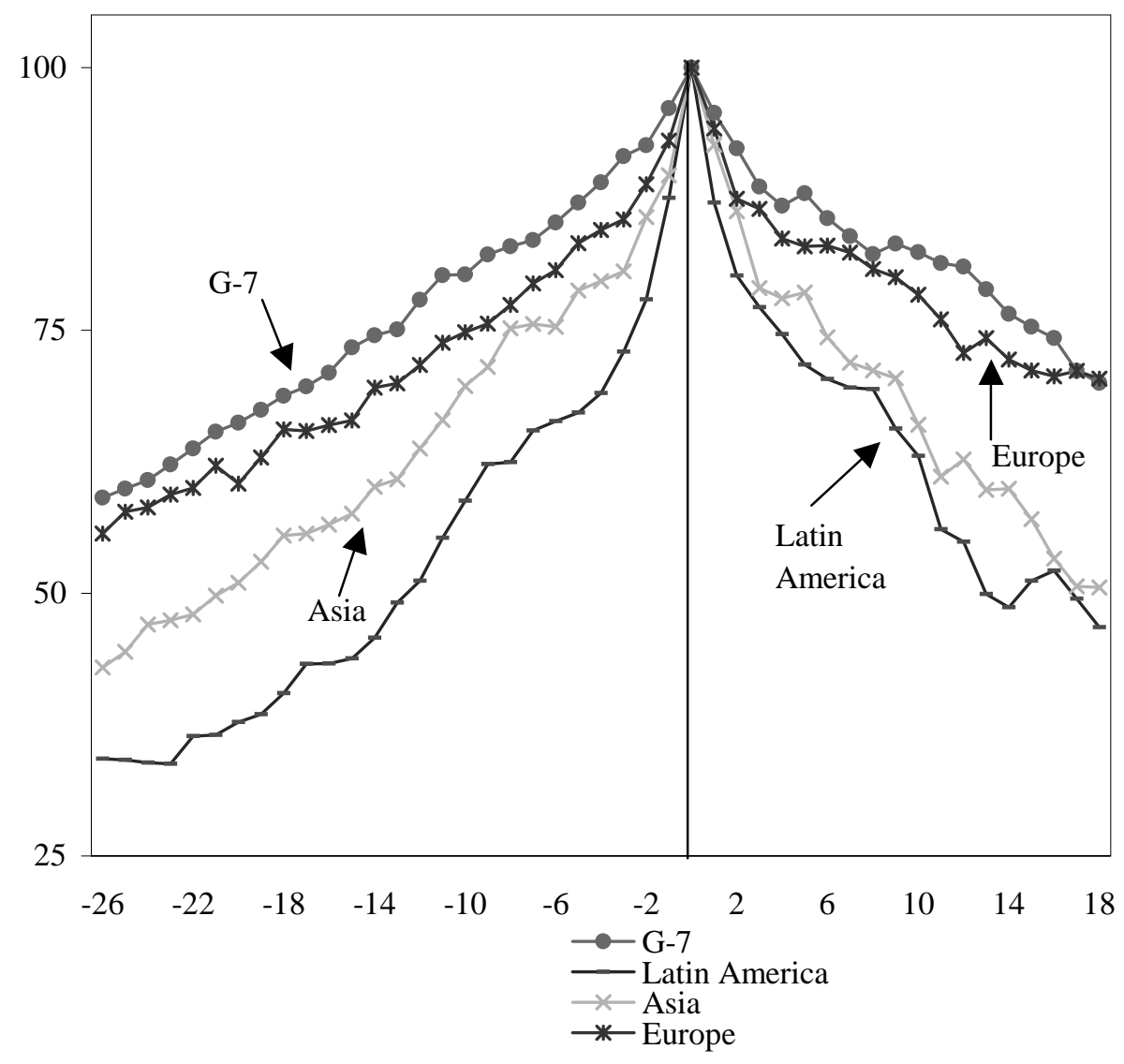

The table and figure show the average cycle per region. The sample starts in January 1975 and ends in June 1999. The total number of cycles per region is as follows: 28 for Asia; 35 for Europe; 44 for G-7; and 39 for Latin America. In the top panel, duration is expressed in months while amplitude is expressed in percent; it is calculated as a deviation from the mid point between the peak and the trough. 


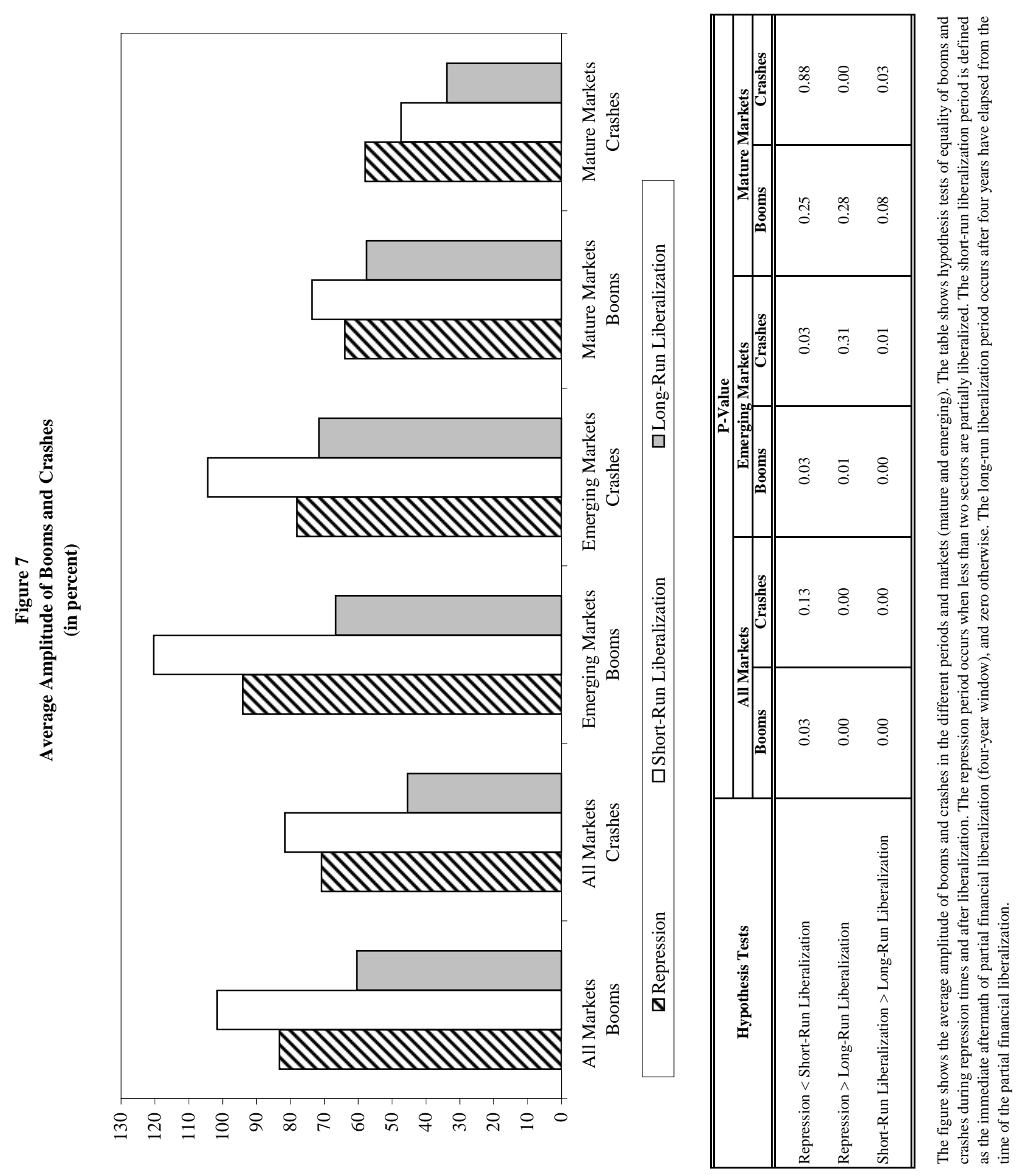




\section{Appendix Table 1 \\ Criteria to Define Liberalization Periods}

Criteria for Full Liberalization corporations

\section{Capital Account}

Multiple exchange rates and other restrictions

Banks and corporations are allowed to borrow abroad mostly freely. They may need to inform the authorities, but the authorization is granted almost automatically. Reserve requirements might be in place but are lower than 10 percent. The required minimum maturity is not longer than two years.

And

Criteria for Partial Liberalization

Borrowing abroad by banks and corporations

There are no special exchange rates for either current account or capital account transactions. There are no restrictions to capital outflows. might be between 10 and 50 percent. The required minimum maturity might be between two and five years. There might be some caps in borrowing and certain restrictions to specific sectors.

Or

Multiple exchange rates and other There are special exchange rates for current account and capital account transactions. There might be some restrictions restrictions to capital outflows.

Criteria for No Liberalization

Borrowing abroad by banks and corporations

Banks and corporations are mostly not allowed to borrow abroad. Reserve requirements might be higher than 50 percent. The required minimum maturity might be longer than five years. There might be caps in borrowing and heavy restrictions to certain sectors.

Or

Multiple exchange rates and other There are special exchange rates for current account and capital account transactions. There might be restrictions restrictions to capital outflows.

\begin{tabular}{ll} 
& \multicolumn{1}{c}{ Domestic Financial Sector } \\
\hline \hline Criteria for Full Liberalization & There are no controls (ceilings and floors) on interest rates. \\
\hline Lending and borrowing interest rates & $\begin{array}{l}\text { And } \\
\text { There are likely no credit controls (subsidies to certain sectors or certain credit allocations). Deposits in } \\
\text { foreign currencies are likely permitted. }\end{array}$ \\
Other indicators & $\begin{array}{l}\text { There are controls in either lending or borrowing rates (ceilings or floors). } \\
\text { And }\end{array}$ \\
\hline Lending and borrowing interest rates & $\begin{array}{l}\text { There might be controls in the allocation of credit controls (subsidies to certain sectors or certain credit } \\
\text { allocations). Deposits in foreign currencies might not be permitted. }\end{array}$ \\
Criteria for No Liberalization & There are controls in lending rates and borrowing rates (ceilings and floors). \\
\hline Lending and borrowing interest rates & And \\
Other indicators & $\begin{array}{l}\text { There are likely controls in the allocation of credit controls (subsidies to certain sectors or certain credit } \\
\text { allocations). Deposits in foreign currencies are likely not permitted. }\end{array}$ \\
\hline
\end{tabular}

Criteria for Full Liberalization

Acquisition by foreign investors

Repatriation of capital, dividends, and interest

Criteria for Partial Liberalization Acquisition by foreign investors

Repatriation of capital, dividends, and interest

Criteria for No Liberalization

Acquisition by foreign investors

Repatriation of capital, dividends, and interest

This table describes the criteria used to determine whether the capital account, the domestic financial sector, and the stock market are fully or partially liberalized.

\section{Stock Market}

Foreign investors are allowed to hold domestic equity without restrictions.

And

Capital, dividends, and interest can be repatriated freely within two years of the initial investment.

Foreign investors are allowed to hold up to 49 percent of each company's outstanding equity. There might be restrictions to participate in certain sectors. There might be indirect ways to invest in the stock market, like through country funds.

Or

Capital, dividends, and interest can be repatriated, but typically not before two and not after five years of the initial investment.

Foreign investors are not allowed to hold domestic equity.

Capital, dividends, and interest can be repatriated, but not before five years of the initial investment. 


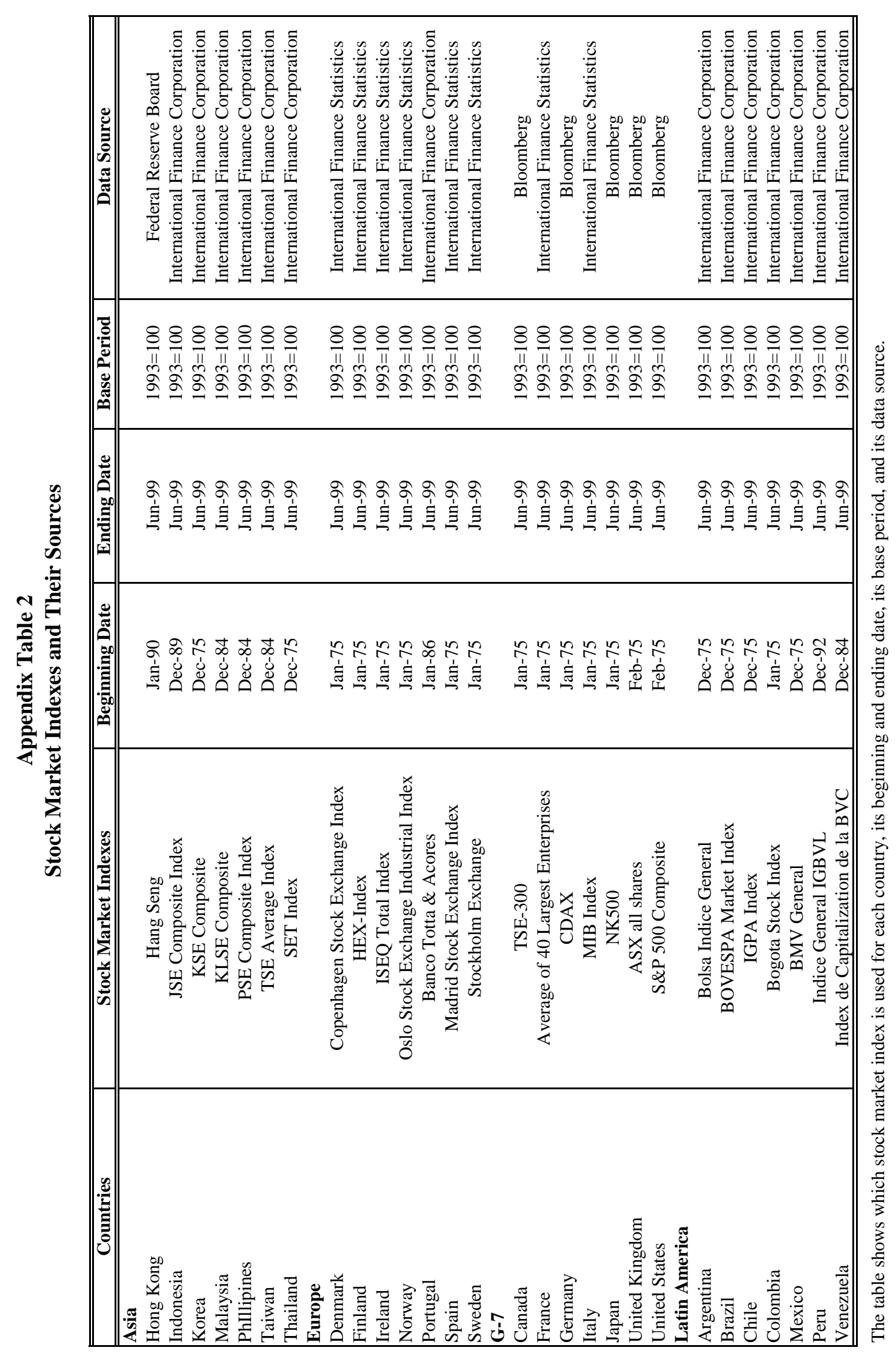


Appendix Table 3

Institutional Reforms

\begin{tabular}{|c|c|c|c|}
\hline Countries & $\begin{array}{c}\text { Index of Law and Order } \\
\text { (1) }\end{array}$ & $\begin{array}{c}\text { Insider Trading Laws } \\
\text { Existence } \\
(2) \\
\end{array}$ & $\begin{array}{c}\text { Insider Trading Laws } \\
\text { Enforcement } \\
(3) \\
\end{array}$ \\
\hline \begin{tabular}{|l} 
Asia \\
Hong Kong \\
Indonesia \\
Korea \\
Malaysia \\
Philippines \\
Taiwan \\
Thailand \\
Europe \\
Denmark \\
Finland \\
Ireland \\
Norway \\
Portugal \\
Spain \\
Sweden \\
G-7 \\
Canada \\
France \\
Germany \\
Italy \\
Japan \\
United Kingdom \\
United States \\
Latin America \\
Argentina \\
Brazil \\
Chile \\
Colombia \\
Mexico \\
Peru \\
Venezuela
\end{tabular} & $\begin{array}{c}\text { Sep-93 } \\
\text { Jun-91 } \\
\text { Oct-91 } \\
\text { Apr-93 } \\
\text { Jul-92 } \\
\text { No Change } \\
\text { Apr-88, Aug-92 } \\
\text { Highest Level (whole sample) } \\
\text { Highest Level (whole sample) } \\
\text { Sep-89, Apr-96 } \\
\text { Highest Level (whole sample) } \\
\text { Oct-94 } \\
\text { Dec-91 } \\
\text { Highest Level (whole sample) } \\
\text { Highest Level (whole sample) } \\
\text { Jan-92 } \\
\text { Highest Level (whole sample) } \\
\text { Aug-95 } \\
\text { Jul-92 } \\
\text { Sept-89, Jan-92 } \\
\text { Highest Level (whole sample) } \\
\text { Dec-92 } \\
\text { No Change } \\
\text { Apr-94 } \\
\text { Mar-94 } \\
\text { No Change } \\
\text { No Change }\end{array}$ & $\begin{array}{c}1991 \\
1991 \\
\mathrm{n} / \mathrm{a} \\
1973 \\
1982 \\
1988 \\
1984 \\
\\
1991 \\
1989 \\
1990 \\
1985 \\
1986 \\
1994 \\
1971 \\
\\
1966 \\
1967 \\
1994 \\
1991 \\
1988 \\
1980 \\
1934 \\
\\
1991 \\
1976 \\
1981 \\
1990 \\
1975 \\
1991 \\
1998\end{array}$ & $\begin{array}{c}1994 \\
1996 \\
\mathrm{n} / \mathrm{a} \\
1996 \\
\text { No } \\
1989 \\
1993 \\
\\
1996 \\
1993 \\
\text { No } \\
1990 \\
\text { No } \\
1998 \\
1990 \\
\\
1976 \\
1975 \\
1995 \\
1996 \\
1990 \\
1981 \\
1961 \\
\\
1995 \\
1978 \\
1996 \\
\text { No } \\
\text { No } \\
1994 \\
\text { No }\end{array}$ \\
\hline
\end{tabular}

Column (1) reports the dates in which there is a "permanent" improvement in the International Country Risk Guide's index of law and order. In this index, law and order are assessed separately, with each sub-component comprising zero to three points. The law sub-component is an assessment of the strength and impartiality of the legal system, while the order sub-component is an assessment of popular observance of the law. The improvement periods in this index are characterized by at least one point increase in the index from its two-year period average, and the maintainance of the index above this average for at least another two years. This column also shows those countries for which the index of law and order was at its highest level during all the sample. "No change" corresponds to no permanent changes in the index. Columns (2) and (3) come from Bhattacharya and Daouk (2000). The columns report, respectively, the dates when insider trading laws are aproved and when the first prosecution under these laws occurs. The authors surveyed stock market participants and national regulators to obtain the answers. "n/a" means not available. "No" means that there is no enforcement of insider trading laws. 


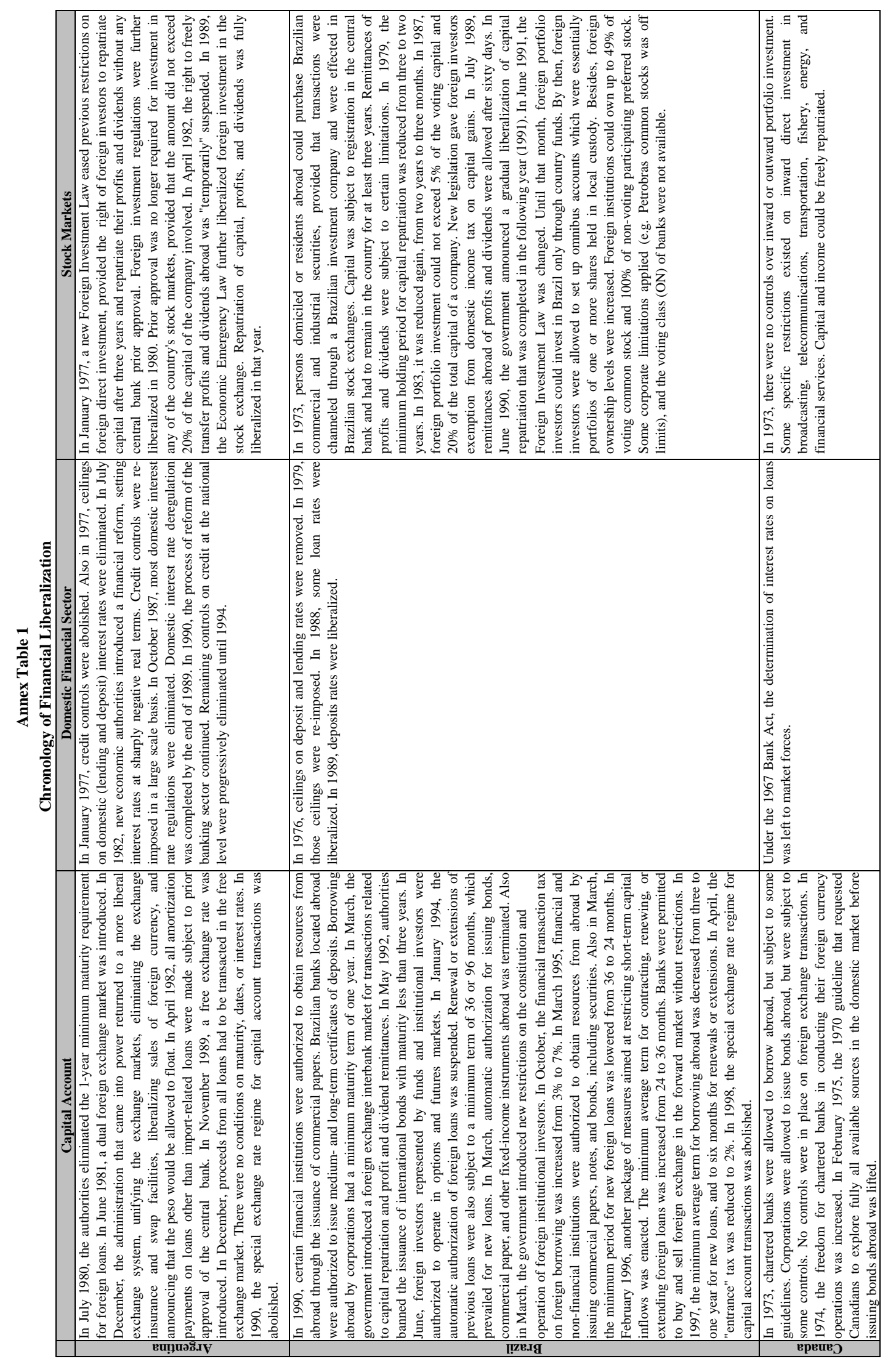




\begin{tabular}{|c|c|c|}
\hline 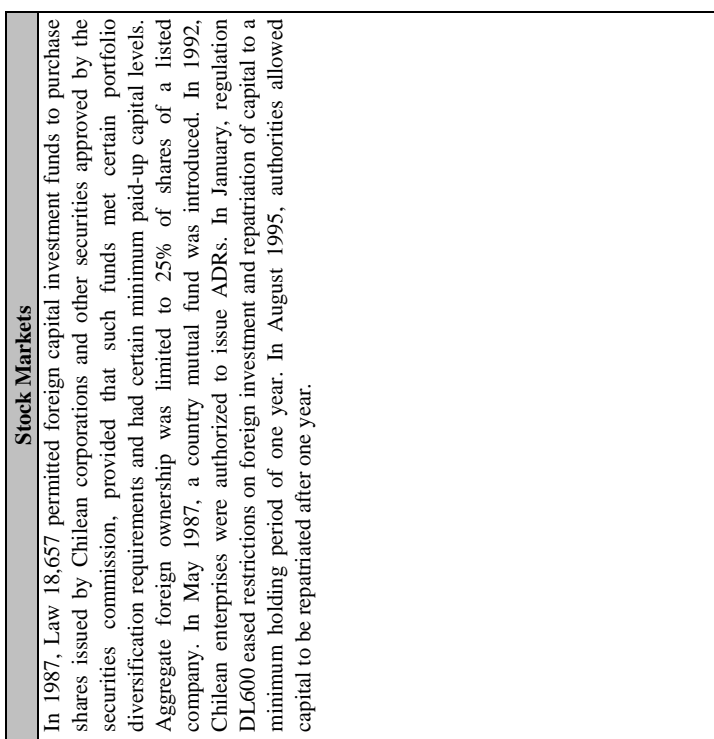 & 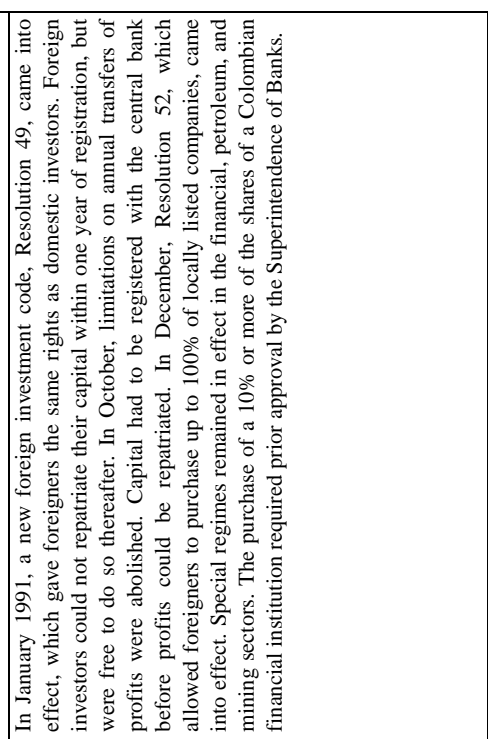 & 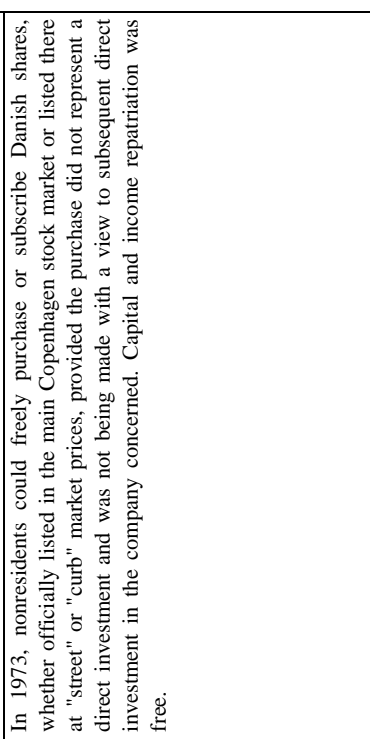 \\
\hline 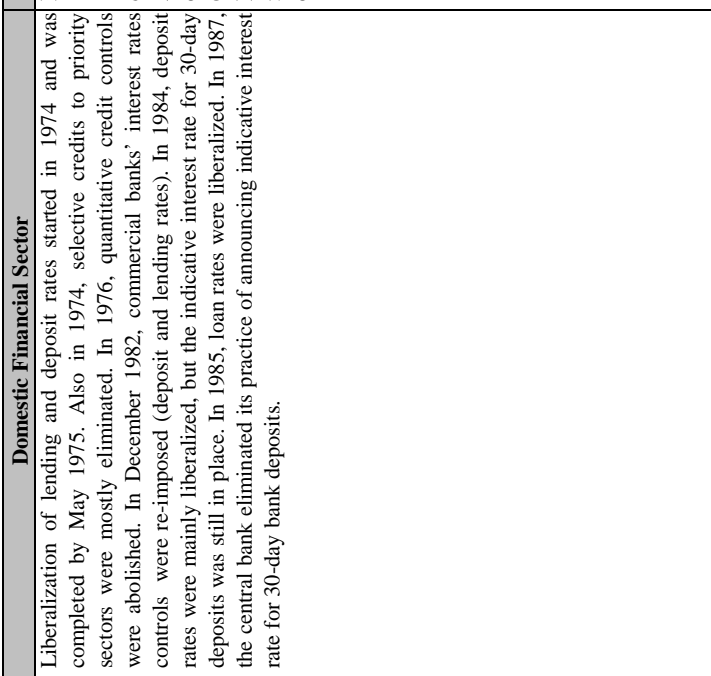 & 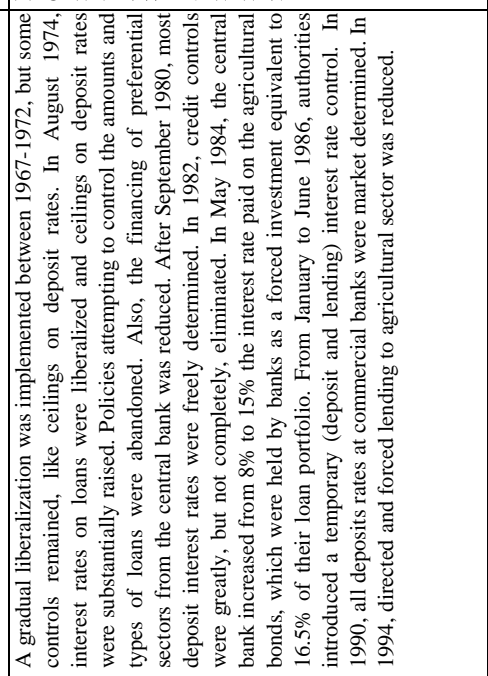 & 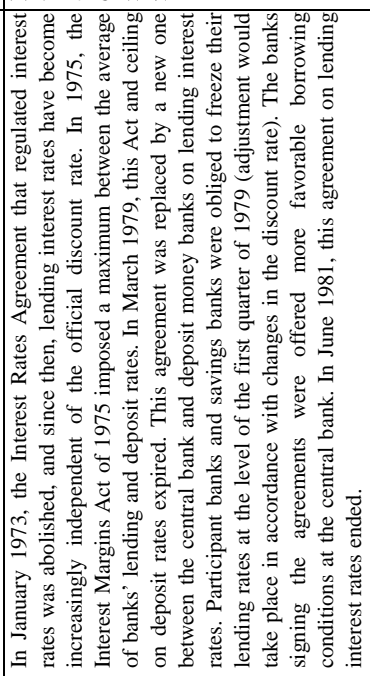 \\
\hline 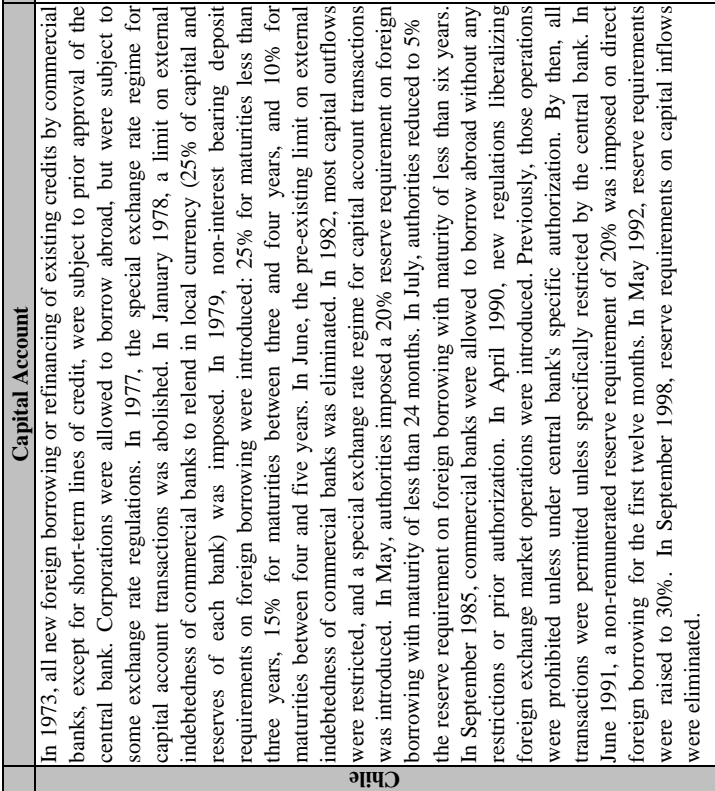 & 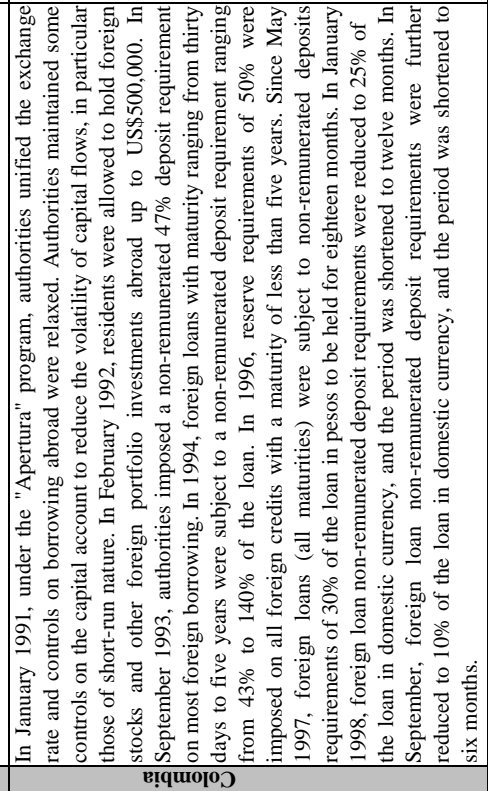 & 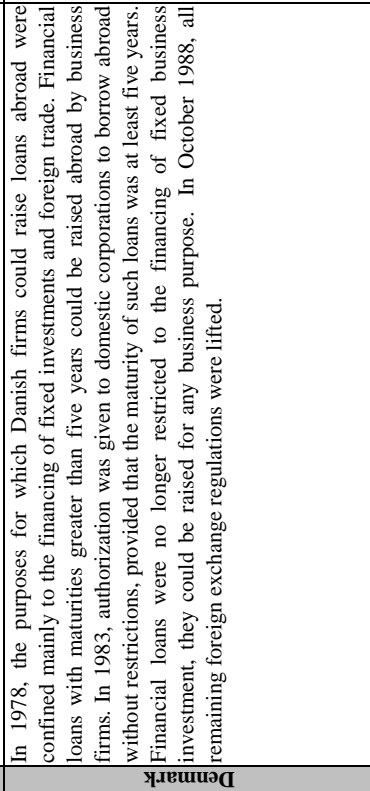 \\
\hline
\end{tabular}




\begin{tabular}{|c|c|c|}
\hline 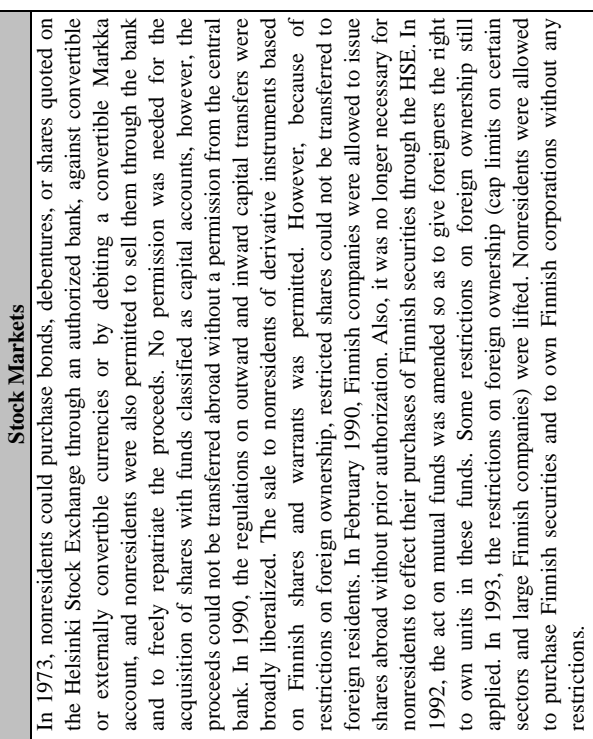 & 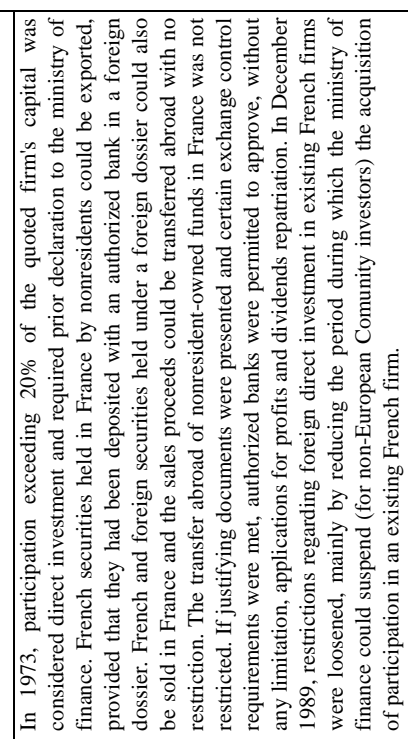 & 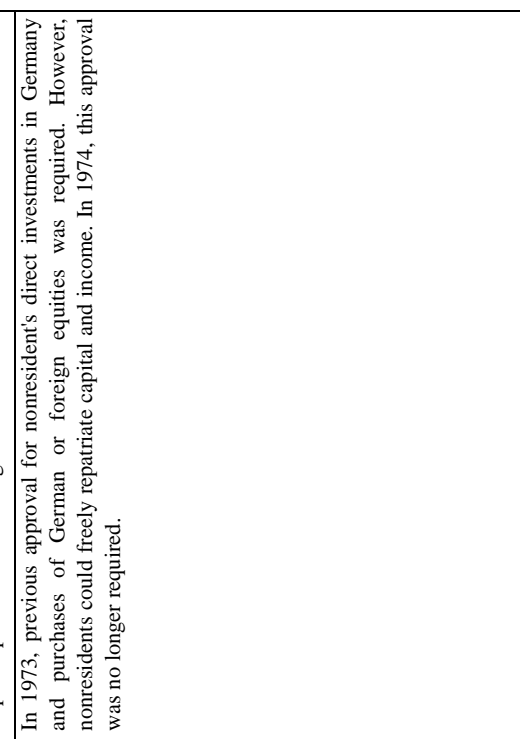 \\
\hline 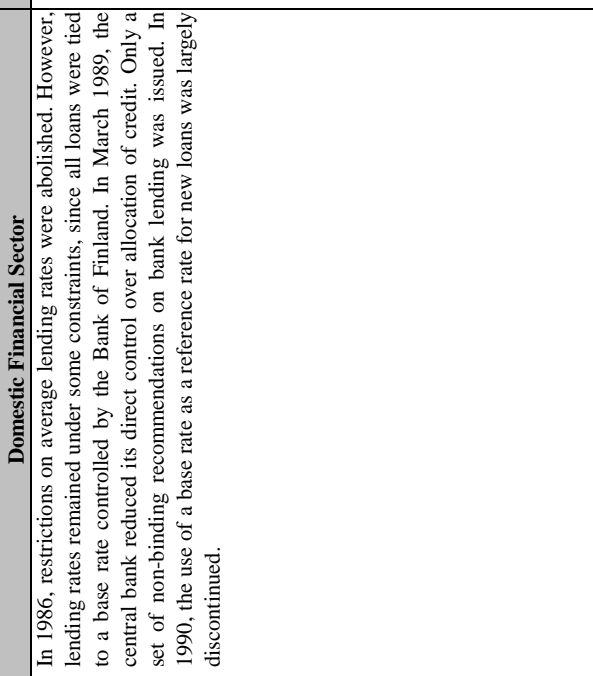 & 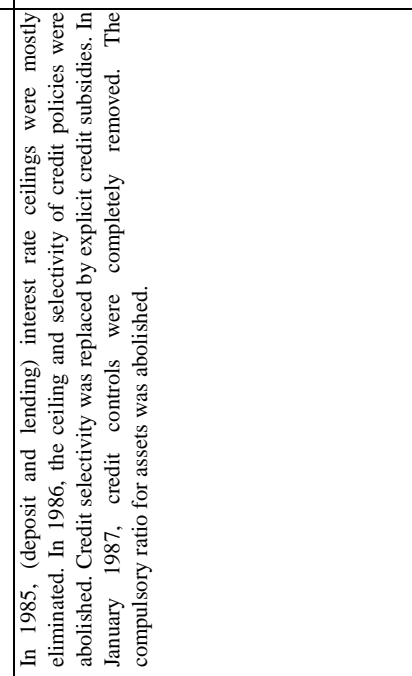 & 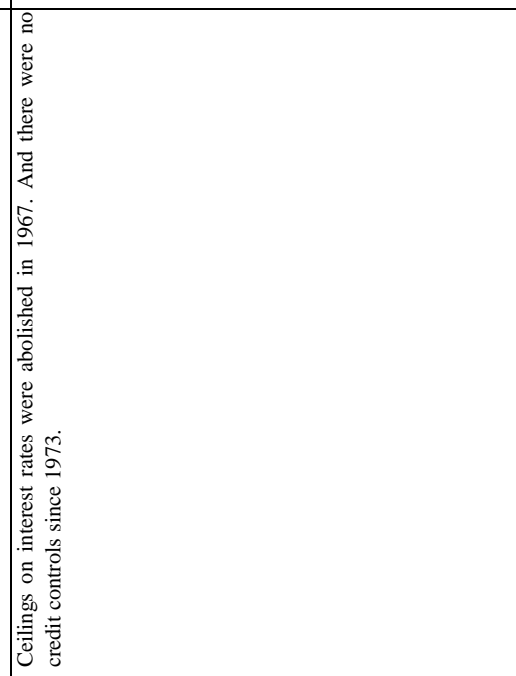 \\
\hline 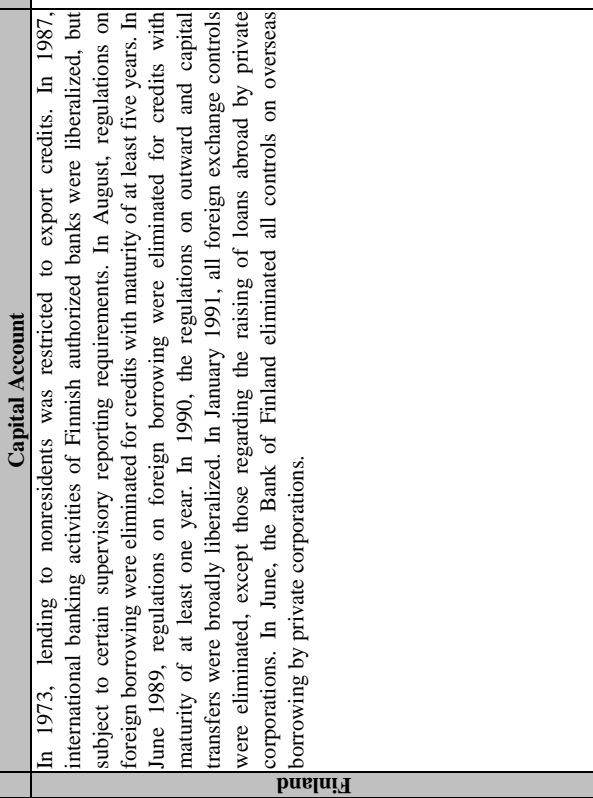 & 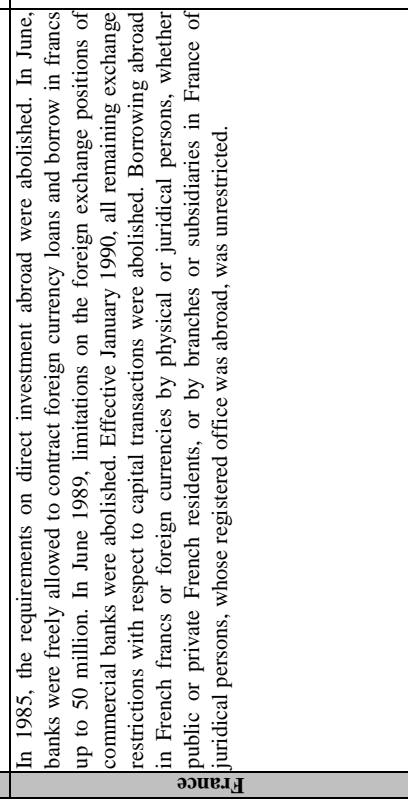 & 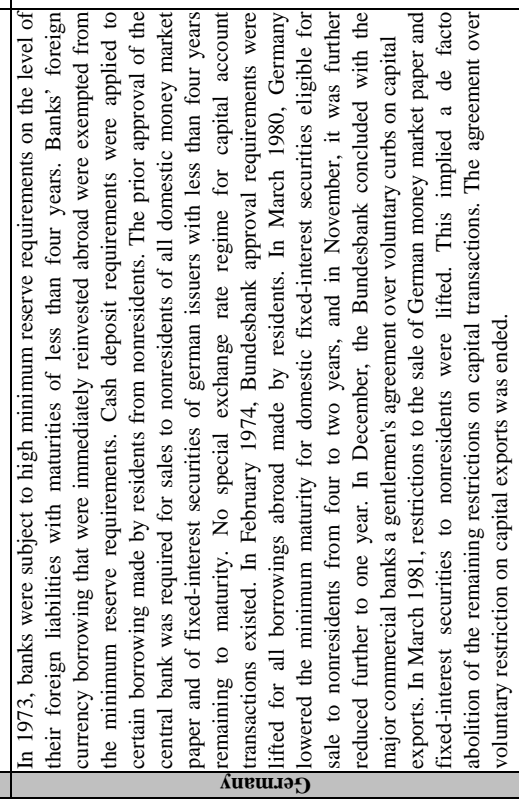 \\
\hline
\end{tabular}




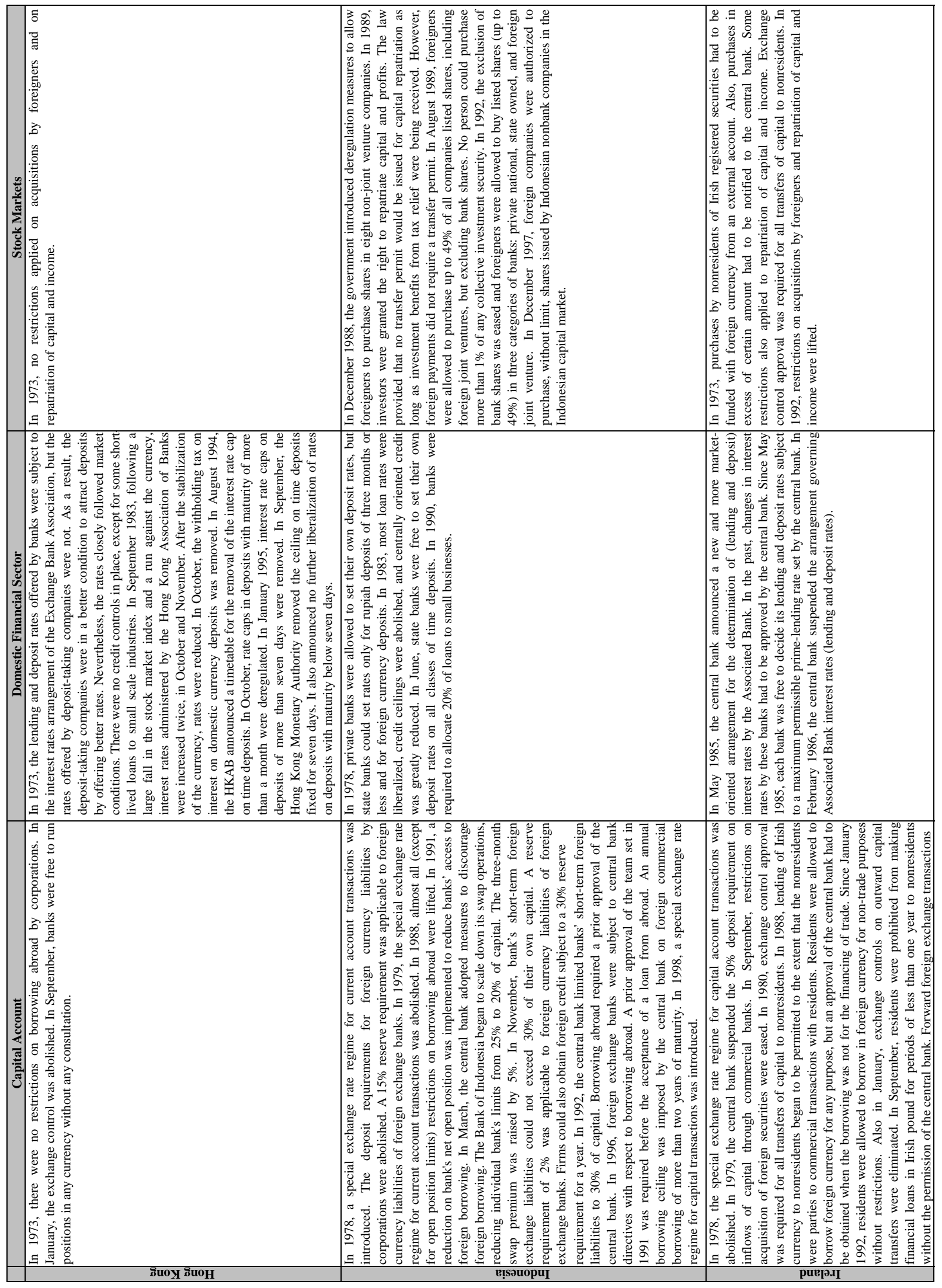




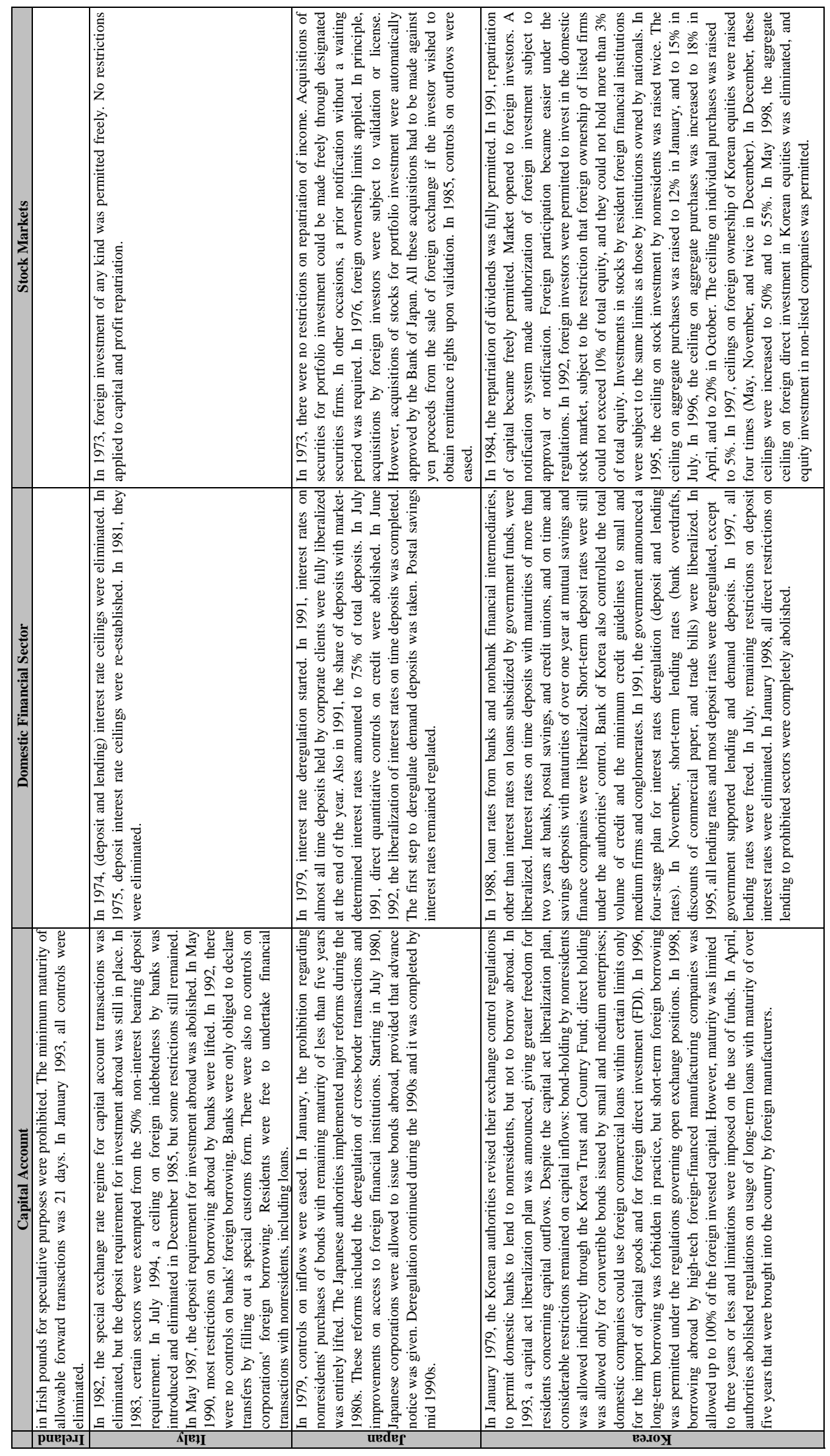




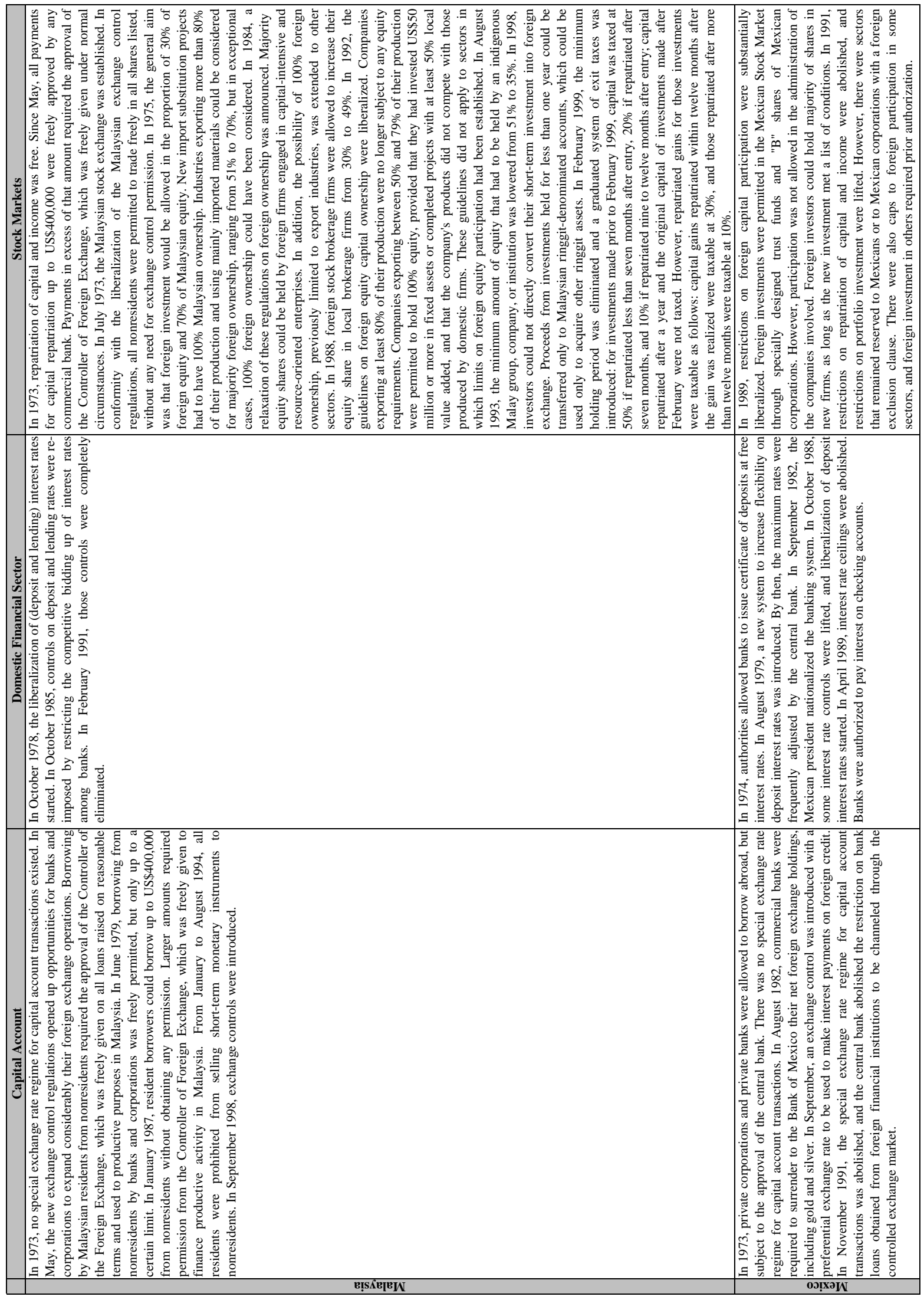




\begin{tabular}{|c|c|c|c|}
\hline 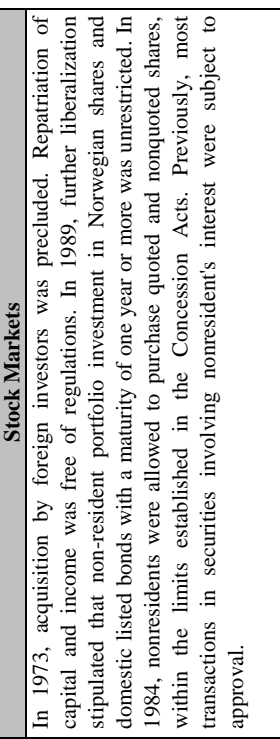 & 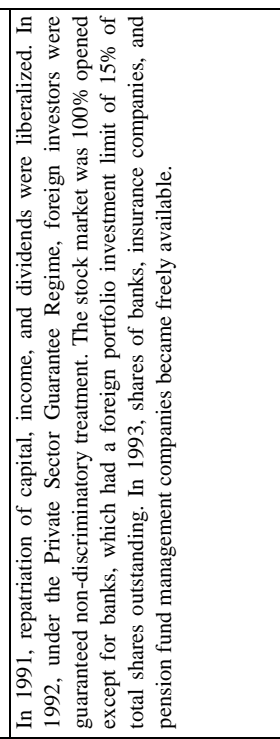 & 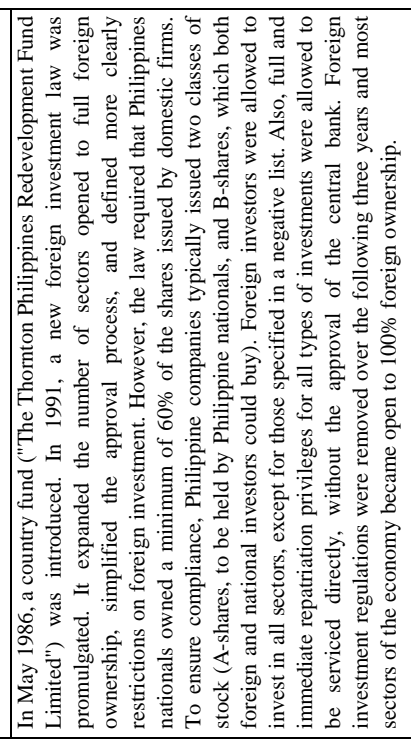 & 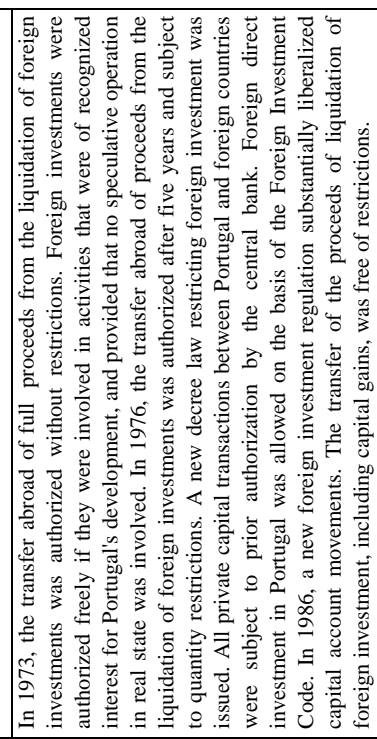 \\
\hline 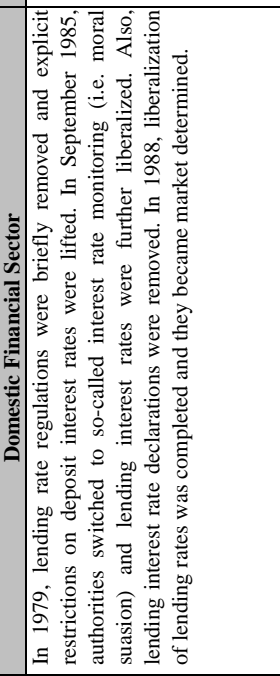 & 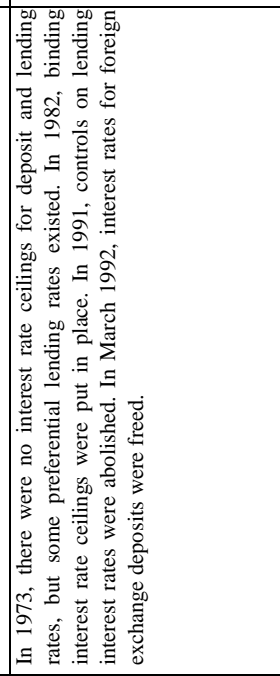 & 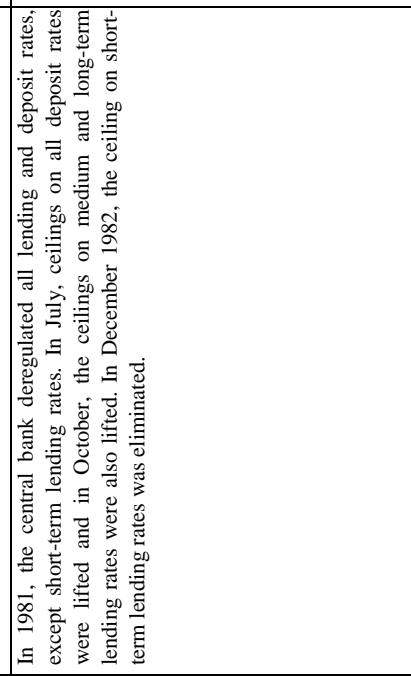 & 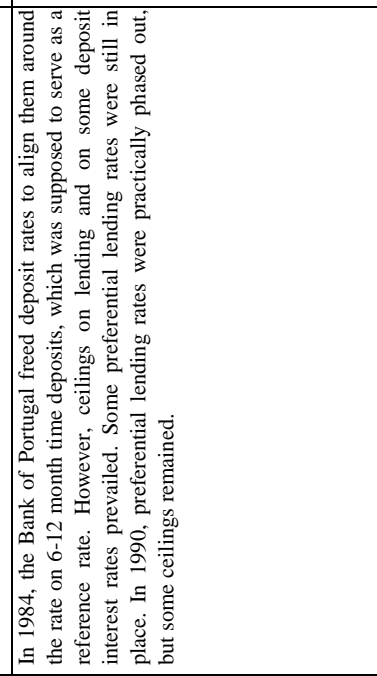 \\
\hline 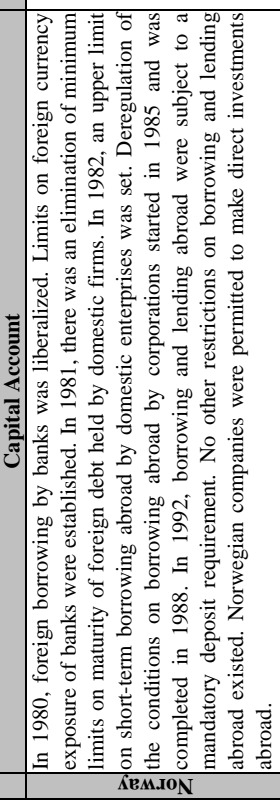 & 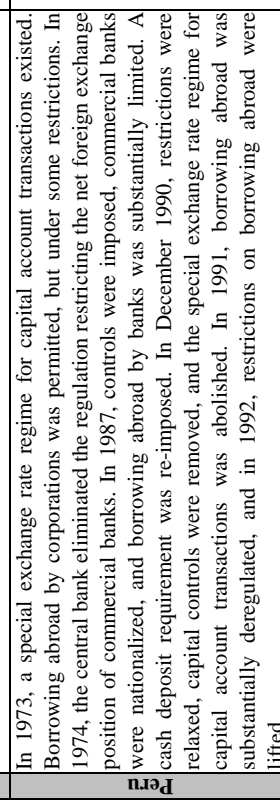 & 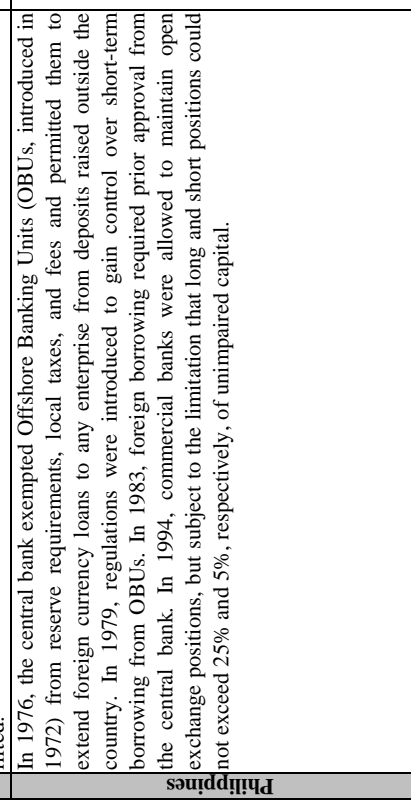 & 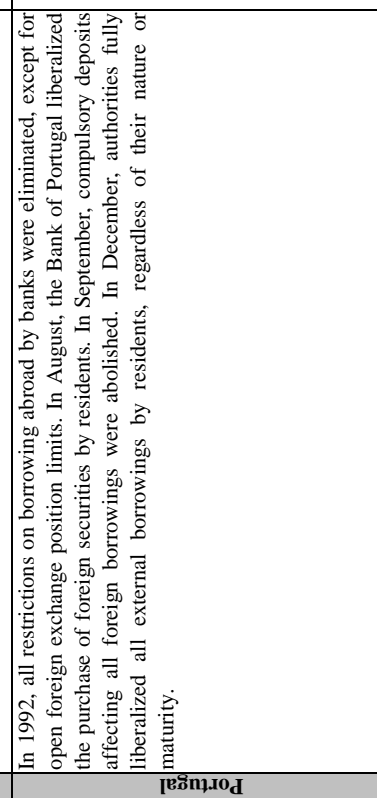 \\
\hline
\end{tabular}




\begin{tabular}{|c|c|c|}
\hline 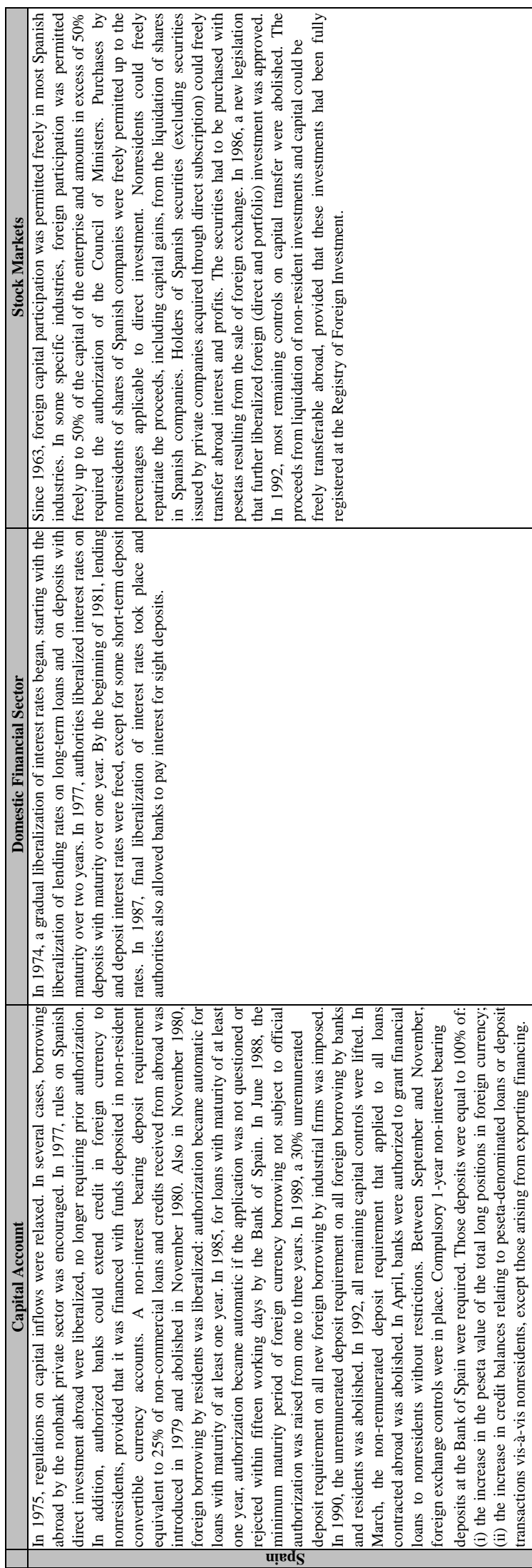 & 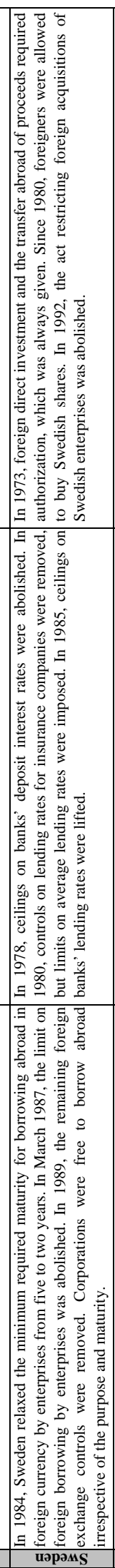 & 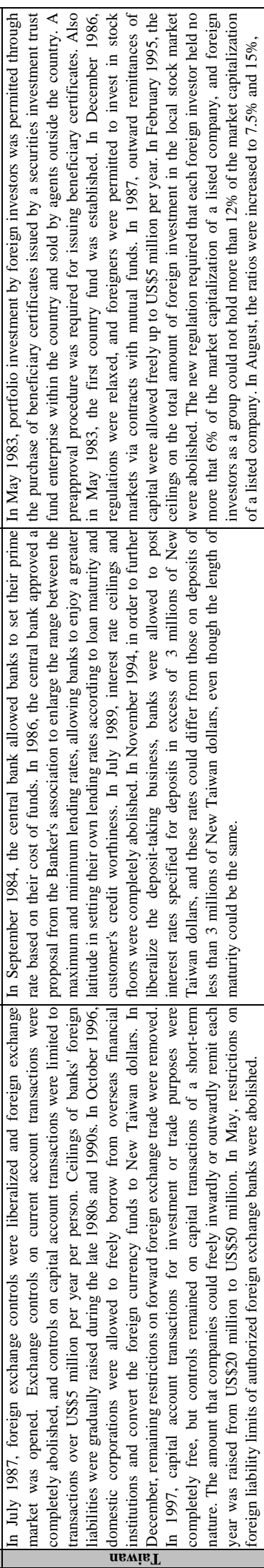 \\
\hline
\end{tabular}




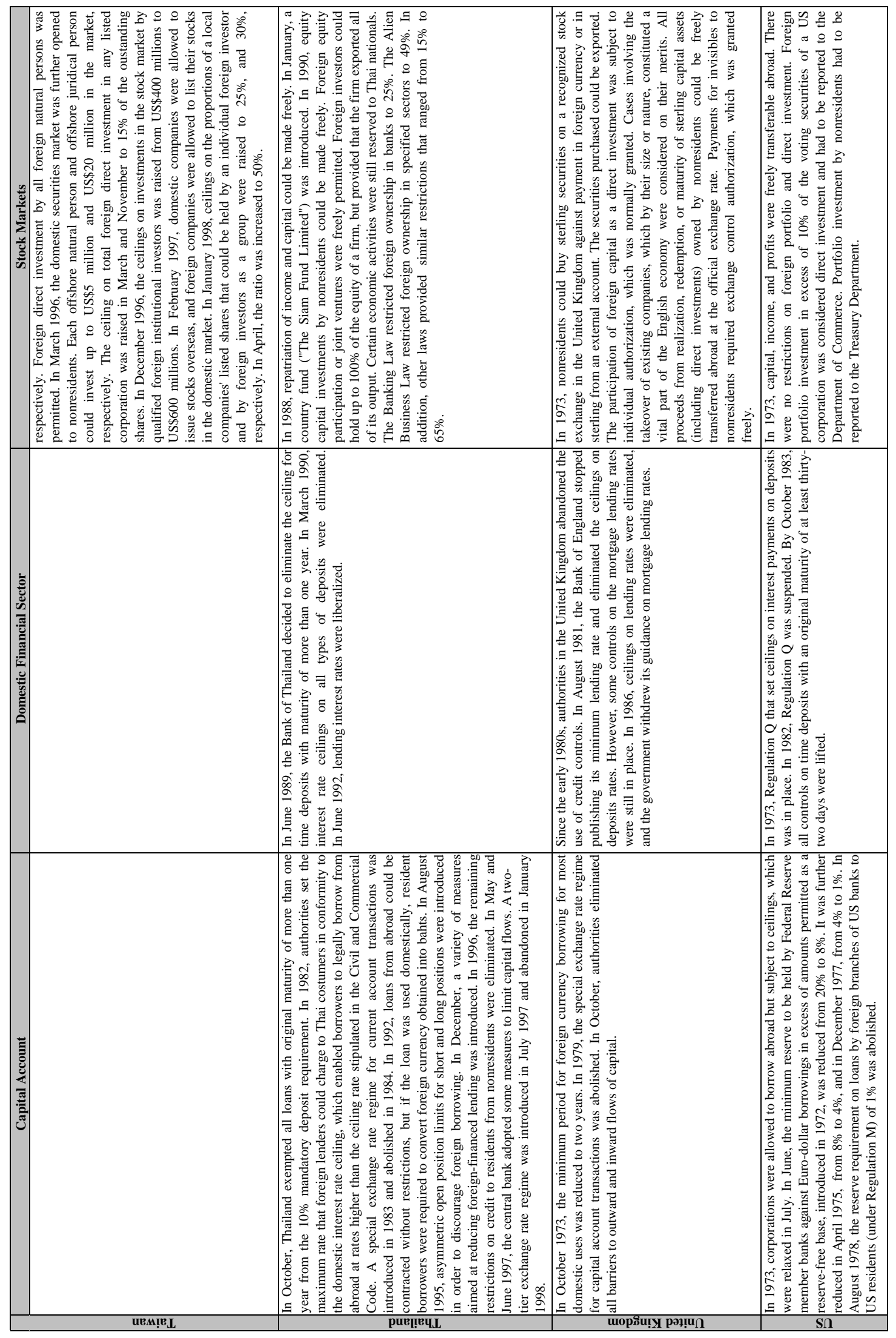




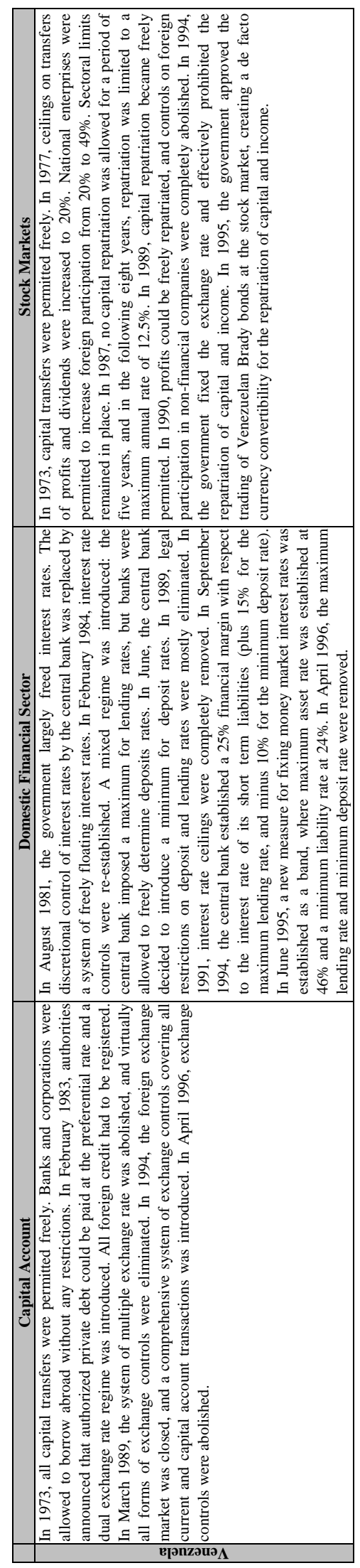




\section{Annex Table 2 \\ References Used to Construct the Chronology of Financial Liberalization}

\section{General References}

Ariyoshi, A., K. Habermeier, B. Laurens, I. ötker-Robe, J. I. Canales-Kriljenko, and A. Kirilenko. 2000. "Capital Controls: Countries Experiences with the Use and Liberalization." IMF (Washington, D.C.) Occasional Paper No.190.

Bekaert, G. and C. Harvey. "Chronology of Economic, Political, and Financial Events in Emerging Markets." www.duke.edu/ charvey/country_risk/chronology.

Bekaert, G., and C. Harvey. 2000. "Foreign Speculators and Emerging Equity Markets." Journal of Finance, 55(2), pp. 565613.

Blondal, S. and H. Christiansen. 1999. "The Recent Experience with Capital Flows to Emerging Market Economies." OECD Economics Department working paper No. 211.

Claessens, S. and M.-W. Rhee. 1993. "The Effect of Equity Barriers on Foreign Investment in Developing Countries." National Bureau of Economic Research (Cambridge, MA) Working Paper No.4579.

Clavijo, S. 1995. "A Survey of Economic Policies and Macroeconomic Performance in Chile and Colombia: 1970-95." IMF (Washington, DC) Working Paper No.139.

Coricelli, F. 1998. "Macroeconomic Policies and the Development of Markets in Transition Economies." Budapest: Central European University Press.

Coricelli, F. 1999. "Financial Market Development and Financial Liberalization in Economies in Transition: Tales of Failure and Success." Paper presented at the Workshop on Financial Liberalization: How Far? How Fast? Development Research Group, The World Bank, March 18-19.

Dooley, M. and I. Shin. 2000. "Private Inflows When Crises Are Anticipated: A Case Study of Korea." National Bureau of Economic Research (Cambridge, MA) Working Paper No.7992.

Drees, B. and C. Pazarbasioglu. 1995. "The Nordic Banking Crises: Pitfalls in Financial Liberalization?" IMF (Washington, DC) Working Paper No.61.

Eichengreen, B. and M. Mussa. 1998. "Capital Account Liberalization: Theoretical and Practical Aspects." IMF (Washington, DC) Occasional Paper No.172.

Galbis, V. 1993. "High Real Interest Rates under Financial Liberalization, Is There a Problem?" IMF (Washington, DC) Working Paper No.7.

Glick, R. and M. Hutchison. 2000. "Capital Controls and Exchange Rate Instability in Developing Economies." Pacific Basin working paper series PB00-05, pp. 1-20, Federal Reserve Bank of San Francisco, Economic Research Department, Center for Pacific Basin Monetary and Economic Studies.

Huang, B.-N. and C.-W. Yang. 2000. "The Impact of Financial Liberalization on Stock Price Volatility in Emerging Markets." Journal of Comparative Economics, 28(2), pp. 321-39.

International Finance Corporation. "Emerging Markets Database." Washington, D.C.: IFC, various issues.

International Monetary Fund. "Exchange Arrangements and Restrictions." Washington, D.C.: IMF, various issues.

International Monetary Fund. "Recent Economic Developments." Washington, D.C.: IMF, various issues.

Johnston, B., S. Darbar, and C. Echeverría. 1997. "Sequencing Capital Account Liberalization: Lessons from the Experiences in Chile, Indonesia, Korea, and Thailand." IMF (Washington, DC) Working Paper No.157.

Kunt, A. D. and E. Detragiache. 1998. "Financial Liberalization and Financial Fragility." IMF (Washington, DC) Working Paper No.83.

Mehrez, G. and D. Kaufman. 2000. "Transparency, Liberalization, and Banking Crises." World Bank (Washington, DC) Policy Research Working Paper No.2286.

OECD. "OECD Economic Surveys." Paris: OECD, various issues. 
Reinhart, C. and V. Reinhart. 1997. "Some Lessons for Policy Makers Dealing with the Mixed Blessing of Capital Inflows." Mimeo.

Reinhart, C. and T. Smith. 1995. "Capital Controls: Concepts and Experiences." Mimeo.

Reinhart, C. and T. Smith. 1997. "Too Much of a Good Thing: the Macroeconomic Effects of Taxing Capital Inflows." Mimeo.

Savastano, M. 1992. "Dollarization in Latin America: Gresham's Law in Reverse?" IMF (Washington, DC) Staff Papers No. 39, pp. 518-44.

Savastano, M. 1996. "Dollarization in Latin America: Recent Evidence and Some Policy Issues." IMF (Washington, DC) Working Papers No.4.

Sundarajan, V. and T. Baliño. 1991. "Issues in Recent Banking Crises." in V. Sundarajan and T. Baliño, eds.: Banking Crises: Cases and Issues, Washington, D.C.: IMF.

Williamson, J. and M. Mahar. 1998. "A Review of Financial Liberalization." South Asia Discussion Paper, Report No. IDP171, The World Bank.

Wyplosz, C. 1999. "Financial Restraints and Liberalization in Postwar Europe." Paper presented at the Workshop on Financial Liberalization: How Far? How Fast? Development Research Group, The World Bank, March 18-19.

\section{Country-Specific References}

\section{Argentina}

Baliño, T. 1990. "The Argentine Banking Crisis of 1980." in V. Sundarajan and T. Baliño, eds.: Banking Crises: Cases and Issues, Washington, D.C.: IMF.

Choueiri, N. and G. Kaminsky. 1999. "Has the Nature of Crises Changed? A Quarter Century of Currency Crises in Argentina." IMF (Washington, DC) Working Paper No.152.

Gaba, E. 1981. "La Reforma Financiera Argentina: Lecciones de una Experiencia." Ensayos Economicos No.19, Buenos Aires, Banco Central de la República Argentina.

García Herrero, A. 1997. "Banking Crises in Latin America in the 1990s: Lessons from Argentina, Paraguay, and Venezuela." IMF (Washington, DC) Working Paper No.140.

Williamson, J. and M. Mahar. 1998. "A Review of Financial Liberalization." South Asia Discussion Paper, Report No. IDP171, The World Bank.

\section{Brazil}

Banco Central do Brasil. "Boletim Mensal." Brasilia: Central Bank, various issues.

Cardoso, E. and I. Goldfajn. 1998. "Capital Flows to Brazil: the Endogeneity of Capital Controls." IMF (Washington, DC) Staff Paper No.45, pp.161-202.

Edwards, A. 1988. "Brazil: A Guide to the Structure, Development, and Regulation of the Financial Services." London: Economist Intelligence Unit.

Garcia, M. and M. V. Valpassos. 2000. "Capital Flows, Capital Controls, and Currency Crisis: the Case of Brazil in the Nineties." In Larrain, F., eds. . Capital flows, capital controls \& currency crises: Latin America in the 1990s.

\section{Canada}

Minister of Supply and Services. "Canada Yearbook." Quebec: Minister of Supply and Services, various issues.

von Furstenburg, G. M (ed.). 1997. The Banking and Financial Structure in the NAFTA Countries and Chile. Boston: Kluwer Academic Publishers. 


\section{Chile}

Bekaert, G., and C. Harvey. 2000. "Foreign Speculators and Emerging Equity Markets." Journal of Finance, 55(2), pp. 565613.

Central Bank of Chile. "Annual Report." Santiago: Central Bank, various issues.

Edwards, S. and A. Cox-Edwards. 1987. Monetarism and Liberalization: the Chilean Experiment. Cambridge, Massachusetts: Ballinger Publishing Co.

Edwards, S. 1999. "How Effective are Capital Controls?" National Bureau of Economic Research (Cambridge, MA) Working Paper No.7413.

Johnston, B., S. Darbar, and C. Echeverría. 1997. "Sequencing Capital Account Liberalization: Lessons from the Experiences in Chile, Indonesia, Korea, and Thailand." IMF (Washington, DC) Working Paper No.157.

Nadal-De Simone, F. and P. Sorsa. 1999. "A Review of Capital Account Restrictions in Chile in the 1990s." IMF (Washington, DC) Working Paper No.52.

Velasco, A. 1999. "Liberalization, Crisis, Intervention: The Chilean Financial System, 1975-85." in V. Sundarajan and T. Baliño, eds.: Banking Crises: Cases and Issues, Washington, D.C.: IMF.

von Furstenburg, G. M (ed.). 1997. The Banking and Financial Structure in the NAFTA Countries and Chile. Boston: Kluwer Academic Publishers.

Williamson, J. and M. Mahar. 1998. "A Review of Financial Liberalization." South Asia Discussion Paper, Report No. IDP171, The World Bank.

World Bank. 1979. Chile: An Economy in Transition. Washington, D.C.: World Bank.

\section{Colombia}

Barajas, A., R. Steiner, and N. Salazar. 1999. "Interest Sspreads in Banking in Colombia 1974-96." IMF (Washington, DC) Staff Papers 46(2), pp. 196-224.

Barrera, F. and M. Cardenas. 1997. "On the Effectiveness of Capital Controls: the Experience of Colombia During the 1990s." Special issue: 8th Inter-American Seminar on Economics, Journal of Development Economics, 54(1), pp.1-187.

Central Bank of Colombia. "Annual Report." Bogota: Central Bank, various issues.

Central Bank of Colombia. 1999. "Report to the Congress."

World Bank. 1984. "Colombia: Economic Development and Policy under Changing Conditions." Washington, D.C.: World Bank.

\section{Denmark}

Danmarks Nationalbank. "Report and Accounts." Copenhagen: Central Bank, various issues.

\section{Finland}

Bank of Finland. "Bulletin." Helsinki: Central Bank, various issues.

Bank of Finland. "Yearbook." Helsinki: Central Bank, various issues.

Drees, B. and C. Pazarbasioglu. 1995. "The Nordic Banking Crises: Pitfalls in Financial Liberalization?" IMF (Washington, DC) Working Paper No.61.

Ministry of Finance. "Supplement to the Budget Proposal - Economic Surveys." Helsinki: Ministry of Finance, various issues. 


\section{Hong Kong}

Hong Kong General Chamber of Commerce. 2001. "Economic Comments: More Rate Cuts Expected from Hong Kong." August 22, 2001.

Census and Statistics Department. "Hong Kong Monthly Digest of Statistics." Hong Kong: Census and Statistics Department, various issues.

Chan, A. K. K., Y. K. Ho, R. H. Scott, and K. A. Wong (eds.). 1991. The Hong Kong Financial System. Hong Kong; New York: Oxford University Press.

Ho, Y. K., R. H. Scott, and K. A. Wong (eds.). 1986. Hong Kong's Financial Institutions and Markets. Hong Kong; New York: Oxford University Press.

Hong Kong Government Secretariat. "Economic Background." Hong Kong: Hong Kong Government Secretariat, various issues.

Hong Kong Monetary Authority. "Annual Report." Hong Kong: HKMA, various issues.

Kwan, S. 2000. Impact of Deposit Rate Deregulation in Hong Kong on the Market Value of Commercial Banks. Hong Kong Institute for Monetary Research and Federal Reserve Bank of San Francisco.

The Economist Intelligence Unit. 1998. "Country Report Hong Kong." November 16, 1998.

The Government Publications Centre. "Hong Kong: A New Era." Hong Kong: The Government Publications Centre, various

\section{Indonesia}

Bank Indonesia. "Report for the Financial Year." Jakarta: Central Bank, various issues.

Hanson, J. 1999. "Financial Sector Research." Paper presented at the workshop on Financial Liberalization: How Far? How Fast? Development Research Group, The World Bank, March 18-19.

Hill, H. 1996. The Indonesian Economy since 1966. Cambridge: Cambridge University Press.

Montgomery, J. 1996. "The Indonesian Financial System; Its Contribution to Economic Performance, and Key Policy Issues." IMF (Washington, DC) Working Paper No.45.

\section{Italy}

Banca D’Italia. 1977. "Bolletino XXXII no. 2." Roma: Central Bank.

Banca D’Italia. 1992. "Bolletino Economico del Servicio Studi no. 18." Roma: Central Bank.

Banca D’Italia. 1992. "Bolletino Mensile di Statistica, no. 1 Anno 67." Roma: Central Bank.

Banca D’Italia. "Economic Bulletin." Roma: Central Bank, various issues.

\section{Japan}

Bank of Japan. "Monthly Economic Review." Tokyo: Central Bank, various issues.

\section{Korea}

Chinn, M. and W. Maloney. 1996. "Financial and Capital Account Liberalization in the Pacific Basin: Korea and Taiwan During the 1980's." National Bureau of Economic Research (Cambridge, MA) Working Paper No.5814.

Cho, Y. J. 1999. "Financial Crisis of Korea - A Consequence of Unbalanced Liberalization?" Paper presented at the Workshop on Financial Liberalization: How Far? How Fast? Development Research Group, The World Bank, March 18-19.

Cho, D. and Y. Koh. 1996. "Liberalization of Capital Flows in Korea: Big Bang or Gradualism?" National Bureau of Economic Research (Cambridge, MA) Working Paper No.5824. 
Chong, L. 1999. "Asia-Pacific: Regulatory Changes to Foreign Direct Investment." Asia-Pacific Tax Bulletin 5, 267-73, Netherlands: APTB.

\section{Malaysia}

Bank Negara Malaysia. "Annual Report." Malaysia: Central Bank, various issues.

\section{Mexico}

von Furstenburg, G. M (ed.). 1997. The Banking and Financial Structure in the NAFTA Countries and Chile. Boston: Kluwer Academic Publishers.

Bank of Mexico. "Annual Report." Mexico, D.F.: Central Bank, various issues.

Bank of Mexico. "The Mexican Economy." Mexico, D.F.: Central Bank, various issues.

Montes-Negret, F. and L. Landa. 1999. "Financial Sector Reseach." Paper presented at the workshop on Financial Liberalization: How Far? How Fast? Development Research Group, The World Bank, March 18-19.

\section{Norway}

Norges Bank. "Economic Bulletin." Oslo: Central Bank, various issues.

\section{Peru}

Banco Central de Reserva de Perú. "Boletín Mensual." Lima: Central Bank, various issues.

Savastano, M. 1996. "Dollarization in Latin America: Recent Evidence and some Policy Issues." IMF (Washington, DC) Working Paper No.4.

\section{Philippines}

Dohner, R. and P. Intal. 1989. "The Philippines Financial System and the Debt Crisis." in J. Sachs and S. Collins, eds.: Developing Country Debt and Economic Performance 3, Chapter 5, Chicago: University of Chicago Press.

Gochoco-Bautista, M. S. 1999. "The Past Performance of the Philippine Banking Sector and Challenges in the Postcrisis Period." in Rising to the Challenge in Asia: a Study of Financial Markets: vol. 10 - Philippines, Asian Development Bank publications.

Nascimento, J. C. 1990. "Crisis in the Financial Sector and the Authorities' Reaction: the Philippines." in V. Sundararajan and T. Baliño, eds.: Banking Crises: Issues and Experiences, Chapter 4, Washington, D.C.: IMF.

Nasution, A. 1999. "Recent Issues in the Management of Macroeconomic Policies in the Philippines." in Rising to the Challenge in Asia: a Study of Financial Markets: vol. 10 - Philippines, Asian Development Bank publications.

Vos, R. 1997. "Financial Reform, Institutions, and Macroeconomic Adjustment. The Destabilizing Effects of Financial Liberalization in the Philippines, 1970 to 1992." in Gupta, K. L., ed.: Experiences with Financial Liberalization, Chapter 5, Boston: Kluwer Academic Publishers.

\section{Portugal}

Banco do Portugal. "Economic Bulletin Quarterly." Lisboa: Central Bank, various issues.

Bakker, A. 1996. "The Liberalization of Capital Movements in Europe." Netherlands: Kluwer Academics Publishers.

\section{Spain}

Bank of Spain. "Annual Report." Madrid: Central Bank, various issues. 


\section{Sweden}

Drees, B. and C. Pazarbasioglu. 1995. "The Nordic Banking Crises: Pitfalls in Financial Liberalization?" IMF (Washington, DC) Working Paper No.61.

Englund, P. 1990. "Financial Deregulation in Sweden." European Economic Review, 34, 385-93.

Sveriges Riksbanks. "Quarterly Review." Stockholm: Central Bank, various issues.

\section{Taiwan}

Central Bank of China. "Annual Report." Taiwan: Central Bank, various issues.

Chinn, M. and W. Maloney. 1996. "Financial and Capital Account Liberalization in the Pacific Basin: Korea and Taiwan during the 1980's." National Bureau of Economic Research (Cambridge, MA) Working Paper No.5814.

Kuo, C.-H. 1991. International Capital Movements and the Developing World: The Case of Taiwan. New York: Praeger Publishers.

\section{Thailand}

Bank of Thailand. "Thailand Economic Conditions." Bangkok: Central Bank, various issues.

Bank of Thailand. 1980. "Outlook." Bangkok: Central Bank.

Bank of Thailand. "Annual Economic Report." Bangkok: Central Bank, various issues.

Johnston, B. 1991. "Distressed Financial Institutions in Thailand: Structural Weakness, Support Operations, and Economic Consequences." in V. Sundarajan and T. Baliño, eds.: Banking Crises: Cases and Issues, Washington, D. C.: IMF.

Johnston, B., S. Darbar, and C. Echeverría. 1997. "Sequencing Capital Account Liberalization: Lessons from the Experiences in Chile, Indonesia, Korea, and Thailand." IMF (Washington, DC) Working Paper No.157.

\section{United Kingdom}

Bank of England. 1973. "Banking Act Report." London: Central Bank.

\section{United States}

Board of Governors of the Federal Reserve System. 1973. "Annual Report." Washington, D.C.: U.S. Govt. Print Off.

"The Economic Report of the President to the Congress" Washington D.C., 1983.

\section{Venezuela}

Central Bank of Venezuela. "Annual Report." Caracas: Central Bank, various issues.

Central Bank of Venezuela. "Monthly Bulletin." Caracas: Central Bank, various issues.

Central Bank of Venezuela. 1995. "Year-end Economic Review." Caracas: Central Bank.

Central Office of Statistics. 1997. "Statistical Yearbook of Venezuela." Caracas: OCEI. 